University of Chicago Law School

Chicago Unbound

Public Law and Legal Theory Working Papers

Working Papers

2014

\title{
Limiting Political Contributions after Mccutcheon, Citizens United, and SpeechNow
}

Albert W. Alschuler

Follow this and additional works at: https://chicagounbound.uchicago.edu/public_law_and_legal_theory

Part of the Law Commons

Chicago Unbound includes both works in progress and final versions of articles. Please be aware that a more recent version of this article may be available on Chicago Unbound, SSRN or elsewhere.

\section{Recommended Citation}

Albert Alschuler, "Limiting Political Contributions after Mccutcheon, Citizens United, and SpeechNow" (University of Chicago Public Law \& Legal Theory Working Paper No. 485, 2014).

This Working Paper is brought to you for free and open access by the Working Papers at Chicago Unbound. It has been accepted for inclusion in Public Law and Legal Theory Working Papers by an authorized administrator of Chicago Unbound. For more information, please contact unbound@law.uchicago.edu. 


\title{
CHICAGO
}

PUblic LAW AND Legal THEORY WORKING PAPER No. 485

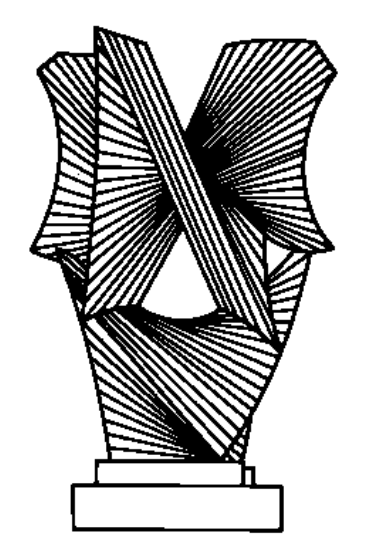

\section{LIMITING POLITICAL CONTRIBUTIONS AFTER MCCUTCHEON,} CITIZENS UNITED, AND SPEECHNOW

Albert W. Alschuler

\author{
THE LAW SCHOOL \\ THE UNIVERSITY OF CHICAGO
}

August 2014

This paper can be downloaded without charge at the Public Law and Legal Theory Working Paper Series:

http://www.law.uchicago.edu/academics/publiclaw/index.html

and The Social Science Research Network Electronic Paper Collection. 


\title{
Limiting Political Contributions AFter MCCUtCheon, Citizens United, AND SPEECHNOW
}

\author{
Albert W. Alschuler
}

\begin{abstract}
The plurality and dissenting opinions in McCutcheon v. FEC seem unreal. These opinions, which considered a series of strategies for circumventing federal limits on contributions to candidates, failed to notice that these limits were no longer breathing. The D.C. Circuit's 2010 decision in SpeechNow.org v. FEC created a far easier way to evade the limits than any of those the Supreme Court discussed. SpeechNow held all limits on contributions to super PACs unconstitutional.

This Article contends that SpeechNow was wrongly decided. It also considers what can be said for and against a bumper sticker's declarations that money is not speech and that corporations are not people. It proposes a framework for evaluating the constitutionality of campaign-finance regulations that differs from the one currently employed by the Supreme Court. And it proposes a legislative scheme of campaign-finance regulation that would effectively limit contributions while respecting the Supreme Court's campaign-finance decisions.
\end{abstract}

\section{TABLE OF CONTENTS}

I. INTRODUCTION: THE ELEPHANT (OR SUPER PACHYDERM) IN THE ROOM................. 3

II. AN OVERVIEW OF THIS ARTICLE ........................................................................ 18

III. Citizens United, SPEECHNow, AND How These DeCisions CHANGED

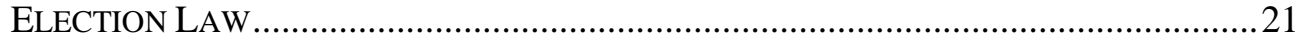

IV. HOW CiTIZENS UNITED AND SPEECHNOW CHANGED ELECTION FINANCING.............31

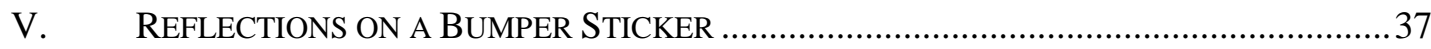

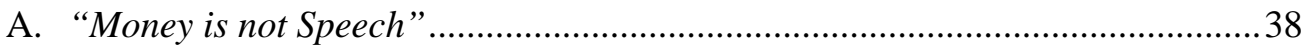

1. Why the Bumper Sticker Gets It Wrong (Mostly) .........................................38

2. Why the Bumper Sticker Gets It Right (Partly) ...........................................39

B. "Corporations are not People".........................................................................4 44

1. Why the Bumper Sticker Gets It Wrong (Mostly)..........................................44

2. Why the Bumper Sticker Gets It Right (Partly).......................................... 49

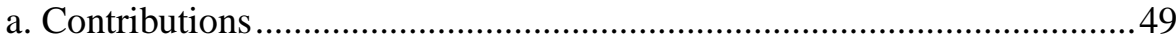

i. Corporate Entities Are Not People........................................................49

ii. Limiting and Equalizing Clout.......................................................... 50

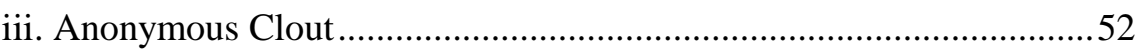

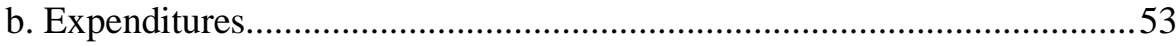

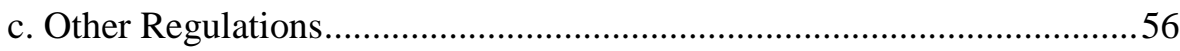

VI. A FRAMEWORK FOR ANALYZING THE CONSTITUTIONALITY OF CAMPAIGN

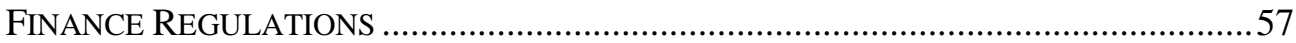

A. John Hart Ely's Variation on a Theme by O’Brien.......................................... 57 


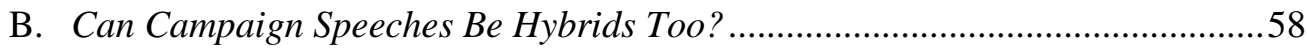

C. How Deeply Did Buckley Bury O’Brien? ......................................................60

VII. A PROPOSED SCHEME OF CAMPAIGN FINANCE REGULATION .................................62

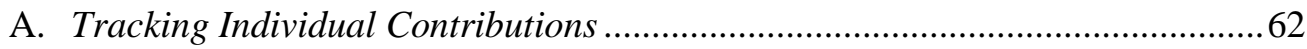

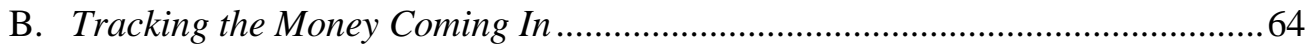

C. Tracking the Money Going Out .......................................................................67

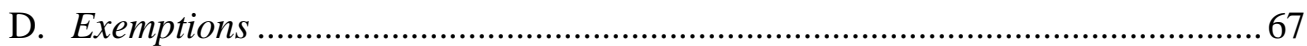

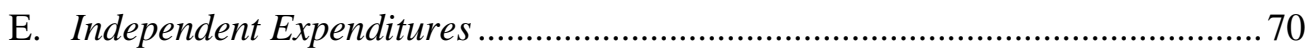

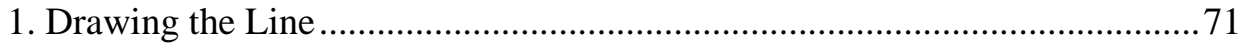

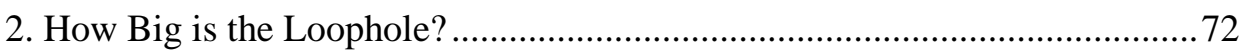

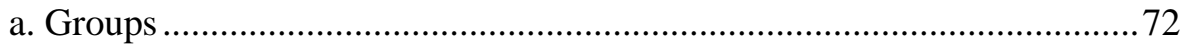

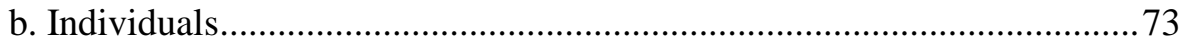

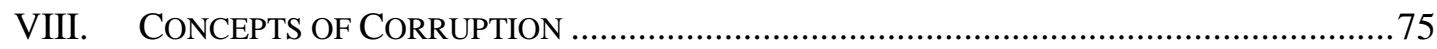

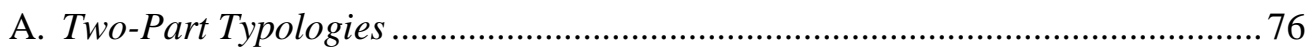

B. Understanding Quid Pro Quo Corruption.......................................................... 78

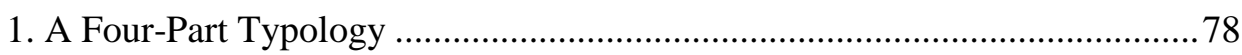

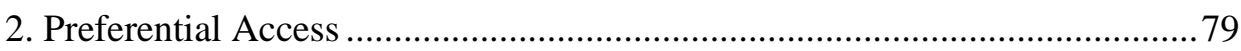

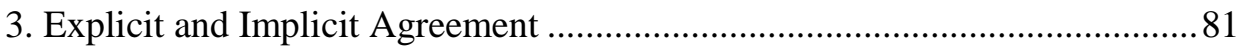

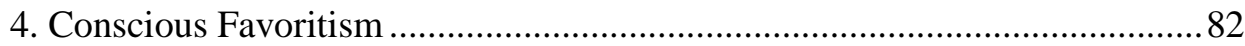

a. The Significance of Buckley v. Valeo...................................................86

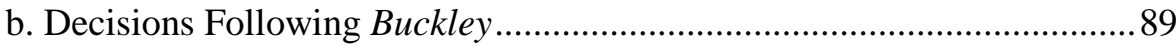

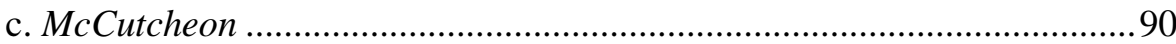

IX. WHY SPEECHNOW ERRED BY STRIKING DOWN LIMITS ON CONTRIBUTIONS

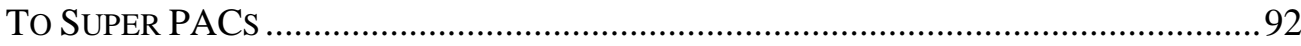

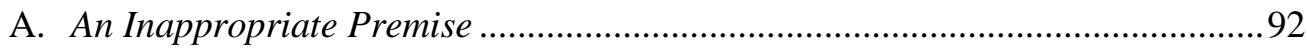

B. A Better Starting Place ................................................................................. 96

X. SUPER PACS AND AgGREgATE CONTRIBUTION LIMITS............................................99

XI. STORY TIME: OTTO’s FRIENDS EXERCISE THEIR RIGHTS........................................ 102

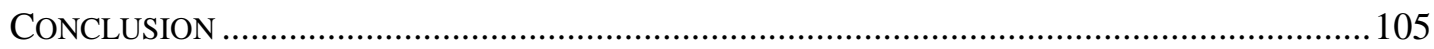

APPENDIX A: HAVE CITIZENS UNITED AND SPEECHNOW ENDED THE GAME? ......................108

APPENDIX B: THE EFFECT OF CAMPAIGN DOLLARS I: STATISTICAL AND

NON-STATISTICAL EVIDENCE ................................................................... 111

APPENDIX C: THE EFFECT OF CAMPAIGN DOLLARS II: THE GENEROSITY OF

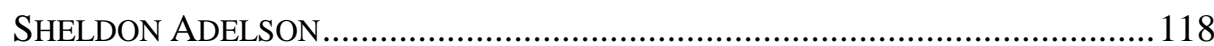

APPENDIX D: THE EFFECT OF CAMPAIGN DOLLARS III: EXECUTIVE CLEMENCY ................124

APPENDIX E: THE EFFECT OF CAMPAIGN DOLLARS IV: THE APPOINTMENT OF

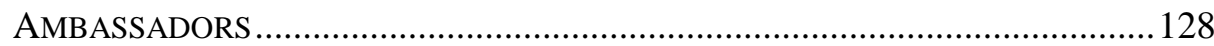

APPENDIX F: PARTISAN ADVANTAGE AND INCUMBENT PROTECTION .................................131 


\title{
Limiting Political Contributions After McCutCheon, Citizens UNITED, AND SPEECHNOW
}

\author{
Albert W. Alschuler ${ }^{*}$
}

\section{INTRODUCTION: THE ELEPHANT (OR SUPER PACHYDERM) IN THE ROOM}

Both the plurality and the dissenting opinions in McCutcheon $v$. $F E C^{1}$ seem unreal. At issue in McCutcheon was the validity of the Bipartisan Campaign Reform Act's (BCRA's) limits on the total amounts a person may contribute to all candidates and political committees during a single election cycle (its "aggregate" contribution limits). The principal issue dividing the Supreme Court was whether, in the absence of these limits, donors could evade the BCRA's "base" limits-its limits on the amount a person may contribute to an individual candidate.

The Court held the aggregate limits unconstitutional by a vote of five to four. In a concurring opinion, Justice Thomas argued that limits on campaign contributions and expenditures should be subject to strict scrutiny - a standard that apparently would invalidate them all. The most significant aspect of the McCutcheon decision, however, may be the willingness of the other eight justices to assume the validity of the base limits and of measures truly necessary to prevent their circumvention.

The four dissenting justices described a series of circumvention strategies they said might follow invalidation of the aggregate limits. These strategies involved multiple political action committees, ${ }^{2}$ party committees, joint fundraising committees, and contributions from one campaign to another. The dissenters and the four justices of the plurality debated at length whether the hypothesized scenarios were realistic, whether they would violate existing laws (a tangle of statutes and regulations described by Justice Scalia at argument as "so intricate that I can't figure [them] out"3), and whether, if the circumvention strategies were not already prohibited, legislation less restrictive than the aggregate contribution limits could block them. A reader of the principal opinions was likely to end up full of admiration for judicial patience that outran

* Julius Kreeger Professor, Emeritus, the University of Chicago Law School. I am grateful to James Phander, Michael Rocca, Sonja Starr, John Stinneford, and Laurence Tribe for valuable comments.

1134 S. Ct. 1434 (2014).

${ }^{2}$ Conventional PACs, not super PACs. The difference will be explained shortly.

3 Transcript of Oral Argument at 17, McCutcheon v. FEC, 134 S. Ct. 1434 (2014) (No. 12-536), available 
his own.

The premises of both the plurality and the dissenting opinions were that contributors would employ the circumvention strategies if only they could and that it would matter whether they did. Both opinions contrived not to notice that the base limits were no longer breathing. Contributors had a far easier way to evade them than any of those the Supreme Court discussed. The corpse lay at the justices' feet, and the Court itself had been widely accused of homicide. But the justices averted their eyes.

A super PAC is a political action committee that does not contribute to the official campaigns of candidates for office but that prepares and places its own advertisements supporting candidates and/or disparaging their opponents. ${ }^{4}$ Two months after the Supreme Court's decision in Citizens United v. FEC ${ }^{5}$ in 2010, the en banc D.C. Circuit held all limit on donations to super PACs unconstitutional in SpeechNow.org v. FEC. ${ }^{6}$ The court offered no defense of the merits of its ruling. It simply said that one broad statement in the Citizens United opinion ("[W]e now conclude that independent expenditures . . . do not give rise to corruption or the appearance of corruption"7) compelled its result.

Before SpeechNow, the Federal Election Commission (FEC) enforced a statute limiting a person's contributions to a PAC of any sort to $\$ 5000$ per year. ${ }^{8}$ On June 12, 2012, however, Sheldon Adelson and his wife Miram exercised the newly recognized right of all Americans to contribute $\$ 10$ million to the super PAC of their choice. They gave these funds to Restore Our Future, an organization supporting the election of Mitt Romney as President. ${ }^{9}$ At the time of their contribution, Sheldon Adelson told friends that he planned to spend at least $\$ 100$ million supporting causes and candidates during the 2012 election cycle. ${ }^{10}$

Adelson's estimate was too low. Although the Adelsons' contributions to official campaigns and super PACs roughly matched the estimate (\$98 million-including an additional \$20 million to Restore Our Future), two Republican fundraisers told the press that they contributed at least \$45 million more to groups that were not required to

${ }^{4}$ See McCutcheon, 134 S. Ct. at 1442 n.2.

${ }^{5} 558$ U.S. 310 (2010).

${ }^{6} 599$ F.3d 686 (D.C. Cir. 2010).

${ }^{7}$ Citizens United, 558 U.S. at 360.

${ }^{8}$ See 2 U.S.C. $\S 441 \mathrm{a}(\mathrm{a})(1)(\mathrm{C})$.

${ }^{9}$ See Alicia Mundy \& Sara Murray, Adelson Gives \$10 Million to Pro-Romney Super PAC, Wall St. J., June 13, 2012, available at http://blogs.wsj.com/washwire/2012/06/13/adelson-gives-10-million-to-pro-romneysuper-pac/.

${ }^{10} I d$. 
identify their contributors. ${ }^{11}$ The amount of the Adelsons' 2012 donations exceeded the entire amount the Republican nominee for President in 2008, John McCain, spent during his general election campaign. ${ }^{12}$ The Adelsons led a list of 95 individuals or couples and 56 organizations that each contributed $\$ 1$ million or more to outside spending groups in 2012. ${ }^{13}$

An independent expenditure group like Restore Our Future may not coordinate its expenditures with those of an official election campaign. ${ }^{14}$ Like many other "candidate-specific" or "alter ego" super PACs, however, Restore Our Future was managed by people close to the candidate it supported. ${ }^{15}$ They included Carl Forti, the political director of Romney's 2008 presidential campaign; Charles Spies, counsel and chief financial officer of the 2008 campaign; and Larry McCarthy, another prominent veteran of Romney's 2008 effort. ${ }^{16}$ These managers might have known without coordination or palaver what expenditures would please Governor Romney. ${ }^{17}$

Candidates may, within limits, raise money for super PACs and may address super PAC gatherings. ${ }^{18}$ In the month before the Adelsons’ initial

11 See Theodoric Meyer, How Much Did Sheldon Adelson Really Spend on Campaign 2012?, PROPUBLICA, Dec. 20, 2012, http://www.propublica.org/article/howmuch-did-sheldon-adelson-really-spend-on-campaign-2012. 501(c)(4) or "dark money" groups are tax-exempt organizations whose earnings are devoted to charitable, educational, or recreational purposes. An IRS regulation seemingly plucked from the air allows these groups to "intervene in political campaigns as long as [their] primary activity is the promotion of social welfare.” INTERNAL REVENUE MANUAL 7.25.4.7; see note infra. Unlike super PACs, 501(c)(4) groups need not reveal the identity of their contributors.

12 See FEC, Press Release: 2008 Presidential Campaign Financial Activity Summarized: Receipts Nearly Double 2004 Total, June 8, 2009, http://www.fec.gov/press/press2009/20090608PresStat.shtml. Because Senator McCain accepted federal funding for his campaign, the amount he could spend was limited. See id. His opponent, Senator Obama, did not accept federal funding, and no future nominee is likely to accept it either.

13 See OpenSecrets.org, 2012 Top Donors to Outside Spending Groups, http://www.opensecrets.org/outsidespending/summ.php?cycle=2012\&disp=D\&type=V \&superonly=N.

$14 \quad$ See 11 CFR $\S \S \quad 109.20-109.23 \quad$ (2009), available at http://www.fec.gov/law/cfr/cfr_2009.pdf.

15 See Mike McIntire \& Michael Luo, Fine Line Between "Super PACs” and Campaigns, N.Y. TimeS, Feb. 25, 2012, at A1.

16 See Rachael Marcus, PAC Profile: Restore Our Future, The Center for Public Integrity, http://www.publicintegrity.org/node/7977/. McCarthy's chief claim to fame was that, in 1988, he devised the Willie Horton ad for candidate George H. W. Bush. Id.

${ }^{17}$ Priorities USA, President Obama's alter ego super PAC, was similarly directed by people close to him.

18 See FEC Advisory Opinion AO 2011-12 (June 30, 2011), available at 
\$10 million contribution, Sheldon Adelson met with Governor Romney and reportedly sought "assurance that Romney would support Israel more strongly than President Obama has.”19

Adelson, a Las Vegas casino owner, has an agenda. It includes opposition to a two-state solution to the Israeli-Palestinian conflict and positions on a number of issues that directly affect Adelson's business interests. An appendix to this Article ("The Effect of Campaign Dollars II: The Generosity of Sheldon Adelson”) describes some of these interests.

Without prearrangement or coordination, the managers of a super PAC may recognize an effective division of labor. Their job is to attack an opponent while the favored candidate takes a higher road. Independent expenditure groups have been called "the attack dogs and provocateurs of modern politics." ${ }^{20}$ A report shortly before the 2012 election declared:

Republican super PACs have spent three times as much opposing Obama as they have backing Romney, \$46 million to $\$ 14$ million. The gap is even larger on the Democratic side (though the absolute numbers are much smaller), where there's been nearly $\$ 28$ million in attacks on Romney and only a little more than \$3 million in favor of Obama. . . . Republican super PACs spent more trying to sink Mitt Romney during the Republican primaries than the president's Democratic allies have spent in favor of [the President] during the entire campaign, $\$ 4.7$ million to $\$ 3.2$ million. $^{21}$

Once SpeechNow unleashed super PAC contributions, the pretense

http://www.fec.gov/pages/fecrecord/august2011/ao2011-12.shtml. Although, after SpeechNow, an individual may give unlimited amounts to a super PAC, a candidate may not request a donation exceeding the amount this individual could give to a conventional PAC. Id. For a useful description of the very strange law on this subject, see Venable LLP Political Practice Group, Candidates and Super PACs: A Complicated Relationship (Feb. 13, 2013), http://www.politicallawbriefing.com/myblog/2013/02/candidates-and-super-pacs-a-complicated-relationship.html.

${ }^{19}$ See Callum Borchers, Romney PAC Gets \$10M Gift: Casino Magnate May Give $\$ 100 M$ in Election, Boston GloBe, June 14, 2012, at A10.

${ }^{20}$ See Jeremy W. Peters, Conservative "Super PACs" Synchronize Their Messages, N.Y. TimES, Sept. 25, 2012, at A10 ("Independent groups have long been the attack dogs and provocateurs of modern politics. The ads they produce-about a convict on furlough named Willie Horton or Swift Boat veterans-have become synonymous with dirty politics.”).

${ }^{21}$ David A. Graham, The Incredible Negative Spending of Super PACs, THE ATLANTIC, Oct. 15, 2012, http://www.theatlantic.com/politics/archive/2012/10/theincredible-negative-spending-of-super-pacs-in-1-chart/263643/. 
that the BCRA's base and aggregate limits served a useful purpose became absurd. These limits do more harm than good. Restricting contributions to official election campaigns while permitting unlimited contributions to super PACs does not limit the amount an individual may contribute to an electoral effort; it merely channels funds to less responsible and more destructive speakers. Contributions to a candidate's official campaign currently are capped at $\$ 2,600$ per election $(\$ 5,200$ total for both primary and general elections) $)^{22}$ while an off-leash satellite campaign may accept \$10,000, \$100,000, \$1 million, and \$10 million contributions.

To consumers of commercials on couches, super PACs are faceless groups with noble names like Restore Our Future, Priorities USA, and Making a Better Tomorrow, Tomorrow. ${ }^{23}$ When one of these groups goes too far (for example by telling demonstrable falsehoods), a candidate can deplore its conduct and accurately insist, “'Twasn't me.” Unlike the candidates they support, super PACs typically vanish once an election is over.

SpeechNow has degraded rather than enhanced the quality of electoral advocacy. The flood of attack ads has contributed to the nation's cynicism about politics, a cynicism that runs deep among young people. ${ }^{24}$ Even without the SpeechNow decision, running for office would mean entering a world of sharpened knives, but SpeechNow has made the warfare worse. ${ }^{25}$ Michael McConnell comments, "I am skeptical of any

22 See 2 U.S.C. § 441a(a)(1); 78 Fed. Reg. 8532 (2013).

23 The names are not fictitious. In 2012, the first super PAC named supported Mitt Romney; the second, Barack Obama; and the third, Steven Colbert.

24 See Institute of Politics, HARVARD University, SURVEY OF Young Americans’ Attitudes Toward Politics And Public SERvice (23d edition 2013), http://www.iop.harvard.edu/sites/default/files_new/spring_poll_13_Exec_Summary.pdf ("At no time since President Obama was elected in 2008 have we reported less trust, more cynicism and more partisanship among our nation's youngest voters.”).

25 New Jersey's elections for state offices in 2013 provide an illustration. These elections followed a consent decree that, echoing SpeechNow, forbade the enforcement of state limits on super PAC contributions. See Fund for Jobs, Growth, \& Sec. v. New Jersey Election Law Enforcement Comm’n, No. 13-CV-02177-MAS-LHG (D.N.J. July 11, 2013). Outside spending then reached $\$ 35$ million, twice what it had been in the year of the immediately preceding gubernatorial election, 2009. See Nicholas Confessore, Big Money Flows in New Jersey Races to Thwart Christie Agenda, N.Y. Times, Nov. 4, 2013, at A1. One super PAC spent \$2 million to influence a single state senate race, all of it apparently devoted to broadcasting an advertisement in which an ominous voice declared that a candidate had been "prohibited from practicing law in New Jersey.” The voice did not mention that the candidate's "prohibition” was brief and rested on his failure to pay an annual registration fee on time. Id.

The North Carolina Supreme Court held in State v. Bowdich, 700 S.E.2d 1 (N.C. 2010), that retroactively requiring people convicted of sex offenses to wear large ankle- 
governmental effort to police campaign speech to make it less negative, vitriolic, or immoderate, but there is little to be said for laws that exacerbate these tendencies."26

Allowing unlimited contributions to feral attack dogs while limiting contributions to candidates themselves is schizophrenic. No sane legislator would vote in favor of this regime, and no legislator ever has. America has this topsy-turvy regime because the D.C. Circuit (or the Supreme Court or the two courts together) held that the First Amendment requires it.

The thought that the Constitution requires it, however, looks crazy too. Just as only a loopy legislator could vote in favor of America's current system of campaign finance, only a cracked court could confront the question afresh and conclude that a \$3000 contribution to Mitt Romney's presidential campaign may be prohibited because it is corrupting while a $\$ 10$ million contribution to Restore Our Future is protected because it "does not give rise to corruption or the appearance of corruption.” 27 No single court has taken full responsibility for the

bracelet transmitters and visible GPS tracking devices, to spend six hours per day recharging these devices, and to submit to electronic monitoring of their movements, in some cases for the rest of their lives, was non-punitive and did not violate the ex post facto clause. Justice Robin Hudson and two other justices dissented. When Justice Hudson ran for reelection four years later, a group called Justice for All NC sponsored television advertisements accusing her of "sid[ing] with the predators." This group, which listed a mailbox in a U.P.S. store as its headquarters, had received $\$ 650,000$ from a Washington, D.C., super PAC funded primarily by businesses like Blue Cross/Blue Shield, Koch Industries, and the Las Vegas Sands Corporation. See OpenSecrets.org, Republican State Leadership Committee Contributors, http://www.opensecrets.org/527s/527cmtedetail_contribs.php?ein=050532524\&cycle=2 $\underline{014}$.

Six former justices of the North Carolina Supreme Court called the attack on Justice Hudson false and disgusting, and the justice's principal opponent disavowed it, saying "I will always run a positive effort." A commentator observed, "[S]pecial interest money . . . often goes toward ads attacking judges' criminal records, even when the interest group is focused on business interests or other unrelated issues.” The amount Justice Hudson was able to raise to respond to the advertisement fell far short of the amount spent broadcasting it. See Erik Eckholm, Outside Spending Enters Arena of Judicial Races, N.Y. Times, May 5, 2014, at A12.

Television viewers have seen innumerable advertisements like the ones just described. As both McCutcheon and Citizens United observed, "[T] 'has its fullest and most urgent application precisely to the conduct of campaigns for political office.”' McCutcheon, 134 S. Ct. at 1441 (quoting Monitor Patriot Co. v. Roy, 401 U.S. 265, 272 (1971)); Citizens United, 558 U.S. at 339 (same).

${ }^{26}$ Michael W. McConnell, Reconsidering Citizens United as a Press Clause Case, 123 YALE L.J. 412, 455 (2013).

${ }^{27}$ Citizens United used the quoted language to describe super PAC expenditures, see 558 U.S. at 360, but SpeechNow concluded that this language applied to super PAC 
constitutional decision that produced America's Dickensian system of campaign finance.

As best I can tell, no supporter of the BCRA has said out loud that it would be better to strike down the statute's base limits than to retain them as a device for channeling funds to super PACs. But I just said it. Rather than keep the BCRA on life support, the Supreme Court would do better to pull the plug, overrule its long line of precedents upholding contribution limits, and afford the statute a decent burial. Justice Thomas's concurring opinion in McCutcheon referred to Buckley v. Valeo $^{28}$ the 1976 decision that first upheld base and aggregate contribution limits, and said, "What remains of Buckley is a rule without a rationale."29

SpeechNow left no way to go but up. McCutcheon in fact improved federal campaign financing a bit by permitting major contributors to channel a larger portion of their donations to candidates and political parties rather than super PACs. ${ }^{30}$ Rather than acknowledge that the BCRA's contribution limits died in 2010, however, the supporters of campaign finance regulation sounded the customary trumpets. "[T]oday's decision eviscerates our Nation's campaign finance laws," the McCutcheon dissenters cried. ${ }^{31}$ An orchestra of journalists, commentators, and fundraisers for politicians denouncing the decision echoed this theme. ${ }^{32}$

The dissent did not give super PACs contributions and expenditures even a glance, and the plurality adverted to them only in a footnote-one that might have led an uninitiated reader to the erroneous view that circumvention by super PAC is part of the statutory scheme rather than the result of dubious constitutional rulings:

A PAC is a business, labor, or interest group that raises or spends money in connection with a federal election, in some

contributions as well.

${ }^{28} 424$ U.S. 1 (1976).

${ }^{29}$ McCutcheon, 134 S. Ct. at 1462 (Thomas, J., concurring).

${ }^{30}$ See Nathaniel Persily, Bringing Big Money Out of the Shadows, N.Y. TIMEs, April 3, 2014, http://www.nytimes.com/2014/04/03/opinion/bringing-big-money-out-ofthe-shadows.html.

${ }^{31}$ McCutcheon, 134 S. Ct. at 1465 (Breyer, J., dissenting).

32 See, e.g., Robert Reich, McCutcheon, and the Vicious Cycle of Concentrated Wealth and Political Power, April 3, 2014, at http://robertreich.org (declaring that the "shameful" McCutcheon decision "effectively eviscerate[s] campaign finance laws"); Linda Greenhouse, An Indecent Burial, N.Y. TIMES, April 16, 2014, http://www.nytimes.com/2014/04/17/opinion/an-indecent-burial.html (declaring that McCutcheon threw the post-Watergate system of campaign-finance regulation "out the window”). 
cases by contributing to candidates. A so-called "Super PAC" is a PAC that makes only independent expenditures and cannot contribute to candidates. The base and aggregate limits govern contributions to traditional PACs, but not to independent expenditure PACs. See SpeechNow.org $v$. Federal Election Comm'n . . . . ${ }^{33}$

During the argument in McCutcheon, however, four Supreme Court justices-Ginsburg, Kennedy, Breyer, and Scalia-pointed to the elephant in the room. Each of these justices asked whether super PAC contributions and expenditures hadn't made the BCRA's aggregate limits pointless or worse. $^{34}$ Justice Scalia, for example, asked Solicitor General Verrilli, “[I]sn't the consequence of - of this particular provision to sap the vitality of political parties and to encourage . . . drive-by PACs for each election?" Verrilli managed almost to complete a sentence-one that included the words “I think the answer is we don't know one way or

${ }^{33}$ McCutcheon, 134 S. Ct. at 1442 n.2.

34 Transcript of oral argument, supra note , at 20 (Scalia, J., noting that "much of the money that used to go to [political parties] now goes to [super] PACs" and that "the consequence . . . has been very severe with respect to national political parties”), 30 (Scalia, J., suggesting that if donating the entire \$3.7 million an individual could give to all federal candidates, parties, and conventional PACs in the absence of the aggregate limits poses "the evil of big money," so does giving the same amount to an independent PAC), 31 (Scalia, J., declaring, “[B]ig money can be in politics. The thing is you can't give it to the Republican Party or the Democratic Party, but you can start your own PAC. That's perfectly good. I'm not sure that's a benefit to our political system.”), 33 (Breyer, J., declaring, “And now you say the person can do the same thing anyway; just call it independent. And what the independent does, he can spend 40 million. He can spend 50 million. And all that does is sort of mix up the messages because the parties can't control it. Now, that's, I think the question that's being asked. And I think that is a very serious question. . . . Is it true? So what? What are we supposed to do?”), 33 (Kennedy, J., following Justice Breyer's question with the statement, “And I have the same question. You have two - two persons. One person gives an amount to a candidate that's limited. The other takes out ads, uncoordinated, just all on his own, costing $\$ 500,000$. Don't you think that second person has more access to the candidate who'swhen the candidate is successful, than the first?”), 42-43 (Ginsburg, J., suggesting that an aggregate limit "drives contributions toward the PACs and away from the parties, that money-without these limits, they money would flow to the candidate, to the party organization, but now, instead, it's going to the PACs. What is your response to that?"), 43 (Scalia, J., initiating the dialogue with the Solicitor General that is described in the text immediately following this footnote), 51-52 (Scalia, J., calling it "fanciful to think that the sense of gratitude that an individual Senator or Congressman is going to feel because of a substantial contribution to the Republican National Committee or Democratic National Committee is any greater than the sense of gratitude that the Senator or Congressman will feel to a PAC which is spending enormous amount of money in his district”). 
the other”- -before Justice Scalia interjected, “I think we do.”35

There seemed to be no good answer to the justices' queries. The solicitor general said things like, "I'm not here to debate the question of whether the Court's jurisprudence is correct with respect to the risk of corruption from independent expenditures," 36 and "Well, the-we take the constitutional First Amendment framework of this Court's decisions as a given. The Court has-the Court has determined that independent expenditures do not present a risk of quid pro quo corruption . . . .”37 Translated into English, these responses seemed to say, "Weren't you guys the ones who started this charade?”

One commentator noted Justice Scalia's questions to the solicitor general and accused the justice of chutzpah_- “"that quality enshrined in a man who, having killed his mother and father, throws himself on the mercy of the court because he is an orphan."'38 Justice Scalia and the other justices of the Citizens United majority had created the super PAC, and to point to this PACman's gobbling up of the BCRA as a reason for dismantling the statute further took nerve. It was as though, some years after McCutcheon, the dissenters' predictions of circumvention had proven accurate and the plurality's contrary predictions had proven incorrect-and the plurality then had pointed to the ease of circumvention as a reason for striking the limits down. ${ }^{39}$ The comedian Jon Stewart played portions of the McCutcheon argument on The Daily Show and made the same point. ${ }^{40}$ As the argument played, the screen showed what appeared to be a courtroom sketch of the justices on the bench smoking from a hookah.

Perhaps the plurality opinion in McCutcheon ignored the super PAC elephant because pointing to it as the justices had at argument would have brought further charges of chutzpah. But pretending the elephant wasn't there did not make either the plurality opinion or the dissenting opinion stronger. Rather than plead for mercy as an orphan, the killer

${ }^{35} I d$. at 43 .

${ }^{36} I d$. at 52.

${ }^{37} I d$. at 43.

${ }^{38}$ Garrett Epps, How Close Will the Supreme Court Get to Ending Campaign Finance Laws?, THE ATLANTIC, Oct. 8, 2013, http://www.theatlantic.com/politics/archive/2013/10/how-close-will-the-supreme-courtget-to-ending-campaign-finance-laws/280401/ (quoting Leo Rosten's definition of chutzpah).

${ }^{39}$ See Joe Patrick, McCutcheon Oral Argument: Or, Justice Scalia Explains How \$3.5 Million Isn't That Much Money, ABOve THE LAW, Oct. 9, 2013, http://abovethelaw.com/2013/10/mccutcheon-oral-argument-or-justice-scalia-explainshow-3-5-million-isnt-that-much-money/.

${ }^{40}$ See Donors Unchained, The Daily Show with Jon STEWART, April 3, 2014, at http://thedailyshow.cc.com/videos/74yxyf/donors-unchained. 
seemed to be insisting that his parents were alive and needed his care. When Solicitor General Verrilli indicated that super PAC circumvention was a product of the Court's campaign finance jurisprudence, Justice Scalia had an accurate, if somewhat chilling, response: "It is what it is, though." 41 The justice might have added, "Just look at that elephant we brought in."

Many observers predict that the Supreme Court will end the irrationality of limiting contributions to candidates while permitting unlimited contributions to satellite campaigns by striking down the limits on contributions to candidates. This Article, however, argues for the opposite resolution-rejecting the SpeechNow decision and upholding the BCRA's limits on contributions to super PACs.

Until now, SpeechNow seems to have escaped criticism. Even commentators who deplore unlimited super PAC contributions accept the D.C. Circuit's judgment that this consequence flows inescapably from Citizens United. ${ }^{42}$ Michael Kang, for example, declares that Citizens United "utterly removed room for argument about Super Pacs"43 and "made SpeechNow an easy case with only one possible outcome." 44

All nine members of the en banc D.C. Circuit (including the three appointed by Democrats) joined the SpeechNow opinion. Five other federal courts of appeals have since endorsed the D.C. Circuit's ruling, ${ }^{45}$ and one court of appeals had made a similar decision prior to SpeechNow. ${ }^{46}$ The Supreme Court declined to review SpeechNow, ${ }^{47}$ and the FEC acquiesced in the D.C. Circuit's ruling. ${ }^{48}$ This Article will swim against the tide and fill a large gap in the literature.

${ }^{41}$ Transcript of oral argument, supra note, at 52.

${ }^{42}$ Hostility to the Citizens United decision may have contributed to the willingness of some commentators to give the D.C. Circuit a pass.

${ }^{43}$ Michael S. Kang, The Year of the Super PAC, 81 GEO. WASH. L. REV. 1902, 1912 (2013).

${ }^{44} \mathrm{Id}$. at 1911.

45 See Texans for Free Enterprise v. Texas Ethics Comm'n, 732 F.3d 535 (5th 2013); Long Beach Area Chamber of Commerce v. Long Beach, 603 F.3d 684, 696-99 (9th Cir.), cert. denied, 131 S. Ct. 392 (2010)); Wisconsin Right to Life State Political Action Committee v. Barland, 664 F.3d 139, 155 (7th Cir. 2011); New York Progress \& Protection PAC v. Walsh, 733 F.3d 483 (2d Cir. 2013) (approving a preliminary injunction but formally reserving judgment on the merits); Republican Party v. King, 741 F.3d 1089 (10th Cir. 2013).

${ }^{46}$ See N.C. Right to Life, Inc. v. Leake, 525 F.3d 274, 308 (4th Cir. 2008). See also EMILY's List v. FEC, 581 F.3d 1, 4-5 (D.C. Cir. 2009); Richard Briffault, Super PACs, 96 MinN L. REV. 1629, 1642-50 (2012).

${ }^{47}$ See Keating v. FEC, 131 S. Ct. 553 (2010) (denying a writ of certiorari to review SpeechNow.org v. FEC, 599 F.3d 686 (D.C. Cir. 2010)).

48 See FEC Adv. Op. 2010-09 (Club for Growth); FED Adv. Op. 2010-11 (Commonsense 10). 
For 38 years, however, the Supreme Court has distinguished contributions to groups making electoral expenditures from the expenditures made by these groups. It has said that statutory limits on expenditures are subject to "strict" scrutiny. They must not only "further a compelling interest" but also be "narrowly tailored to achieve that interest." 49 The Court has treated limits on contributions to candidates and political groups differently. These limits must merely be "closely drawn" to match a "sufficiently important interest." 50 In its opening paragraph, its closing paragraph, and many places in between, the opinion in Citizens United described the issue before the Court as one of the validity of expenditure limits. The Court noted that "contribution limits, . . . unlike limits on independent expenditures, have been an accepted means of preventing quid pro quo corruption.”51

Contributions to super PACs are in fact contributions. As the Court acknowledged, the validity of limiting contributions of any sort was not before it.

The claim that Citizens United resolved an issue the Court said it was not resolving rests on a single sentence: "[W]e now conclude that independent expenditures .. . do not give rise to corruption or the appearance of corruption."52 SpeechNow reasoned that if independent expenditures do not corrupt, the contributions that make these expenditures possible cannot corrupt either.

As this Article will show, the sentence upon which the D.C. Circuit relied was dictum. Moreover, if read literally, this sentence would be incompatible with the precedents on which the Court purported to rely, with a very recent decision the Court certainly did not mean to disturb (Caperton v. A. T. Massey Coal Co. ${ }^{53}$ ), and with a later statement by the plurality in McCutcheon.

What the Court apparently meant, and indeed the only thing it properly could have decided, was that independent expenditures are insufficiently corrupting to warrant any limitation. Under the Court's twotiered standard of review, an interest can be strong enough to justify a limitation of contributions even when it is insufficient to justify a restriction of expenditures. Reading the crucial sentence to mean only what the Citizens United Court probably did mean would have left the

49 See, e.g., Citizens United, 558 U.S. at 340 (quoting FEC v. Wisconsin Right to Life, 551 U.S. 449, 464 (2007) (opinion of Roberts, C.J.)).

${ }^{50}$ See, e.g., Buckley, 434 U.S. at 30; Nixon v. Shrink Mo. Gov’t Pac, 528 U.S. 377, 387-88 (2000); FEC v. Beaumont, 539 U.S. 146, 158-59 (2003).

51 Citizens United, 558 U.S. at 359; see id. at 356 (again stressing Buckley's distinction between expenditures and contributions).

${ }^{52}$ Citizens United, 558 U.S. at 360.

53556 U.S. 868 (2009). 
validity of Congress's limitation of super PAC contributions unresolved.

In resolving this issue, the D.C. Circuit should have treated as central a question it ignored entirely - whether limits on contributions to super PACs can sensibly be treated differently from the limits on contributions to official campaigns that Buckley v. Valeo upheld. The answer to that question would have been an obvious no. Although Citizens United not only left Buckley undisturbed but relied on it heavily, the D.C. Circuit did not consider the bearing of Buckley on the issue before it.

This Article will examine Citizens United's distinction between preventing quid pro quo corruption (an interest the Court has held can justify Congressional restrictions of speech) and limiting ingratiation and access (an interest that Citizens United says cannot justify any restriction of speech). It will consider four sorts of behavior the proponents of campaign finance regulation might call corrupt-the explicit exchange of favorable governmental action for campaign contributions, the implicit understanding that favorable action will follow contributions, the conscious taking of favorable action in response to contributions without any prior agreement or understanding, and affording gratitude and access to contributors without consciously favoring them in making more substantial decisions. It will conclude that, despite some signals the other way, the Court probably meant to distinguish only between the third and fourth categories. It did not mean to deny that deliberately using public dollars to repay private favors is corrupt and that Congress may prohibit contributions large enough to make conscious favoritism of this sort likely. Under this standard, large super PAC contributions qualify as corrupting.

This Article also will emphasize a related governmental interest that neither Citizens United nor SpeechNow mentioned at all-the anticircumvention interest that became the primary focus of the principal opinions in McCutcheon. The most obvious objection to unlimited super PAC contributions is that they provide a way around statutory limits on contributions to candidates. As the Supreme Court's focus on expenditures in Citizens United slipped into the D.C. Circuit's focus on contributions in SpeechNow, however, neither court addressed this issue. Citizens United should not be read as resolving an issue the Court did not consider.

This Article will propose a legislative scheme for restricting electoral contributions and expenditures grounded on the anti-circumvention principle. This scheme would impose no limits on independent expenditures by either individuals or groups. Subject to some exemptions, however, every group making electoral expenditures would be required to provide an accounting of which individuals had provided 
the funds it spent and how the funds each individual supplied had been allocated to the support of particular candidacies. Individuals and groups would be responsible for ensuring that no more of any individual's funds were used to influence a single election than the law allowed. Groups that for practical reasons could not make the required accounting could establish separate political action committees to receive, spend, and account for individual contributions. This Article will maintain that a legislative scheme of this sort would meet the requirements of Buckley, Citizens United, McCutcheon, and the First Amendment.

This Article also will propose a framework for analyzing campaign finance restrictions that differs from the one the Supreme Court has employed. The Court has treated electoral contributions and expenditures simply as speech and has considered whether the interest in preventing quid pro quo corruption can justify restricting this speech. Contributions and expenditures would better be viewed as hybrids of protected speech and unprotected conduct. These contributions and expenditures affect two different audiences in two different ways. From the perspective of one audience - the public_-political contributions and expenditures look like speech. Their goal is to persuade members of this audience to vote a certain way. From the perspective of a second audience, however-the favored candidate-these contributions and expenditures look like other corrupting gifts. Campaign dollars can persuade a candidate to favor a contributor in the same way that an expense-paid trip to the Super Bowl might persuade him.

The Court's leading decision on hybrids of protected speech and unprotected conduct is United States v. O'Brien, ${ }^{54}$ which upheld convictions of war protestors for destroying their draft cards. Although Buckley v. Valeo concluded that the standard articulated in O'Brien did not apply to campaign finance regulation, it did not consider the sort of argument offered in this Article. Whether one uses the Supreme Court's current mode of analyzing campaign finance issues or the one proposed by this Article, however, SpeechNow was wrongly decided.

Some observers may believe that the train has left the station and that to argue against the SpeechNow ruling is to stand on the station's deserted platform and whistle. They have no doubt that the Supreme Court would approve SpeechNow, and they would not be surprised if the Court were to strike down all limits on campaign contributions too.

I have five comments:

First, Citizens United and McCutcheon were decided by five-to-four votes with the same five justices in the majority in both cases. If even one

54391 U.S. 367 (1968). 
of these justices were to vote to uphold limits on contributions to super PACs, these limits would be likely to stand.

Second, only a Court that wished to preserve a façade of campaign finance regulation while gutting its core would be likely to strike down limits on super PAC contributions while upholding limits on contributions to candidates. A split judgment of this sort could happen, but I am reluctant to attribute disingenuous posturing to any of the justices. The limits on super PAC contributions and the limits on contributions to candidates seem likely to stand or fall together, as they should.

Third, if Justices Kennedy, Scalia, and Thomas were to confront the issue afresh, they apparently would hold all limits on campaign contributions unconstitutional. The other two members of the majority, however, Chief Justice Roberts and Justice Alito, have not indicated that they share this position. In the arguments and opinions in McCutcheon and Citizens United, these justices seemed genuinely concerned about the overbreadth of the challenged statutes. As the McCutcheon plurality argued, forbidding an individual who has contributed the maximum amount to each of nine candidates from contributing to a tenth is a peculiar way of keeping him from contributing too much to any one candidate. ${ }^{55}$ Moreover, as this Article will explain, Citizens United was correct to strike down a statute that blocked a group from preparing and disseminating campaign material simply because this group had organized as a corporation.

Fourth, even justices who would strike down all limits on campaign contributions if they were to consider the issue afresh might hesitate to overrule a line of Supreme Court decisions upholding these limits over the course of almost four decades. ${ }^{56}$

Fifth and finally, the Supreme Court's decision in Citizens United sparked widespread indignation. One week after the decision, President Obama denounced it in his State of the Union address. ${ }^{57}$ Obama's opponent in the presidential election of 2008, Senator McCain, called it "the worst decision ever." 58 Fourteen resolutions in Congress proposed

55 See McCutcheon, 133 S. Ct. at 1448-49.

${ }^{56}$ Cf. Planned Parenthood v. Casey, 505 U.S. 833, 853 (1992) (emphasizing "the force of stare decisis” when reaffirming Roe v. Wade, 410 U.S 113 (1973), 19 years after that decision). In a concurring opinion in Citizens United joined by Justice Alito, Chief Justice Roberts offered an exceptionally thoughtful analysis of the principle of stare decisis. See Citizens United, 558 U.S. at 372 (Roberts, C.J., concurring).

${ }^{57}$ See Adam Liptak, A Rare Rebuke, In Front of a Nation, N.Y. TIMES, Jan. 29, 2010, at A12.

${ }^{58}$ See Alice Robb, McCain Addresses Oxford, OxOniAn GlOBALIST, Oct. 11, 2012, http://toglobalist.org/2012/10/mccain-addresses-oxford/. 
correcting it by constitutional amendment. ${ }^{59}$ A public opinion poll reported $80 \%$ opposition. ${ }^{60}$ A decision striking down all remaining limits on electoral contributions could provoke similar outrage-especially if this decision were by a five-to-four vote and especially if every justice appointed by a Republican president were on one side and every justice appointed by a Democratic president on the other. A constitutional amendment repudiating the Court's position might follow. ${ }^{61}$ The damage that decimating the last remnants of federal election law would do to the Court's reputation could give some justices pause.

\section{AN OVERVIEW OF THIS ARTICLE}

This Article proceeds as follows: Part III, the Part following this one, describes the Citizens United and SpeechNow rulings and how they changed federal election law. It explains why the Supreme Court's statement that independent expenditures do not corrupt was dictum and perhaps double dictum.

Part IV examines how Citizens United and SpeechNow changed the financing of election campaigns. Contrary to widespread perception,

${ }^{59}$ See League of Women Voters, Review of Constitutional Amendments Proposed in Response to Citizens United, http://www.lwv.org/content/review-constitutionalamendments-proposed-response-citizens-united.

60 Dan Eggen, Poll: Large Majority Opposes Supreme Court's Decision on Campaign Financing, WASH. POST, Feb. 17, 2010, http://www.washingtonpost.com/wpdyn/content/article/2010/02/17/AR2010021701151.html.

In political terms, it seemed that five Supreme Court justices had pushed elected officials from the path of an onrushing bus and stood in the path themselves. Citizens United enabled legislators to divert attention from the porousness of their own limitations on political contributions and expenditures and to cast themselves as reformers committed to revoking the license the Supreme Court had issued to buy and sell influence. A five-to-four ruling in which every justice in the majority had been appointed by Republican Presidents and three of the four dissenters had been appointed by Democrats made the Court seem responsible for what some have called a system of legalized bribery.

One suspects that Chief Justice Roberts' decisive vote to uphold most of the Affordable Health Care Act in National Fed'n of Indep. Bus. v. Sibelius, 132 S. Ct. 2566 (2012), was influenced partly by his desire to avoid another five-to-four, Republican vs. Democrat decision invalidating major legislation-a decision that would have made a seemingly partisan Court responsible for America's inability to repair its defective health-care system as well as its defective campaign-finance system. The indignation engendered by Citizens United may not prompt the Supreme Court to reconsider that decision anytime soon, but it might have saved Obamacare.

${ }^{61}$ In retirement, Justice Stevens has joined the call for such an amendment. See John Paul Stevens, Six Amendments: How and Why We Should Change the CONSTITUTION 79 (2014). 
these decisions appear to have produced no significant increase in political spending by large business corporations. Instead they have led to an explosion of large individual contributions.

Part V takes as its text a bumper sticker displayed by opponents of Citizens United: "MONEY IS NOT SPEECH! Corporations are not People!” Both of this bumper sticker's assertions may appear to be nonstarters. Although money is not speech, the First Amendment protects the expenditures needed to bring speech to audiences; and although corporate entities are not people, government may not deny the use of a common and beneficial form of organization to speakers alone.

The bumper sticker nevertheless suggests appropriate concerns. Campaign contributions are not simply funds used to bring speech to audiences; they are also cash gifts likely to influence recipients and beneficiaries in ways the First Amendment does not protect. And although people have a right to use the corporate form of organization when they speak, they have no right to use this form to evade appropriate restrictions of individual speech, including limits on campaign contributions.

Part VI draws on the analysis of Part V and argues that campaign contributions and expenditures should be viewed as hybrids of protected speech and unprotected gifts. When the harms produced by speech do not depend on the message this speech conveys, an all-but insurmountable presumption against legislative regulation is inappropriate.

Part VII proposes a legislative scheme for enforcing statutory limits on individual contributions - one in which, with some exceptions, every organization making electoral expenditures would be required to account for which individuals had supplied the funds it used to influence particular elections.

Citizens United declared that campaign contributions and expenditures may be limited only to prevent quid pro quo corruption. Part VIII considers several possible meanings of the term quid pro quo corruption and which of them the Supreme Court had in mind.

Part IX explains why SpeechNow erred by striking down the BCRA's limits on contributions to super PACs. Not only was the statement in the Citizens United opinion on which D.C. Circuit relied dictum but the Supreme Court gave several indications that it did not mean this statement quite the way it sounds. The central question in SpeechNow should have been whether contributions to super PACs differ significantly from the limits on contributions to official election campaigns that the Supreme Court has upheld, and the answer to this question would have been obvious.

Part X considers whether the ability of a candidate's supporters to 
establish multiple super PACs makes limiting contributions to an individual PAC pointless. It argues among other things that the Supreme Court's decision in McCutcheon does not preclude aggregate limits on super PAC contributions.

Part XI ends the article on a somewhat fanciful note. It explores the implications of SpeechNow by discussing a hypothetical case in which a lobbyist places a newspaper advertisement for a used car dealership owned by a powerful state legislator and also hires a political satirist to deliver a monologue at the legislator's birthday party.

Several appendices follow the Article. They address issues tangential to the Article, and they document at greater length than a footnote could some observations the Article offers along the way.

Appendix A- "Have Citizens United and SpeechNow Ended the Game?"-considers whether, by halting the enforcement of BCRA restrictions, Citizens United and SpeechNow have left no one with standing to raise the issues presented by these cases again.

Appendix B- "The Effect of Campaign Dollars I: Statistical and Non-Statistical Evidence"-examines the efforts of social science researchers to determine whether campaign contributions have influenced the decisions of elected officials.

Appendix C_- “The Effect of Campaign Dollars II: The Generosity of Sheldon Adelson"-considers what motivates one of the largest political donors of all time and what effect his contributions might have had.

Appendix D-“The Effect of Campaign Dollars III: Executive Clemency"-focuses on one kind of official decision that unmistakably has been influenced by campaign contributions.

Appendix E—_"The Effect of Campaign Dollars IV: The Appointment of Ambassadors"-focuses on another.

Appendix F-“Partisan Advantage and Incumbent Protection"considers how much the self-interest of legislators is likely to shape campaign-finance legislation and how ready courts should be to strike down legislation that may have been prompted in part by the legislators' own interests.

\section{Citizens United, SPEechNow, And How These Decisions Changed ELECTION LAW}

For more than 100 years prior to Citizens United, federal law had prohibited corporations from contributing to the campaigns of candidates for federal office, ${ }^{62}$ and labor unions had been subject to the same

62 See 34 Stat. 864, 864-65 (1907) (the Tillman Act). President Roosevelt had urged Congress to enact this prohibition, saying, "Let individuals contribute as they desire; but 
prohibition for 67 years. ${ }^{63}$ Unions and corporations also had been prohibited for 64 years from using funds from their general treasuries to advocate expressly the election or defeat of particular candidates. ${ }^{64}$ These entities, however, could support candidates in several other ways.

First, corporations and unions could use their general funds to establish and pay the administrative expenses of political action committees (PACs), and they could direct these PACs' actions. The PACs could collect contributions in limited amounts from individuals associated with their creators. They could make contributions in limited amounts to candidates for federal office and could make unlimited expenditures of their own to advocate the election of favored candidates. ${ }^{65}$

Second, without using PACs, corporations and unions could place advertisements concerning political issues, and these advertisements could imply support for or opposition to particular candidates. ${ }^{66}$

Finally, unions and corporations could support candidates in communications circulated only within these organizations, and they could engage in "nonpartisan activity designed to encourage individuals to register and vote." 67 "Nonpartisan" get-out-the-vote efforts typically focused on voters likely to support favored candidates. ${ }^{68}$

In Citizens United, a nonprofit corporation sought to make available on cable TV a documentary it had produced disparaging Hillary Clinton, who was then a candidate for the Democratic presidential nomination. Funding and promoting the broadcast might have violated two provisions of the BCRA-one prohibiting the use of corporate funds to advocate expressly the election or defeat of a candidate for federal office ${ }^{69}$ and another prohibiting the use of corporate funds in the period just before an election to produce any "broadcast, cable, or satellite communication"

let us prohibit in effective fashion all corporations from making contributions for any political purpose, directly or indirectly.” 5 THEOdORE ROOSEVELT, Presidential ADDRESSES AND STATE PAPERS 898-99 (1910).

${ }^{63}$ See 57 Stat. 163, 167-68 (1943) (the Smith-Connally Act § 9); 61 Stat. 136, 15960 (1947) (the Taft-Hartley Act § 313).

${ }^{64}$ See 61 Stat. 136, 159 (1947) (the Taft-Hartley Act § 304). See also 2 U.S.C. § $441 \mathrm{~b}(\mathrm{a})$ (codifying the prohibition of corporate and labor union contributions and expenditures).

${ }^{65}$ See 2 U.S.C. $\S 441 \mathrm{~b}(\mathrm{~b})(2)(\mathrm{C})$; Federal ELECTION COMMISSION, SSFS AND NONCONNECTED PACS (2008), available at http://www.fec.gov/pages/brochures/ssfvnonconnected.shtml.

${ }^{66}$ See 2 U.S.C. $\S \S 441 \mathrm{~b}(\mathrm{~b})(2)$ \& 434(f)(3)(A).

${ }^{67}$ See 2 U.S.C. $\S 431(9)(B)($ ii).

68 See Richard Briffault, Corporations, Corruption, and Complexity: Campaign Finance After Citizens United, 20 CORNELL J. L. \& PUBL. POL’y 643, 646-50 (2011).

${ }^{69}$ See 2 U.S.C. $\S 441 b$. 
that even "refer[red] to a clearly identified candidate for federal office."70 The Supreme Court had held that the First Amendment allowed application of the second provision only to communications were the "functional equivalent" of express advocacy. ${ }^{71}$

Citizens United was argued twice. Three months after the initial argument, the Supreme Court restored the case to the docket and ordered the parties to address a question they had not addressed previouslywhether Austin v. Michigan Chamber of Commerce ${ }^{72}$ and a portion of McConnell v. Federal Election Comm' $n^{73}$ should be overruled. ${ }^{74}$ As the first paragraph of Citizens United explained, "Austin . . . held that political speech may be banned based on the speaker's corporate identity," 75 and a portion of McConnell had reiterated that holding. ${ }^{76}$

${ }^{70}$ See 2 U.S.C. $\S \S 441 \mathrm{~b}(\mathrm{~b})(2)$ (prohibiting “electioneering communications”) \& 434(f)(3)(A) (defining “electioneering communications”).

${ }^{71}$ FEC v. Wisconsin Right to Life, 551 U.S 449 (2007).

72494 U.S. 652 (1990).

73540 U.S. 93 (2003).

${ }^{74}$ Order of June 29, 2009, Citizens United v. FEC, 558 U.S. 310 (2010) (No. 08205), http://www.supremecourt.gov/Search.aspx?FileName=/docketfiles/08-205.htm.

${ }^{75}$ Citizens United, 558 U.S at 318.

${ }^{76}$ Jeffrey Toobin offers a fascinating but somewhat baffling account of the deliberations that followed the initial argument in Citizens United. See Jeffrey Toobin, Money Unlimited: How Chief Justice Roberts Orchestrated the Citizens United Decision, THE NEW YORKER, May 21, 2012, http://www.newyorker.com/reporting/2012/05/21/120521fa_fact_toobin?currentPage=al 1 .

Citizens United's counsel, Theodore Olson, maintained that the statutory restrictions did not apply to the group's proposed distribution of its film, and Toobin reports that a majority of the Supreme Court voted at conference to accept Olson's argument. Chief Justice Roberts assigned the majority opinion to himself.

According to Toobin, Justice Kennedy then prepared

a concurrence which said the Court should have gone much further. Kennedy's opinion said the court should declare [the statutory] restrictions unconstitutional, overturn an earlier Supreme Court decision from 1990 [Austin], and gut long-standing prohibitions on corporate giving. But after the Roberts and Kennedy drafts circulated, the conservative Justices began rallying to Kennedy's more expansive resolution of the case. In light of this, Roberts withdrew his own opinion and let Kennedy write for the majority....

The new majority opinion transformed Citizens United into a vehicle for rewriting decades of constitutional law in a case where the lawyer had not even raised those issues. Roberts's approach to Citizens United conflicted with the position he had taken earlier in the term. At the argument of a death-penalty case known as Cone v. Bell, [556 U.S. 499 (2009),] Roberts had berated at length the defendant's lawyer, Thomas Goldstein, for his 
temerity in raising an issue that had not been addressed in the petition. Now Roberts was doing nearly the same thing ....

[Justice] Souter wrote a dissent that aired some of the Court's dirty laundry. . . . [He] accused the Chief Justice of violating the Court's own procedures to engineer the result he wanted.

Id. The Court then ordered reargument, affording the government an opportunity to persuade it not to do what it would have done without hearing argument if Justice Souter had not threatened to make a stink.

What's baffling about Toobin's report is its failure to explain how every member of a majority that initially voted to accept Olson's statutory argument ultimately came to join the Citizens United dissenters in rejecting this argument. Justice Kennedy's majority opinion began by rejecting all of Olson's statutory claims. It concluded that the case could not "be resolved on other, narrower grounds" than those the Court ultimately approved. See Citizens United, 558 U.S. at 322-29.

Unless one of the dissenters in Citizens United initially voted to accept Olson's statutory claims, Justice Kennedy must have been a part of the majority that Toobin says voted to accept these claims. Did Justice Kennedy vote at conference to accept Olson's statutory argument and then think better of it? Or might Toobin's sources (an untrustworthy law clerk or two?) have erred in reporting that a majority of the Court voted to reverse on statutory grounds?

How were Chief Justice Roberts and the other justices who initially voted to accept Olson's statutory claims persuaded to join an opinion rejecting them? At some point, the five justices who agreed that Citizens United should win its case apparently differed among themselves. Some of them apparently favored ruling for Citizens United on statutory grounds while others rejected these grounds but concluded that the group should prevail on the basis of a constitutional argument it had not made. If the case had remained in this posture, Citizens United would have secured a reversal of the lower court's judgment despite the fact that a majority of the Court had expressly rejected its statutory claims and only a minority had concluded that it should win on the basis of a constitutional claim. Two unsuccessful arguments (one of which Citizens United had never offered) would have made the group a winner.

With the Court divided into three minorities (one for reversing on statutory grounds, one for reversing on constitutional grounds, and one for affirming), its decision would have stood for nothing. The Court, however, could not have resolved the difficulty by dismissing certiorari as improvidently granted, for Citizens United had come to the Court on appeal, not certiorari. Summarily affirming a case on appeal leaves the lower court opinion in place (although the Supreme Court does not approve this opinion). Summarily reversing without an opinion or with an opinion noting a hopeless division leaves the case in a lawless limbo.

Might the Chief Justice and others have changed their minds about the merits of Olson's statutory argument simply to avoid an awkward situation? Were these justices willing to reverse their position on a legal question (a not very important legal question) just to move things along? Or did the force of Justice Kennedy's analysis persuade them in a way the government's argument had not and lead them to repudiate an argument they earlier had approved?

The choice for the majority was not simply between a narrower and a broader ground of decision. It was between a narrower ground and an incompatible broader ground. All members of the Court agreed they could not properly address the broader 
Following re-argument, Citizens United did overrule Austin and McConnell. The Court's holding (at least its principal holding) was that "the Government cannot restrict political speech based on the speaker's corporate identity."77 The Court declared that the First Amendment prohibits "restrictions distinguishing among different speakers, allowing speech by some but not by others." 78 It found "no basis for the proposition that, in the context of political speech, the Government may impose restrictions on certain disfavored speakers."79 "Speech restrictions on the identity of the speaker are all too often simply a means to control content," 80 the Court commented. Congress might have prohibited corporate speech simply because it disliked what many corporations have to say. The judgment that Congress may not forbid corporations from speaking or from making political expenditures fully resolved the case before the Court-yet the Court did not stop.

Citizens United mentioned the two branches of the "strict" scrutiny standard Buckley v. Valeo had applied to expenditure restrictionsrequiring both a "compelling interest" and "narrow tailoring" 81 _but the Court's analysis did not clearly separate these branches. Its principal holding apparently concerned "tailoring" or the means Congress had chosen to achieve its goals. However important Congress's objectives might have been, it could not achieve them by prohibiting speech by corporations alone. Once the Court had explained this holding, ${ }^{82}$ it had little reason to discuss the strength of the government's regulatory interests, but it discussed them anyway. ${ }^{83}$

The Court noted that Buckley v. Valeo had regarded only one interest as "sufficiently important" to justify a restriction of campaign contributions - "the prevention of corruption and the appearance of corruption." ${ }^{84}$ Austin had said that Congress also could prevent "immense aggregations of [corporate] wealth” from distorting election results, ${ }^{85}$ but Citizens United returned to Buckley's position. It noted, "When Buckley identified a sufficiently important governmental interest in preventing

ground if the narrower ground sufficed, as some or all members of the majority once might have voted to say that it did.

${ }^{77}$ Id. at 346. See id. at 347 ("[T] he First Amendment does not allow political speech restrictions based on the speaker's corporate identity.”).

${ }^{78} \mathrm{Id}$. at 340.

${ }^{79}$ Id. at 341.

${ }^{80}$ Id. at 340.

${ }^{81} \mathrm{Id}$.

${ }^{82}$ See id. at 336-49.

${ }^{83}$ See id. at 349-62.

${ }^{84}$ Citizens United, 558 U.S. at 345 (quoting Buckley, 424 U.S. at 25).

${ }^{85}$ See Austin, 494 U.S. at 684. 
corruption or the appearance of corruption, that interest was limited to quid pro quo corruption." 86 The Court said that "[t]he practices Buckley noted would be covered by bribery laws if a quid pro quo arrangement were proved." 87 It added, "Ingratiation and access are not corruption." 88 After offering its narrow view of corruption, the Court concluded, "The anticorruption interest is not sufficient to displace the speech here in question." ${ }^{89}$ This statement fully resolved the case before the Court a second time.

The familiar principle that a court should not decide constitutional issues in advance of necessity ${ }^{90}$ means among other things that it should not make two constitutional decisions when one will do. As Chief Justice Roberts observed before becoming Chief Justice, "[I]f it is not necessary to decide more, it is necessary not to decide more." ${ }^{91}$ Either branch of the Citizens United opinion, however, would have sufficed without the other. Once the Court had said that the government may not restrict independent expenditures on the basis of corporate identity, there was no reason for it to consider in addition whether the government may not restrict these expenditures at all. And if the Court had said initially that independent expenditures are insufficiently corrupting for Congress ever to restrict them, there would have been no reason for it to consider in addition whether this speech-related activity may be restricted on the basis of corporate identity.

Even after resolving the case before it twice, the Court did not stop. Three sentences after it declared that " $[t]$ he anticorruption interest is not sufficient to displace the speech here in question," it went farther: "[W]e now conclude that independent expenditures, including those made by corporations, do not give rise to corruption or the appearance of corruption." 92 The Court's first formulation declared the anticorruption interest insufficient to support any restriction of political expenditures. The second declared this interest nonexistent. A declaration that independent expenditures do not corrupt at all went far, far, far beyond the necessities of the case.

The Court slipped easily from one formulation to the other, but the difference between them is great. If the Court had merely declared the anticorruption interest insufficient, Citizens United would have said

${ }^{86} \mathrm{Id}$. at 359.

${ }^{87}$ Id. at 908 (citation to 18 U.S.C. $\S 201$, a federal bribery statute, omitted).

${ }^{88} I d$. at 360.

${ }^{89}$ Citizens United, 558 U.S. at 357.

${ }^{90}$ See, e.g., Ashwander v. TVA, 297 U.S. 288, 346-47 (1936).

${ }^{91}$ PDK Labs, Inc. v. United States DEA, 362 F.3d 786, 799 (D.C. Cir. 2004)

(Roberts, J., concurring in part).

${ }^{92}$ Citizens United, 558 U.S. at 357. 
nothing about the validity of Congress's limitation of contributions to super PACs. Under the Court's two-tiered standard of review, an interest can be strong enough to justify a limitation of contributions even when it is not strong enough to justify a limitation of expenditures.

Since Buckley in 1976, the Court has struck down every expenditure limitation to come before it, but it has upheld most contribution limitations. ${ }^{93}$ If, in Citizens United, Court had decided the case before it only twice and then stopped, one might have anticipated a repetition of the pattern: Although Congress could not limit super PAC expenditures, it could limit contributions to these groups. A nonexistent interest, however, cannot justify anything. The Court's declaration that the government had no regulatory interest whatever was dictum or perhaps double dictum (a statement unnecessary to a discussion that itself was unnecessary). ${ }^{94}$

The Court's off-hand transition from labeling the government's regulatory interest inadequate to labeling it nonexistent suggests that it might not have been attuned to the important difference between these formulations that Buckley's two-tiered standard of review created. This Article will note other indications that the Court did not mean its broader

93 The Court struck down expenditure limits in Buckley v. Valeo, 424 U.S. 1 (1976); First National Bank of Boston v. Bellotti, 435 U.S. 765 (1978); FEC v. Nat'l Conservative Pol. Action Comm., 470 U.S. 480 (1985); FEC v. Massachusetts Citizens for Life, 479 U.S. 238 (1986); Colorado Republican Campaign Comm. v. FEC, 518 U.S. 604 (1996) (Colorado I); and Citizens United v. FEC, 558 U.S. 310 (2010). It upheld contribution limits in Buckley v. Valeo, 424 U.S. 47 (1976); California Medical Ass'n v. FEC, 453 U.S. 182 (1981); Nixon v. Shrink Missouri Government PAC, 528 U.S. 377 (2000); and FEC v. Beaumont, 539 U.S. 146 (2003). The Court struck down contribution limits in Citizens Against Rent Control v. Berkeley, 454 U.S. 290 (1982) (declaring limits on contributions to groups supporting or opposing referendums unconstitutional because these contributions pose no risk of corrupting public officials) and Randall v. Sorrell, 548 U.S. 230 (2006) (invalidating Vermont's extremely low limits).

In FEC v. Colorado Republican Fed. Campaign Comm., 533 U.S. 431 (2001) (Colorado II), the Court held that when a group's expenditures are not "independent" of a campaign, they must be treated as contributions to the campaign. It said, "[W]e have routinely struck down limitations on independent expenditures by candidates, other individuals, and groups while repeatedly upholding contribution limits.” Id. at 441-42 (emphasis and citations omitted).

94

See

OXFORD

DICTIONARIES,

http://www.oxforddictionaries.com/us/definition/american_english/obiter-dictum

(defining obiter dictum as “a judge's incidental expression of opinion, not essential to the decision and not establishing precedent”). The dissenters in McCutcheon declared that Citizens United's "statements . . . about the proper contours of the corruption rationale" should be regarded "as dictum, as . . . overstatement, or as limited to the context in which [they] appear." McCutcheon, 134 S. Ct. at 1471 (Breyer, J., dissenting). 
declaration quite the way it sounds. ${ }^{95}$

Other broad formulations offered by the Citizens United opinion, moreover, have not fared well. Although the Court announced that the First Amendment prohibits "restrictions distinguishing among different speakers, allowing speech by some but not by others," 96 the majority opinion itself revealed that this declaration was not as unqualified as it seemed. The Court acknowledged that it had upheld limits on speech simply because the speaker was a student, a prisoner, a civil servant, or a member of the military. It explained that "these rulings were based on an interest in allowing governmental entities to perform their functions."97 What the Court meant, apparently, was that limitations of speech may not distinguish among speakers unless these limitations enable the government to perform some function. ${ }^{98}$

Two years after Citizens United, however, the Court abandoned even this narrower proposition. It summarily upheld a ban on campaign contributions by non-citizens who were not permanent residents of the United States. ${ }^{99}$ The declaration that the government may not restrict speech on the basis of a speaker's identity evidently had become inoperative. $^{100}$

The Supreme Court did not disavow its statement that "the Government cannot restrict political speech based on the speaker's corporate identity"101_the statement that had appeared to be Citizens United's principal holding. The federal courts of appeals, however, have not taken this statement seriously. The only four to rule on the question have held that total bans on corporate contributions to election campaigns survive Citizens United, and the Supreme Court denied certiorari in two of these cases. ${ }^{102}$

${ }^{95}$ See text at notes infra.

${ }^{96}$ Citizens United, 558 U.S. at 340.

${ }^{97} \mathrm{Id}$. at 341.

98 The Court seemed to conclude that the government may distinguish among speakers only when it occupies a special supervisory role over those it restricts.

${ }^{99}$ See Bluman v. FEC, 132 S. Ct. 1087 (2012) (summarily affirming Bluman v. FEC, 800 F. Supp. 281 (D.D.C. 2011)).

100 See William SAFire, SAfire's Political Dictionary 346 (rev. ed. 1993) (defining "inoperative" as "a correction without an apology, leaving the corrector in a deep hole").

Citizens United itself had said, "We need not reach the question whether the Government has a compelling interest in preventing foreign individuals or associations from influencing our Nation's political process.” 558 U.S. at 362. Even leaving this question open indicated that, despite the Court's broad language, it was not committed to the proposition that all distinctions among speakers are invalid.

${ }^{101}$ Id. at 346 (emphasis added).

${ }^{102}$ See Minnesota Citizens Concerned for Life v. Swanson, 692 F.3d 864, 877-80 
Seven years before Citizens United, the Supreme Court had upheld Congress's prohibition of corporate contributions to candidates, ${ }^{103}$ and the majority opinion in Citizens United did not expressly overrule this decision. The courts of appeals relied in part on the Court's declarations that when one of its precedents applies directly, lower courts "should ... leav[e] to this Court the prerogative of offering its own decisions." 104 These courts also insisted, however, that Citizens United had no application to contribution limits. The Second Circuit declared, for example, "In Citizens United, the Supreme Court held that the government cannot prohibit independent expenditures in support of a political candidate based on the source's corporate identity. Contrary to Appellant's exhortation, however, Citizens United applies only to independent corporate expenditures.... It therefore has no impact on the issues before us in this case.” 105

The courts of appeals and the Supreme Court itself have deflated Citizens United's declarations that legislatures may not restrict speech on the basis of the speaker's identity. They have done so despite the fact that the Court's declaration that government may not limit the speech on the basis of corporate identity appeared to be its principal holding. Although Citizens United's declaration that independent expenditures do not corrupt was dictum and although the Court offered several indications that it did not mean this statement to be as sweeping as it seemed, the courts of appeals have not deflated it. ${ }^{106}$ To the contrary, following the

(8th Cir. 2012) (en banc); United States v. Danielczyk, 683 F.3d 611, 617 (4th Cir. 2012), cert. denied, 133 S. Ct. 1459 (2013); Ognibene v. Parkes, 671 F.3d 174, 183-84 (2d Cir.), cert. denied. 133 S. Ct. 28 (2012); Thalheimer v. City of San Diego, 645 F.3d 1109, 1124-27 (9th Cir. 2011); Green Party of Conn. v. Garfield, 616 F.3d 189, 199 (2d Cir. 2010).

${ }^{103}$ FEC v. Beaumont, 539 U.S. 146 (2003).

${ }^{104}$ E.g., Agostini v. Felton, 521 U.S. 203, 237 (1997).

${ }^{105}$ Ognibene, 671 F.3d at 183.

106 Describing a Supreme Court holding narrowly and refusing to consider its implications for other situations is bad judging. The courts of appeals, however, could have made this move to deflate the Supreme Court's statement that independent expenditures do not corrupt at least as easily as they could have to deflate its statements that government may not restrict speech on the basis of corporate identity. In fact, the declaration that independent expenditures do not corrupt formally addressed only expenditures while the declarations that government may not restrict speech on the basis of corporate identity apparently referred to both expenditures and contributions. By insisting that Citizens United concerned only expenditures, the courts of appeals disregarded more than the implications of its declarations that government may not restrict speech on the basis of corporate identity; they disregarded what these declarations said. Taking the Court's language seriously, however, would have produced very unfortunate consequences that the Court probably did not intend. See text at notes infra. 
lead of the D.C. Circuit, they have read it for all it might be worth.

The D.C. Circuit maintained in SpeechNow that, if expenditures by super PACs do not corrupt, contributions to these groups cannot corrupt either. These contributions can influence public officials only through the expenditures that the Supreme Court has declared non-corrupting as a matter of law. ${ }^{107}$ Although contribution limits are judged by a less demanding standard than expenditure limits, the D.C. Circuit said that the standard of review did not matter. "“[S]omething ... outweighs nothing every time." "'108 Acknowledging even a smidgen, soupçon, or scintilla of regulatory interest would have undercut the court's analysis entirely.

\section{How CITIZENS UNITED AND SPEECHNOW CHANGED ELECTION FINANCING}

On the day the Supreme Court decided Citizens United, President Obama described it as "a major victory for big oil, Wall Street banks, health insurance companies and . . other powerful interests." 109 Critics of the decision spoke of "corporate dominance of politics." 110 The practical significance of the Court's judgment that large business organizations may make independent expenditures on behalf of candidates for office, however, has been close to nonexistent. The creation of super PACs and the authorization of limitless contributions to these groups, however, transformed American politics.

Citizens United and SpeechNow were followed by a stunning increase in outside spending in federal election campaigns. ${ }^{111}$ The first postCitizens United congressional elections came in 2010, ten months after the Supreme Court's ruling. In the campaign leading up to the preceding non-presidential federal election in 2006, outside spending totaled \$69

107 SpeechNow, 599 F.3d at 694-95.

${ }^{108}$ Id. at 695 (quoting Nat'l Ass'n of Retired Fed. Employees v. Horner, 879 F.2d 873, 879 (D.C. Cir. 1989), and adding, "All that matters is that the First Amendment cannot be encroached upon for naught”).

109 Press Release, White House Office of the Press Secretary, Statement from the President on Today's Supreme Court Decision (Jan. 21, 2010), available at http://www. whitehouse.gov/the-press-office/statement-president-todays-supreme-courtdecision- 0 .

110 See, e.g., Fran Korten, 10 Ways to Stop Corporate Dominance of Politics: It's Not Too Late to Limit or Reverse the Impact of the Supreme Court's Disastrous Decision in Citizens United v. FEC, YES! MAGAZINE, http://www.yesmagazine.org/people-power/10-ways-to-stop-corporate-dominance-ofpolitics.

${ }^{111}$ By outside spending, I mean spending controlled neither by candidates nor by party committees. 
million. In 2010, it was \$316 million. ${ }^{112}$

The first presidential election following Citizens United and SpeechNow was the election of 2012. During the preceding 2008 campaign, outside groups spent $\$ 338$ million on all federal races. In 2012, they spent $\$ 1$ billion, 38 million. ${ }^{113}$

The 1310 super PACs that participated in the 2012 campaign accounted for more than half of the total outside spending - \$609 million. They collected far more than that in contributions- $\$ 828$ million. ${ }^{114}$

About $70 \%$ of all contributions to super PACs came from individuals rather than collective entities of any sort-corporations, labor unions, nonprofits, and political action committees. ${ }^{115}$ Only about 9\% of the contributions came from corporations. ${ }^{116}$ More than $25 \%$ of the corporate contributions came, not from true business enterprises, but from "shell corporations used by individuals . . . to cloak their donations." 117

In the 2012 election cycle, not a single Fortune 500 company made any independent expenditure to support or oppose a candidate for federal office. Only ten contributed to super PACs. ${ }^{118}$ Of these ten, only one contributed more than \$1 million-Chevron Corporation, which donated $\$ 2.5$ million to a super PAC close to House Speaker John Boehner. ${ }^{119}$ In

112 See OpenSecrets.org, Total Outside Spending by Election Cycle, Excluding Party Committees, http://www.opensecrets.org/outsidespending/cycle_tots.php?cycle=2012\&view=A\&cha $\mathrm{rt}=\mathrm{N} \#$ viewpt.

${ }^{113}$ Id. For an argument that some of the "exponential leap in political spending” that followed Citizens United might have occurred anyway, see Matt Bai, How Much Has Citizens United Changed the Political Game?, N.Y. TIMES, July 17, 2012, at MM 14.

114 See OpenSecrets.org, 2012 Outside Spending, by Super PAC, http://www.opensecrets.org/outsidespending/summ.php?cycle=2012\&chrt=V\&type=S.

115 See Anupama Narayanswamy, Corporate, Union, and Nonprofit Giving to Super PACs Tops $\$ 167$ Million, Sunlight Foundation REPORTING GROUP BlOG, Oct. 22, 2012, http://reporting.sunlightfoundation.com/2012/organizational-giving/.

116 See Adam Bonica, Avenues of Influence: On the Political Expenditures of Corporations and Their Directors and Executives 10 (2013), available at http://ssrn.com/abstract=2313232.

${ }^{117}$ Id. (noting that nearly $\$ 20$ million of the $\$ 75$ million contributed by corporations was attributable to these shells).

118 See Wendy Hansen, Michael S. Rocca, \& Brittany Ortiz, The Effects of Citizens United on Corporate Contributions in the 2012 Presidential Election (2013) (APSA 2013 Annual Meeting Paper), available at http://papers.ssrn.com/sol3/papers.cfm?abstract_id=2300930. Although the cited paper reported that only nine Fortune 500 companies contributed to super PACs, id. at 20, its authors later discovered one additional contributor. Email to the author from Michael S. Rocca, Jan. 17, 2014.

119 See Hansen et al., supra note, at 20; Dan Eggen, Chevron Donates \$2.5 Million

to GOP Super PAC, WASHINGTON POST, Oct. 26, 2012, 
other words, all 500 of the Fortune 500 companies declined the invitation offered by Citizens United to make independent expenditures, and 490 of them declined the invitation offered by SpeechNow to contribute to super PACs. ${ }^{120}$

The misperception that corporations dominate political campaigns stems partly from media descriptions of the amounts contributed by "business interests" and by specified industries like "the energy industry" and "the financial services industry." These statements are likely to convey the impression that the contributions were made by businesses. Almost invariably, however, the statements are traceable to the Center for Responsive Politics, which includes individual contributions in its compilations of interest-group donations. The Center attributes a contribution to a group by noting the occupation and employer listed by the individual contributor. ${ }^{121}$

Excluding individual donations would be misleading; some individual donations are made for the purpose of advancing their donors' business interests. As the following discussion will indicate, however, including these donations may be even more misleading. ${ }^{122}$

http://www.washingtonpost.com/blogs/post-politics/wp/2012/10/26/chevron-donates-25-million-to-gop-super-pac/.

${ }^{120}$ Wendy Hansen and her co-authors comment, “Over 500 of the world's largest and most powerful companies opted to stay away from donating to SuperPACs during an election where SuperPACs spent over $\$ 600$ million . . . ” Hansen et al., supra note , at 21. The authors refer to "over" 500 corporations because they examined the expenditures of 545 companies in order to include all that made the Fortune 500 list in either 2008 or 2012. Id. at 11.

Some of the business corporations that neither made independent expenditures nor contributed to super PACs undoubtedly contributed to 501(c)(4) groups and 501(c)(6) trade associations-particularly the U.S. Chamber of Commerce. In 2012, the Chamber began sponsoring ads expressly urging the election or defeat of particular candidates, and it spent \$35.7 million influencing federal elections. See OpenSecrets.org, US Chamber of Commerce, http://www.opensecrets.org/outsidespending/detail.php?cycle $=2012 \& \mathrm{cmte}=U \mathrm{US}+\mathrm{Cham}$ ber+of+Commerce. Contributions to 501(c)(4) and 501(c)(6) groups, however, are not reported publically. See note supra.

About two-thirds of the Fortune 500 companies have established conventional PACs. The electoral spending of these PACs increased 15\% between 2008 and 2012. This amount was "about half the percentage increase over the same period of major non-corporate PACs.” Id. at 15. Neither Citizens United nor Speech Now affected the ability of conventional PACs to make political donations.

121 See OpenSecrets.org, 2012 Overview: Business-Labor-Ideology Split in PAC \& Individual Donations to Candidates, Parties, Super PACs, and Outside Spending Groups, http://www.opensecrets.org/overview/blio.php. The Center for Responsive Politics is a respected nonpartisan group that, among other things, analyzes campaign finance statistics and makes them readily accessible.

122 The Center itself clearly divides interest group contributions into those made by 
Corporate executives have contributed a remarkable amount to political campaigns - well over $\$ 1$ billion in each of the most recent election cycles. ${ }^{123}$ As Adam Bonica recently discovered, 83\% of all Fortune 500 directors and CEOs have made political contributions at some point in their careers. Moreover, of those who have failed to contribute, many are foreign nationals barred from doing so. ${ }^{124}$ The contribution rate of the nearly 4500 top-firm executives Bonica studied greatly exceeds that of doctors (15 to 20\%) and lawyers (45 to 50\%). ${ }^{125}$ The average amount a contributing executive had given to campaigns over the years was $\$ 197,000$. The median was $\$ 39,000$. These figures do not include the amounts given by spouses. ${ }^{126}$

Despite a common perception of the corporate world as a fortress of conservatism, "the typical board [of a publically traded Fortune 500 company] includes donors from across the ideological spectrum," ${ }^{127}$ and "ideologically homogenous firms are quite rare." 128 The distribution of campaign contributions by Fortune 500 executives skews to the right and to the Republican Party, but only moderately. ${ }^{129}$ This tilt could "as easily be explained as a function of [the] demographics [of a group disproportionately composed of white males over 50] as it could by the supposed link between the corporate interests and Republican policies." 130

The contributions of business executives seem less strategic and more the product of ideology than those of their businesses' PACs. Executives are far less likely than business PACs to contribute to both candidates in a single race. ${ }^{131}$ (Forty-three executives, however-3\% of all contributors - did give to both presidential nominees in 2012, and 114 did so in 2008. ${ }^{132}$ ) Executives are also far less likely to tilt their contributions toward the party in power. ${ }^{133}$ If the contributions of business executives are made to advance "business interests," the donors plainly have differing ideas of how best to advance these interests.

individuals and those made by PACs. See id.

${ }^{123}$ See Bonica, supra note, at 16.

${ }^{124}$ Id. at 15.

${ }^{125} \mathrm{Id}$. at 32-33.

${ }^{126}$ Id. at 15.

${ }^{127} \mathrm{Id}$. at 37.

${ }^{128}$ Id. at 35. An exception is the energy industry, which "stands out for the conservatism of its management and work force." Id.

${ }^{129} I d$. at 28-32.

${ }^{130} \mathrm{Id}$. at 29.

${ }^{131} \mathrm{Id}$. at 18-19.

132 Id. at 19, Table 2.

${ }^{133}$ Id. at 20-23. 
Candidates and office holders may not assign individual contributions to interests in the same way the Center for Responsive Politics does.

When a Fortune 500 company's endorsement of a candidate would alienate many of its directors, executives, and shareholders, the company is unlikely to make an endorsement. The company may have other reasons for declining to contribute to super PACs as well. About half the customers of a business corporation marketing to the public would be likely to support the opponent of whichever candidate the corporation endorsed. Unlike lobbying on an issue affecting the corporation's interests, ${ }^{134}$ participation in a general election campaign is often bad for business. ${ }^{135}$ Entities that do not market to the public (labor unions and trade associations in particular) are more likely to make large contributions. Richard Epstein calls electoral spending a constitutional right that large corporations do not want. ${ }^{136}$

Ninety-five individuals or couples and 56 organizations contributed $\$ 1$ million or more to outside spending groups in 2012. ${ }^{137}$ Together they contributed almost $60 \%$ of the total amount collected by these groups. ${ }^{138}$ At the top of the list were Sheldon and Miriam Adelson, who together

134 See Bonica, supra note, at 2 (“[C]orporate lobbying expenditures have historically eclipsed PAC contributions by ratios of more than ten to one.”).

135 See, e.g., Jia Lynn Yang \& Dan Eggen, Exercising New Ability to Spend on Campaigns, Target Finds Itself a Bull's-Eye, WASH. Post, Aug. 19, 2010, http://www.washingtonpost.com/wpdyn/content/article/2010/08/18/AR2010081806759.html (describing the national boycott that followed Target's contribution to a gubernatorial candidate in Minnesota who opposed same-sex marriage).

136 See Richard A. Epstein, Corporate Speech and Electoral Spending: Citizens United v. FEC: The Constitutional Right that Big Corporations Should Have but do not Want, 34 HARV. J.L. \& PUB. POL'Y 391 (2011). Apart from the fact that a corporation's participation in an election campaign may be bad for business, permitting corporate contributions exposes businesses to implicit extortion-the unspoken threat that rejecting a request for funds may lead to reduced access or less favorable treatment.

137 See OpenSecrets.org, 2012 Top Donors to Outside Spending Groups, http://www.opensecrets.org/outsidespending/summ.php?cycle=2012\&disp=D\&type $=\mathrm{V}$ \&superonly $=\mathrm{N}$. Among the lists that appear at this website are one for top individual contributors in 2012 and another for top organizational contributors. A menu enables a viewer to toggle from one list to the other. The discussion that follows draws from a merger of the two lists.

138 See Keenan Steiner \& Jacob Fenton, The 2012 Super PAC Million Dollar Club, Sunlight FOUNDATION REPORTING GrouP, Dec. 7, 2012, http://reporting.sunlightfoundation.com/2012/2012-super-pac-million-dollar-club/ (using figures slightly different from those reported by the Center for Responsive Politics); Adam Lioz \& Blair Bowie, Billion-Dollar Democracy: The Unprecedented Roll of Money in the 2012 Elections, DEMOS, Jan. 17, 2013, http://www.demos.org/publication/billion-dollar-democracy-unprecedented-rolemoney-2012-elections. 
gave $\$ 92.8$ million. Following them were three more individuals or couples (Harold and Annette Simons, who contributed \$26.9 million; Robert Perry, who gave \$23.5 million; and Fred Eychaner, who gave \$14.1 million). Then came a labor union (the United Auto Workers, \$14 million); an individual (Michael Bloomberg, \$13.7 million); another union (Service Employees International, \$13.3 million); another individual (Joe Ricketts, \$13.1 million); and another union (the National Educational Association, \$13 million).

The top corporate contributor finally appeared at number 10 on the list-Specialty Group Inc., a mysterious enterprise that filed its incorporation papers less than a week before contributing its first \$5 million and that ultimately contributed $\$ 10.6$ million. ${ }^{139}$ One must go past three more individuals and six more unions before encountering a second business corporation-Oxbow Corp., an energy development holding company founded by Bill Koch, a brother of Charles and David Koch, ${ }^{140}$ which contributed $\$ 4.4$ million.

The business corporations that contributed $\$ 1$ million or more (22) slightly outnumbered the unions that did (20), ${ }^{141}$ but the amount contributed by the 20 unions (\$102 million) was more than double that contributed by the 22 corporations (\$50 million). Most of the corporations that gave $\$ 1$ million or more appeared to be closely held by one or a few owners. Several in fact seemed to be straws created for the purpose of masking their owners' contributions. ${ }^{142}$

\footnotetext{
${ }^{139}$ See Jack Gillum, Specialty Group Inc., Mystery Firm, Formed Days Before \$5 Million Campaign Gift, HUFFINGTON Post, Oct. 27, 2012, http://www.huffingtonpost.com/2012/10/27/specialty-group-inc-

donation_n_2031207.html; William Rose, Press Release (Nov. 3, 2012), http://www.documentcloud.org/documents/502074-press-release-from-william-rose-onfreedomeworks.html (statement by Knoxville resident William Rose declaring that he is "the CEO, President and General Counsel of Specialty Group," that the company is developing land his family has owned for 50 years, and that "[o]ver the past several weeks, the failings of the Obama administration . . . have been hidden by the mainstream news media, with Fox News leading the lonely path towards the truth”).
140
See
WIKIPEDIA, Bill
Koch
(Businessman), http://en.wikipedia.org/wiki/Bill_Koch_(businessman) (last visited Aug. 5, 2013).

${ }^{141}$ The organizations contributing $\$ 1$ million or more that were neither labor unions nor business corporations were mostly political groups-for example, the Republican Governors Association and the League of Conservation Voters.

142 See Corporations or People? Let's Ask Romney About Eli Publishing, F8LLC, Spann LLC and Paying Taxes, MN Political RoundTABle, Aug. 13, 2011, http://mnpoliticalroundtable.com/2011/08/13/corporations-or-people-let's-ask-romneyabout-eli-publishing-f8-llc-spann-llc-and-paying-taxes/ (noting, for example, that $\mathrm{W}$ Spann LLC filed incorporation papers in March, contributed \$1 million to Restore Our Future in April, and was dissolved in July). See Michael Beckel \& Reity O’Brien, Mystery Firm is Election's Top Corporate Donor at \$5.3 Million, OpenSecretsblog,
} 
Wendy Hansen, Michael Rocca, and Brittany Ortiz, the authors of a study of political spending by Fortune 500 companies, concluded, "Corporate political spending changed very little following the Citizens United ruling." 143 Adam Bonica's bottom line was similar: "In a careful accounting of corporate political expenditures, I find little evidence that the recent Supreme Court ruling in Citizens United has had any practical effect on how corporations spend on politics."144 But large contributions by individuals have skyrocketed.

\section{REFLECTIONS ON A BUMPER STICKER}

A bumper sticker marketed to people offended by the Citizens United decision proclaims, "MONEY IS NOT SPEECH! Corporations are not People!" ${ }^{45}$ Justice Alito has called it "very frustrating” for a Supreme Court opinion to be "reduced to a slogan that you put on a bumper sticker."146 The bumper sticker, however, provides a place to start. This section assesses some basic campaign finance issues by considering what's wrong and what's right about the sticker's two assertions.

\section{A. "Money is not Speech"}

\section{Why the Bumper Sticker Gets It Wrong (Mostly)}

The declaration that money is not speech appears not only on bumper stickers but also on refrigerator magnets, T-shirts, ${ }^{147}$ and a proposed constitutional amendment endorsed by more than 360,000 petition signers. ${ }^{148}$ The city councils of Los Angeles, California and Portland, Oregon have passed resolutions declaring that money is not speech, and voters in Boulder, Colorado and Madison, Wisconsin have approved referenda saying the same thing. ${ }^{149}$

Nov. 5, 2012, http://www.opensecrets.org/news/2012/11/mystery-firm-is-elections-topcorpo.html.

${ }^{143}$ Hansen et al., supra note , at 18.

${ }^{144}$ Bonica, supra note , at 36.

145 See http://www.cafepress.com/mf/70462926/money-is-not-speech bumpersticker?utm_medium=cpc\&utm_term=758086923\&utm_source=google\&utm_campaig $\underline{\mathrm{n}=\text { sem-cpc-product-ads\&utm_content=search-pla\&productId=758086923. }}$.

${ }^{146}$ See Laurence Tribe and Joshua Matz, UnCertain Justice: The Roberts Court AND the CONSTITUTION 96 (2014) (quoting Alito and citing a Boston.com website story that apparently is no longer on the web).

147 See, e.g., http://www.zazzle.com/money is not speech_bumper_sticker128314648852904232.

${ }^{148}$ See https://movetoamend.org (last visited Aug. 17, 2014).

149 See Geoffrey R. Stone, Is Money Speech?, Huffington Post, Feb. 5, 2012, 
It is true that money is not speech, but the First Amendment could not protect speech unless it also protected other things. As Geoffrey Stone has observed, a bus is not speech, but a law forbidding bus rides to political rallies would violate the First Amendment. ${ }^{150}$ Although money is not speech, Congress could not prohibit the use of money to buy a book. In Buckley v. Valeo, ${ }^{151}$ the Supreme Court rejected the D.C. Circuit's conclusion that contribution and expenditure limitations "should be viewed as regulating conduct not speech." 152 As the Court observed, one cannot send a telegram or publish a newspaper without spending money. ${ }^{153}$ Unless critics of Citizens United would allow Congress to suppress newspapers by prohibiting the expenditures needed to publish them, they cannot resolve the First Amendment issues posed by campaign finance regulations simply by proclaiming that money is not speech.

\section{Why the Bumper Sticker Gets It Right (Partly)}

The Constitution protects the expenditures needed to bring speech to an audience, but that is not the only thing campaign contributions and expenditures do. These contributions and expenditures have harmful effects not produced by the messages they deliver. They differ greatly from the spending necessary to publish a newspaper or send a telegram.

Unlike the funds used to publish a newspaper or send a telegram, political contributions are intended to influence, and do influence, two audiences. From the perspective of one of these audiences-the publicthey look like speech. Their goal is to persuade the audience of some proposition ("vote Obama"). American democracy could not function without them.

From the perspective of a second audience, however-the favored candidate-political contributions look like other corrupting gifts. They do not persuade the candidate to support his own candidacy. Instead, they may persuade him to provide favors to the contributors. When they do,

http://www.huffingtonpost.com/geoffrey-r-stone/is-money-speech_b_1255787.html.

${ }^{150} \mathrm{Id}$.

151424 U.S. 1 (1976).

152 Id. at $15-16$.

${ }^{153} \mathrm{Id}$. at 17 . Western Union sent its last telegram in 2006, thirty years after Buckley. See Dan Tynan, 10 Technologies that Should Be Extinct (But Aren't), PC WoRLD, July 4, 2010, http://www.pcworld.com/article/200325/10_technologies that should be extinct.html. One can still send a telegram through iTelegram, which recommends using the service for, among other things, weddings, special occasions, sympathy, and fun and romance. See http://www.itelegram.com. 
they persuade him in the same way that an expense-paid trip to an old golf course in Scotland might persuade him. ${ }^{154}$ Campaign cash is just as good as money. ${ }^{155}$

The principal reason for restricting the receipt of political contributions does not differ from the reason for restricting the receipt of golf outings, honoraria, tickets to sporting events, Christmas baskets, and private employment. Campaign contributions corrupt as much as these other valued benefits. Because the contributions serve an important public purpose, however, there is greater reason for tolerating the corruption.

The codes of conduct that limit the ability of public officials to accept gifts are described as curbing conflicts of interest. The Supreme Court's campaign finance decisions consume more than 1500 pages of the reports, however, and the words conflict of interest do not appear. The Supreme Court speaks more obscurely of "the actuality and appearance of corruption." 156

Speaking of conflicts of interest would be better. ${ }^{157}$ To be sure, this language would sound less grand. Corruption has an ominous ring, and curbing it sounds like a more "compelling” governmental interest. Speaking of conflicts of interest, however, would underscore the need to draw a line between permissible and impermissible conflicts. The Supreme Court sometimes has seemed hesitant to recognize this necessity.

Attempting to eliminate all conflicts of interest would be a fool's errand. Conflicts are ubiquitous. An effort to stamp all of them out would leave public officials without any social life, family life, religious life, or political life. This effort also would violate the First Amendment. Congress could not prohibit a $\$ 100$ contribution simply because it might make its beneficiary somewhat more receptive to the contributor's entreaties.

Strong conflicts of interest, however, are appropriately forbidden. The interest in preventing them is both important and compelling. ${ }^{158}$ The

154 See Wikipedia, List of Trips Funded by Jack Abramoff, http://en.wikipedia.org/wiki/List_of_trips_funded_by_Jack_Abramoff (last visited Nov. 13, 2013).

155 See Yogi Berra, WIKIQUOTE, http://en.wikiquote.org/wiki/Yogi_Berra (last visited Sept. 25, 2012) (noting Yogi Berra’s statement in an AFLAC commercial, “And they give you cash which is just as good as money”).

156 Buckley, 424 U.S. at 26.

157 Twenty-five years ago, Daniel Lowenstein noted, "[T]he question of campaign finance is a question of conflict of interest.” See Daniel Hays Lowenstein, On Campaign Finance Reform: The Root of All Evil is Deeply Rooted, 18 HOFSTRA L. REV. 301, 324 (1989).

158 When the Constitution is read to safeguard unlimited contributions to super PACs, laboring over a code of government conduct looks like rearranging deck chairs on the Titanic. A code might prohibit a lobbyist from sending a legislator a \$100 
Lincoln bedroom, ${ }^{159}$ the ambassadorship to Luxembourg, ${ }^{160}$ and pardons for the friends and families of major donors ${ }^{161}$ need not remain up for grabs. Small political contributions usually are motivated by a desire to persuade the public rather than buy influence. Large contributions are likely to be motivated by both a desire to persuade the public and the hope of gaining clout. ${ }^{162}$ Forbidding some conflicts of interest is an excellent idea.

In Citizens United, the Supreme Court cited the impossibility of drawing a principled line between large and small conflicts of interest as its reason-its only reason-for excluding from its concept of corruption every conflict of interest except those created by bribes. Justice Kennedy's opinion for the Court quoted an earlier opinion by Justice Kennedy, noting that this earlier opinion was a separate opinion but not that it was a dissent. He wrote, "Favoritism and influence are not . . . avoidable in representative politics. It is the nature of an elected representative to favor certain policies, and, by necessary corollary, to favor the voters and contributors who support those policies.”'163 Moreover, "[a] 'generic favoritism or influence theory is at odds with standard First Amendment analyses because it is unbounded and susceptible to no limiting principle." 164 Justice Kennedy apparently saw

Christmas gift, but the restriction would hardly matter. The lobbyist would have a simpler and easier way to buy influence.

159 During the 2000 presidential campaign, candidate George W. Bush accused President Clinton of "virtually renting out the Lincoln bedroom to big campaign donors." He condemned using this "hallowed chamber" for political purposes. Helen Thomas, Selling Lincoln Bedroom Disrespectful, HEARST NEWSPAPERS, Sept. 28, 2002, http://www.seattlepi.com/news/article/Selling-Lincoln-bedroom-disrespectful-

1097153.php. Later, however, Bush, like his predecessor, hosted many major contributors as overnight guests in the White House. A presidential spokesman refused to say in which bedrooms they slept. Id.

${ }^{160}$ See Appendix E to this Article, "The Appointment of Ambassadors."

${ }^{161}$ See Appendix D to this Article, "Executive Clemency."

${ }^{162}$ Laurence Tribe once posed the following thought experiment to his First Amendment class: Imagine a high-tech information filter that can reveal information to one audience while blocking it from another. Imagine further that the law mandates the use of this device to make the sources of campaign financing transparent to the public but anonymous to the benefitted candidates. Then consider how many contributors would still pour millions of dollars into campaigns. Email to the author from Laurence Tribe, Sept. 29, 2012. For less hypothetical proposals to conceal the identity of donors from candidates, see Bruce AcKerman \& IAN Ayers, Voting With Dollars: A NeW PARADIGM FOR CAMPAign FINANCE 48-50, 102-04 (2004); Ian Ayers \& Jeremy Bulow, The Donation Booth: Mandating Donor Anonymity to Disrupt the Market for Political Influence, 50 STAN. L. REV. 837 (1998).

163 Citizens United, 558 U.S. at 359 (quoting McConnell v. FEC, 540 U.S. 93, 297 (2003) (Kennedy, J., dissenting)).

${ }^{164}$ Id. (again quoting McConnell v. FEC, 540 U.S. 93, 297 (2003) (Kennedy, J., 
no alternative to leaving the ambassadorship to Luxembourg and much more up for grabs.

The Supreme Court, however, often draws "unprincipled" lines of the sort Citizens United declined to draw. In Nixon v. Shrink Mo. Gov't Pac ${ }^{165}$ for example, the Court upheld Missouri's low contribution limits, and then, in Randall v. Sorrell, ${ }^{166}$ it invalidated Vermont's even lower limits. The Court has recognized that legislatures must make judgment calls and that courts charged with safeguarding the First Amendment must review the reasonableness of these calls.

The distinction between the two audiences and the two different ways of persuading them has been lost on some Supreme Court justices. The dissenters in Citizens United cited the scholarship of Zephyr Teachoutscholarship showing that the Framers of the Constitution "were obsessed with corruption,' which they understood to encompass the dependency of public officeholders on private interests." ${ }^{167}$ In a concurring opinion joined by Justices Thomas and Alito, Justice Scalia objected that the Framers' concept of corruption could not justify restricting speech: "[I]f speech can be prohibited because, in the view of Government, it leads to 'moral decay' or does not serve 'public ends,' then there is no limit to the Government's censorship power.” 168

Limiting contributions and expenditures because the political messages they send could persuade viewers, listeners, and readers to

dissenting)).

165528 U.S. 377 (2000).

166548 U.S. 230 (2006).

167 Citizens United, 558 U.S. at 452 (Stevens, J., dissenting) (quoting Zephyr Teachout, The Anti-Corruption Principle, 94 CORNELl L. REV. 341, 348 (2009)).

Teachout's scholarship sometimes produces a surprisingly uncomprehending response. Critics note the ubiquity of the kind of corruption she describes, the impossibility of eliminating this corruption, and the unfairness of calling every official who considers anything but the public good "corrupt."

Teachout, however, did not suggest that the Constitution allows Congress to prohibit all speech that creates conflicts of interest and that diverts officials from serving the public. She did not set forth a standard for separating protected from unprotected speech. She simply emphasized an interest to be weighed against the expressive value of speech and showed how important this interest was to the Framers of the Constitution. Moreover, Teachout would not call officials who fail to focus entirely on the public good dishonest; her point was that the word "corruption" sometimes refers, not to dishonesty, but to falling away from an Aristotelian ideal of public service. Corruption in the sense most often invoked by the Framers is a matter of more or less, not yes or no.

Teachout argued that the interest in minimizing conflicts of interest is sometimes strong enough to justify limiting speech. For an examination of where the contrary view would lead, see text at notes infra.

${ }^{168}$ Id. at 391 (Scalia, J., concurring). 
favor selfish interests or might cause moral decay of the part of these audiences certainly would offend the First Amendment. No one, however, has proposed limiting contributions and expenditures because the messages they send corrupt their audiences. Providing valued gifts to governmental officials to encourage them to disregard the public interest is entitled to no First Amendment protection.

The plurality in McCutcheon also seemed oblivious to the difference between campaign contributions and speech that sends a message to only one audience. It wrote, "Money in politics may at times seem repugnant to some, but so too does much of what the First Amendment vigorously protects. If the First Amendment protects flag burning, funeral protests, and Nazi parades - despite the profound offense such spectacles causeit surely protects political campaign speech despite popular opposition." 169

The public, however, does not seek to suppress campaign contributions for the same reason legislators once sought to suppress flag burning and Nazi marches. Its quarrel is not with the content of the advertisements broadcast by Democrats and Republicans. What makes money in politics repugnant to many is the ability of backers of both Republicans and Democrats to secure official favors. The messages Republican and Democratic donors send the public differ from one another, but the conflicts of interest created by their contributions look a lot alike. The McCutcheon majority seemed slow to recognize the difference between limiting conflicts of interest and censoring repugnant speech. It was too quick to claim the mantle of Milton, Mill, Holmes, and Brandeis.

The defenders of Citizens United and the critics of this decision sometimes have seemed like the blind men describing the elephant. ${ }^{170}$ The defenders have failed to acknowledge the extent to which political contributions and expenditures differ from other funds used to bring speech to audiences. The critics, however, have seen these contributions as corrupting without acknowledging the crucial role they play in enabling speech. Both sides have been wrong and both right. ${ }^{171}$

169 McCutcheon, 134 S. Ct. at 1441.

170 This Article is headed toward a record in the use of hackneyed metaphors. Readers are requested to envision an elephant in a stateroom on the Titanic unmentioned except by a group of blind passengers who describe it to an orphaned murderer in a deck chair after the ship has left the station.

171 Some critics' concern about conflicting interests is mixed with concern about buying elections and distorting election results-a concern that does raise questions about censorship. 


\section{B. "Corporations are not People"}

\section{Why the Bumper Sticker Gets It Wrong (Mostly)}

Some of the constitutional amendments proposed to "overrule" Citizens United insist, "[H]uman beings, not corporations, are persons entitled to constitutional rights." ${ }^{172}$ Justice Stevens wrote for the dissenters in Citizens United, "[The Framers] had little trouble distinguishing corporations from human beings, and when they constitutionalized the right to free speech in the First Amendment, it was the free speech of individual Americans that they had in mind." 173 Delegates to the 2012 Democratic Convention cheered Elizabeth Warren when she told them, "Corporations are not people. People have hearts, they have kids, they get jobs, they get sick, they cry, the dance. They live, they love, and they die. And that matters. That matters because we don't run this country for corporations, we run it for people." ${ }^{174}$

Even the motorists whose bumper stickers decry Citizens United, however, might not deny corporations all constitutional rights. One doubts, for example, that they would convict these entities of crimes without affording them the right to counsel and the right to jury trial. ${ }^{175}$ At the same time, no one has proposed affording corporations the right to vote. It apparently is necessary to distinguish some constitutional rights from others, something that cannot be done on a bumper sticker.

In 2012, Mitt Romney responded to an audience member's repeated shouts of the word corporations by saying, "Corporations are people, my friend." ${ }^{176}$ This answer prompted widespread ridicule. The Chairperson

\footnotetext{
172 See the website https://movetoamend.org (favoring a constitutional amendment with the language quoted in text); Tester's Constitutional Amendment, Scribd., http://www.scribd.com/doc/148533402/Tester-s-Constitutional-Amendment (presenting the text of a constitutional amendment sponsored by Senators Jon Tester and Chris Murphy: "We the people who ordain and establish this Constitution intend the rights protected by this constitution to be the rights of natural persons.").

${ }^{173}$ Citizens United, 558 U.S. 310, 428 (Stevens, J., dissenting).

${ }^{174}$ See Elizabeth Warren Addresses DNC: “The System is Rigged,” REAL ClEAR PolitiCs, Sept. 5, 2012, http://www.realclearpolitics.com/video/2012/09/05/elizabeth_warren_addresses_dnc_th e_system_is_rigged.html.

175 Affording these rights to corporations seems uncontroversial. Nevertheless, "[f]or ever-shifting reasons, all of them bad, the Supreme Court has held the privilege against self-incrimination inapplicable to corporations.” Albert W. Alschuler, Two Ways to Think About the Punishment of Corporations, 46 AM. CRIM. L. REV. 1359, 1366 (2009).

${ }^{176}$ See Philip Rucker, Mitt Romney Says “Corporations are People” at Iowa State Fair, WASH. POST, Aug. 11, 2011, available at http://articles.washingtonpost.com/2011-
} 
of the Democratic National Committee called it a "shocking admission," 177 and a poster portrayed Romney as declaring, "Of course corporations are people. Some of my best friends are corporations!”

People probably would not have seen Romney as ridiculous, however, if he had said, "Baseball teams are people, my friend," "church congregations are people," or "labor unions are people." Indeed, if Romney had seemed ridiculous after making one of these other comments, it might have been because he saw the need to verbalize something so obvious.

Why might listeners have accepted descriptions of labor unions as people while rejecting similar descriptions of corporations? Was it just that some people consider corporations more beastly? Or does the statement that "unions are people" sound like an obvious truth-simply a recognition that members comprise these organizations-while the statement that "corporations are people" sounds like an obvious falsehood-a preposterous statement about corporate entities themselves? One guesses that Romney meant only to remind his audience of the human beings who consider themselves part of corporate organizations and without whom these organizations would not exist, but listeners heard him deny that a fictional entity was fictional. ${ }^{178}$

The Citizens United majority and its critics appeared to make the same error. Both took a legal fiction seriously and envisioned a corporation owned by many people simply as a single entity. The majority insisted that this entity should be treated no differently from an individual speaker while critics saw it as a nonhuman thing without rights. Analogizing a corporation to a single person or a single thing, however, is usually a mistake. ${ }^{179}$ What might be called the Romney move-piercing the corporate veil and focusing on the human beings behind it—sharpens the issues. ${ }^{180}$

08-11/politics/35270239_1_romney-supporters-mitt-romney-private-sector-experience.

${ }^{177} \mathrm{Id}$.

178 Romney had no hope of correcting the misunderstanding. Although Justice Brandeis famously declared that the remedy for falsehood and fallacies is "more speech,” Whitney v. California, 247 U.S. 357, 377 (Brandeis, J., concurring), he never ran for office.

179 See Alschuler, supra note (arguing that blaming corporations for the crimes committed by their employees is comparable to blaming animals and inanimate objects and commenting, "The embarrassment of corporate criminal liability is that it punishes the innocent along with the guilty,” id. at 1637).

180 In Burwell v. Hobby Lobby Stores, 134 S. Ct. 2751, 2768 (2014), the Court belatedly explained, "When rights, constitutional or statutory, are extended to corporations, the purpose is to protect the rights of [the people (including shareholders, officers and employees) who are associated with the corporation in one way or another].” One wishes the Citizens United majority had made the same statement and 
Agreeing that only human beings have First Amendment rights begs the question what rights they have. Does the Constitution guarantee them not only the right to speak as individuals but also the right to join with others for the purpose of speaking? And if the First Amendment entitles them to form "speech groups," why should the groups they form be denied the benefits of corporate organization? Should only non-speaking business entities be allowed to incorporate? Should these nonhuman (or, if you prefer, subhuman) organizations have special privileges denied to groups that speak?

Just as the government may not prohibit using a bus to ride to a political rally, it should not be allowed to prohibit the use of a common and beneficial form of organization simply because organizers wish to engage in protected speech. A widely available organizational tool cannot constitutionally be denied to speakers alone. Like a bus, incorporation can help speakers get where they're going. It would be more precise to say that people have a right to use the corporate form when they speak than to say that corporations have a right to speak, but it is difficult to see an important difference between the two formulations. ${ }^{181}$

Citizens United was not the first Supreme Court decision to recognize the right of speakers to employ the corporate form of organization. The Court cited no fewer than 25 earlier decisions in which it had recognized the First Amendment rights of incorporated groups. ${ }^{182}$

In fact, the Supreme Court had decided a case very much like Citizens United 24 years earlier. In FEC v. Massachusetts Citizens for Life, ${ }^{183}$ a nonprofit corporation sought to distribute broadly a newsletter headlined "EVERYTHING YOU NEED TO KNOW TO VOTE PROLIFE." 184 The Court recognized the group's right to distribute this newsletter. It held Congress's prohibition of corporate expenditures "in connection with" federal election campaigns unconstitutional as applied to nonprofit corporations formed for the sole purpose of expressing political ideas. The Court's opinion was by Justice Brennan.

Citizens United differed from Massachusetts Citizens for Life in only one respect. The plaintiff in Citizens United, unlike the plaintiff in Massachusetts Citizens for Life, accepted donations from for-profit corporations. The Supreme Court, however, has recognized the First-

considered its implications.

${ }^{181}$ Because the right ultimately belongs to individuals, the government should be allowed to take reasonable steps to ensure that they wish to exercise this right-in other words, to ensure that the people on the bus want to go where it's going.

182 See Citizens United, 558 U.S. at 342.

183479 U.S. 238 (1986).

184 See id. at 243. 
Amendment rights of for-profit corporations too. As Michael McConnell observed, “The vast majority of the Court's press cases involve for-profit corporations . . ., and no one, even in dissent, has ever suggested that corporate status mattered in those cases.”185

The Sierra Club is a nonprofit corporation, and the New York Times is a for-profit corporation. Unless the critics of Citizens United would deny the right to speak and publish to the Sierra Club and the Times, they cannot plausibly maintain that only "human beings, not corporations, are persons entitled to constitutional rights."

Citizens United held Congress's prohibition of independent electoral expenditures by unions and corporations unconstitutional 64 years after its enactment. One year after its enactment, however, Justices Rutledge, Black, Douglas, and Murphy declared in a concurring opinion that they would hold this prohibition unconstitutional. ${ }^{186}$ They did so in a case in which the majority found it unnecessary to reach the question but did say that it would have "the gravest doubt" about the prohibition's constitutionality if it were construed to prevent internal distribution of a list of union endorsements. ${ }^{187}$ Nine years later, in another case in which the majority found it unnecessary to resolve the question, Chief Justice Warren joined a dissenting opinion in which Justices Douglas and Black reiterated their view that the prohibition was unconstitutional. ${ }^{188}$

At the time Chief Justice Warren and Justices Rutledge, Black, Douglas, and Murphy declared that they would hold Congress's prohibition of independent expenditures by unions and corporations unconstitutional, Congress had enacted only token restrictions on contributions by individuals. ${ }^{189}$ When people were effectively free to give as much as they liked to whichever candidates they liked, there was no substantial reason to limit their ability to join others in making and coordinating contributions and expenditures - and no substantial reason to deny the groups they formed the benefits of corporate organization.

Once Congress had limited individual contributions, however, and once the Supreme Court had recognized Congress's power to do so, the appropriate analysis changed. The government then had a strong interest

185 See McConnell, supra note , at 417.

186 United States v. CIO, 335 U.S. 106, 143 (1948) (Rutledge, J., concurring in the result).

${ }^{187}$ Id. at 121 (majority opinion).

188 United States v. Automobile Workers, 352 U.S. 567, 593 (1957) (Douglas, J., joined by Warren, C.J., and Black, J., dissenting).

189 The Hatch Act amendments of 1940 limited individual contributions to a federal candidate or political committee to $\$ 5000$ per year but did not prevent a donor from giving that amount to multiple committees working for the same candidate and coordinating their electoral efforts. See Ch. 640, 54 Stat. 767 (1940). 
in preventing the use of organizations to circumvent individual contribution limits. Neither the majority nor the dissenters in Citizens United seemed to notice the change.

2. Why the Bumper Sticker Gets It Right (Partly)

\section{a. Contributions}

One morning, Mr. Hyde donated the maximum allowable amount to Senator Claghorn's reelection campaign. ${ }^{190} \mathrm{He}$ said to the senator, "Of course there's no quid pro quo, but I hope you'll support subsidies for the widget industry, which would create thousands of jobs."

Mr. Hyde later donned dark glasses, a fedora, and a false mustache. That afternoon, he again contributed the maximum amount to Senator Claghorn's campaign. "I am not Mr. Hyde," he told the senator in a falsetto voice. "I am the Jeckyll Corporation, a leading manufacturer of widgets. Like my friend Hyde, however, I hope you'll support enormous subsidies for our industry."

The case of Mr. Hyde and the Jeckyll Corporation prompts the following observations.

\section{i. Corporate Entities Are Not People}

As noted above, every federal court of appeals to address the issue has held that Congress's prohibition of corporate contributions to election campaigns survives Citizens United. ${ }^{191}$ If the courts had taken more seriously the Supreme Court's declaration that "the Government cannot restrict political speech based on the speaker's corporate identity,"192 however, they would have afforded corporations the same right as individuals to make political contributions. Every corporation then could have donated $\$ 2600$ per candidate per election. ${ }^{193}$

The number of corporations an individual can form is unlimited. If, after donating \$2600 to Senator Claghorn himself, Mr. Hyde had created 100 corporations, each of these corporations could have contributed $\$ 2600$ to the senator's campaign. By making contributions through these

190 Senator Beauregard Claghorn, an invention of radio comedian Fred Allen, is remembered today, not for his legislative accomplishments, which were nonexistent, but for his devotion to the South-devotion so deep that he refused to wear a union suit or drive through the Lincoln Tunnel. See WIKIPEDIA, Senator Claghorn, http://en.wikipedia.org/wiki/Senator_Claghorn (last visited Nov. 22, 2013).

191 See text at note supra.

192 Citizens United, 558 U.S. at 346.

193 See 2 U.S.C. § 441a(a)(1); 78 Fed. Reg. 8532 (2013). 
corporations, Mr. Hyde would have gained more clout than he should have-101 times more. At the same time, Koch Industries, with 60,000 employees and annual revenues of $\$ 115$ billion, ${ }^{194}$ could have contributed a total of $\$ 2600$. The fearsome corporate mountain could have given birth to a mouse. As the bumper sticker insists, analogizing corporate entities to individual speakers is misguided. The number of artificial legal entities people create should not affect what they can give.

The people who own corporations are not artificial entities. In Elizabeth Warren's words, they live, love, and die. The reason some corporate contributions are appropriately forbidden is not that corporations are sub-human, demonic entities entitled to no constitutional rights. Rather, the reason is the opposite: "Corporations are people, my friend." The people who comprise a corporation are entitled to only their fair share of clout. Their contributions to particular candidates should be subject to effective limitation.

\section{ii. Limiting and Equalizing Clout}

This Article has maintained that campaign contributions are hybrids of protected speech and unprotected, influence-generating gifts to candidates. The limits on contributions upheld by Buckley $v$. Valeo mark the point at which the danger of conflicting interests appears to outweigh the benefits of electoral speech.

When people aggregate small contributions, however, they can create large conflicts of interest. One thousand members of the National Widget Association, for example, might each contribute the maximum amount to Senator Claghorn's campaign, and each might accompany his contribution with a note thanking the senator for his unwavering support of the right to bear widgets. Senator Claghorn later might vote against a proposed widget-control measure, not because he or most of his constituents disapproved of the measure, but because he hoped to keep the Widget Association members' cash flowing. The persuasion worked by these members' contributions would not have been the kind the First Amendment protects, but no constitutional regime of campaign finance regulation could have blocked it.

This Article will endorse a scheme of campaign finance regulation in which organizations may bundle contributions and act as the contributors' spending agents. A bundling group—call it a political action committee - could collect a large enough war chest that candidates might be wary of offending it.

194 See Forbes, America's Largest Companies, http://www.forbes.com/largestprivate-companies/list/, last visited June 22, 2014. 
The situation obviously differs when Mr. Hyde, wearing 1000 disguises, has contributed 1000 times more than the law allows. Although the aggregate amount of improper influence he purchased might have been no different from that purchased by 1000 lawful contributions, Mr. Hyde would have gained an unfair advantage. He is entitled to no more than his fair share of clout. Even when limits on individual contributions do not block the creation of conflicts of interest, they limit people to their proportionate share of clout.

The Supreme Court has rejected a different equalization claim-that the government may prevent the political contributions of the wealthy from "distorting” election results. Although Austin embraced a variation of this claim, ${ }^{195}$ Buckley, Citizens United, and McCutcheon firmly repudiated it. In each of these cases, the Supreme Court observed that restricting the speech of some in order to equalize the speech of others is "wholly foreign to the First Amendment."196

The government could not block a wealthy person from writing and distributing a pamphlet on a political issue (or from publishing this pamphlet as a full-page advertisement in the New York Times) simply because opponents of his position were less wealthy and less able to disseminate their views. Equalizing electoral speech seems similarly objectionable.

Equalizing clout differs, however, from equalizing speech and is not "foreign to the First Amendment." Although the First Amendment guarantees a marketplace of ideas, ${ }^{197}$ it does not guarantee a marketplace in clout. The argument for equalizing clout does not focus at all on the advantage that wealth may provide in conveying messages to the public or on distorted election results. It focuses on a kind of influence the First Amendment does not protect.

\section{iii. Anonymous Clout}

In McCutcheon, the Supreme Court maintained that even if funds donated to a group unassociated with a candidate might find their way into this candidate's coffers, "it is hard to see how a candidate today could receive a 'massive amount[] of money' that could be traced back to

195 See Austin, 494 U.S. at 684 (declaring that Congress may prevent "immense aggregations of [corporate] wealth" from distorting election results).

${ }^{196}$ See Buckley, 424 U.S. at 25; Citizens United, 558 U.S. at 349-50; McCutcheon, 134 S. Ct. at 1450.

197 See Abrams v. United States, 259 U.S. 616, 630-31 (Holmes, J., dissenting) ("[T]he best test of truth is the power of the thought to get itself accepted in the competition of the market.”). 
a particular contributor." 198 It observed that when "the chain of attribution grows longer, ... any credit must be shared among the various actors along the way." 199 It spoke of the hurdles election law poses "for a donor who seeks both to channel a large amount of money to a particular candidate and to ensure that he gets the credit for doing so."200 The Court apparently assumed that a donor could have illegitimate influence only when the recipient knew his identity.

When Mr. Hyde, disguised as the Jeckyll Corporation, contributed a second time to Senator Glaghorn's campaign, however, the influence he gained did not depend on Senator Claghorn's ability to see through his disguise (that is, to pierce his corporate veil). In both of Mr. Hyde's personae, he made Senator Claghorn aware of the amount of his contribution and what he wanted. When the amount contributed is large enough, these two conditions can create campaign-cash clout. Mr. Hyde believed that his two contributions together would reinforce the senator's appreciation of the central role of widgets in our economy-and not because they would persuade the senator of anything. Clout need not be personal clout; someone who remains anonymous but contributes to an influence-buying fund has clout too. To block improper influence, one must obscure both the identity and the objectives of a donor. ${ }^{201}$

\section{b. Expenditures}

All corporations-not just shell corporations, one-person corporations, and closely held corporations-offer paths around contribution limits. Moreover, corporate expenditures may provide a broader circumvention path than corporate contributions.

Although no Fortune 500 company has yet accepted Citizens United's invitation to make an independent expenditure to advocate a candidate's election, ${ }^{202}$ suppose that one does. The massive Jeckyll Corporation spends \$1 million to create and broadcast an advertisement urging Senator Claghorn's reelection.

Suppose that, prior to this expenditure, Mr. Hyde, the owner of 5\% of the outstanding shares of Jeckyll Corporation, had contributed as much as the law allowed to Senator Claghorn's campaign. The corporation's independent expenditure on behalf of Senator Claghorn was not Mr. Hyde's independent expenditure.

\footnotetext{
${ }^{198}$ McCutcheon, 134 S. Ct. at 1452-53.

199 Id. at 1452.

${ }^{200}$ Id. at 1446.

${ }^{201}$ See note supra.

${ }^{202}$ See text at notes supra.
} 
When the Supreme Court first distinguished between contributions and expenditures, it explained, "The transformation of contributions into political debate involves speech by someone other than the contributor."203 When one person funds another's speech, the First Amendment protects his contribution less than the speech he finances. The distinction between contributions and expenditures apparently proceeds from the same intuition that prompted the bumper sticker's declaration that money is not speech: Writing checks is something less than speaking. ${ }^{204}$

Although political contributors usually write checks, Mr. Hyde did less. Funds that he and others owned were already in the Jeckyll Corporation treasury for managers to use to promote the reelection of Senator Claghorn if they liked. Five percent of the corporation's \$1 million expenditure $(\$ 50,000)$ was attributable to Mr. Hyde's share of these funds. This cash bought Mr. Hyde more than his fair share of clout. $^{205}$

One can appropriately presume an identity of interest between corporate managers and shareholders. (If one couldn't, protecting shareholders from the use of their funds to support candidates they oppose would supply a strong reason for forbidding political spending by corporations. ${ }^{206}$ ) The candidates backed by a corporation are likely to be the same candidates its shareholders support through their own contributions. Many shareholders are likely to give enough as individuals that allowing them to provide additional support through their corporations would send their contributions beyond the limit.

This Article will propose a mechanism for allowing political

${ }^{203} \mathrm{Id}$

204 The Court's distinction expresses this intuition in a considerably milder form than the bumper sticker. It treats the money a speaker uses to bring speech to an audience (the speaker's own expenditures) like speech itself, and it treats writing a check to the speaker, not as non-speech, but as low-value speech. The Court nevertheless agrees with its bumper-sticker critics that the First Amendment does not protect check writing as much as it protects full-fledged speech.

${ }^{205}$ For one thing, Mr. Hyde had more clout than his equally wealthy twin sister, a strong proponent of widget control. Mr. Hyde's sister had invested her wealth, not in a business corporation, but in art and precious metals. The law blocked her from contributing more than other individuals could contribute.

206 See FEC v. National Right to Work Comm., 459 U.S. 197, 208 (1982) (recognizing the government's interest in protecting “individuals who have paid money into a corporation or union for purposes other than the support of candidates from having that money used to support political candidates to whom they may be opposed"); FEC v. Beaumont, 539 U.S. 146, 155 (2003) (same); but see Citizens United, 558 U.S. at 362 (observing that the procedures of corporate democracy allow shareholders to protect their interests). 
contributions and expenditures through corporations, unions, and other groups while ensuring individual compliance with contribution caps. If neither this mechanism nor an alternative seems workable, however, the bumper sticker's bottom line begins to look good: corporate contributions and expenditures should be forbidden. If the answer must be either yes or no, it should be no.

The reason the bumper sticker gets it partly right is again the opposite of the reason it gives. No objection in principle to corporate electoral expenditures is persuasive. People should be allowed to contribute as much through unions and corporations as they can as individuals. But they should not be allowed to contribute more. Contributions and expenditures by corporations allow their shareholders to give when everyone else has been required to stop. Piercing the veil exposes the double counting. Mr. Hyde and the Jeckyll Corporation turn out to be the same person. ${ }^{207}$

Neither the majority nor the dissenters in Citizens United mentioned the government interest in preventing the circumvention of individual contribution limits. The government's briefs never asked the Court to consider this interest. Seven years before Citizens United, however, in FEC v. Beaumont, ${ }^{208}$ the Supreme Court relied in part on the anticircumvention interest when it upheld Congress's prohibition of corporate campaign contributions. Although the Court spoke only of contributions and not expenditures, its analysis had implications for both:

Quite apart from war-chest corruption and the interests of contributors and owners, ... . another reason for regulating corporate electoral involvement has emerged with restrictions on individual contributions, and recent cases have recognized that restricting contributions by various organizations hedges against their use as conduits for "circumvention of [valid] contribution limits." To the degree that a corporation could contribute to political candidates, the individuals "who created it, who own it, or whom it employs," could exceed the bounds on their own contributions by diverting money through the corporation . .$^{209}$

${ }^{207}$ Cf. L. FranK BAuM, THE WONDERFul WiZARD OF Oz 183 (1900) ("[T]hey saw, in just the spot the screen had hidden, a little old man, with a bald head and a wrinkled face, who seemed to be as much surprised as they were.”)

208539 U.S. 146 (2003).

${ }^{209} \mathrm{Id}$. at 155 (internal citations omitted). 
Citizens United should not be read as rejecting Beaumont's analysis or as resolving an issue the Supreme Court did not consider.

b. Other Regulations

Just as corporate contributions and expenditures provide a way around contribution limits, they provide a way around other regulations - in particular, the BCRA's disclosure requirements ${ }^{210}$ and its prohibition of contributions by foreign nationals. ${ }^{211}$

Wealthy individuals responded to SpeechNow by forming shell corporations whose only purpose was to make multi-million dollar contributions to super PACs-contributions whose human sources these donors wished to conceal. ${ }^{212}$ And although federal law bars Kim Jong-un, the Supreme Leader of North Korea, from contributing to Senator Claghorn's reelection campaign, nothing blocks his investment in a corporation likely to use its funds to support the senator. ${ }^{213}$ If, like $\mathrm{Mr}$. Hyde, the Supreme Leader owned 5\% of the publically traded Jeckyll Corporation, he would effectively have contributed $\$ 50,000$ to Senator Claghorn's campaign. ${ }^{214}$

The critics of Citizens United and the defenders of this decision again resemble the blind men describing the elephant. The critics fail to see the legitimate interests of the human beings behind the corporate veil while

210 See, e.g., 2 U.S.C. § 434(b)(3).

211 See 2 U.S.C. § 441e.

212 See text at notes supra. See generally Richard Briffault, Nonprofits and Disclosure in the Wake of Citizens United, 10 ELECTION L.J. 337 (2011).

${ }^{213}$ Kim Jong-un may not himself participate in the "decision making process" that produces a corporation’s political expenditures. See 11 C.F.R. 110.20(i).

214 Although Citizens United did not discuss using corporations to circumvent the BCRA's base limits, it did note the possibility of circumventing the BCRA's prohibition of contributions by foreign nationals:

We need not reach the question whether the Government has a compelling interest in preventing foreign individuals or associations from influencing our Nation's political process. Section $441 \mathrm{~b}$ is not limited to corporations or associations that were created in foreign countries or funded predominantly by foreign shareholders. Section 441b therefore would be overbroad even if we assumed, arguendo, that the Government has a compelling interest in limiting foreign influence over our political process.

Citizens United, 558 U.S. at 362. The Court did not explain its apparent assumption that only corporations created in foreign countries or funded predominantly by foreign shareholders pose a risk of circumvention. If the Court would uphold $\S 441 \mathrm{~b}$ 's application to corporations funded in part by foreign shareholders, few if any publically traded corporations could make electoral expenditures. 
the defenders fail to see the ways in which the people behind this veil can use the corporate form to evade appropriate regulation. Once more both sides have been wrong and both right.

\section{A FRAMEWORK FOR ANALYZING THE CONSTITUTIONALITY OF CAMPAIGN FINANCE REGULATION}

\section{A. John Hart Ely's Variation on a Theme by O'Brien}

This Article has maintained that campaign contributions and expenditures combine valued speech and corrupting gifts in a single package. The Supreme Court's leading decision on hybrids of protected speech and unprotected conduct is United States v. O'Brien, ${ }^{215}$ in which the Court upheld the convictions of war protestors for destroying their draft cards. It said:

[W]hen "speech" and "nonspeech" elements are combined in the same course of conduct, a sufficiently important governmental interest in regulating the nonspeech elements can justify incidental limitations on First Amendment freedoms. . . . [A] government regulation is sufficiently justified if it is within the constitutional power of Government; if it furthers an important or substantial governmental interest; if the government interest is unrelated to the suppression of free expression; and if the incidental restriction on alleged First Amendment freedoms is no greater than is essential to the furtherance of that interest. ${ }^{216}$

As John Hart Ely observed, the distinction between speech and conduct does not fully capture what made O'Brien distinct from most other First Amendment cases. ${ }^{217}$ Arguments for limiting speech usually focus on the message a speaker delivers. They maintain that this message deceives, defames, persuades listeners to harm others, prompts violent retaliation, offends unwilling audiences, injures some audiences (particularly children), and/or generates long-range cultural harm.

215391 U.S. 367 (1968).

${ }^{216}$ Id. at 376-77.

217 See John Hart Ely, Flag Desecration: A Case Study in the Roles of Categorization and Balancing in First Amendment Analysis, 88 HARV. L. REV. 1482, 1491-1502 (1975). See also LAURENCE H. TRiBe, AMERICAN CONSTITUTIONAL LAW 829-30 (2d ed. 1988); Laurence H. Tribe, Toward a Metatheory of Free Speech, 10 Sw. U.L. REV. 237, 242 (1978). 
The First Amendment creates strong barriers to limiting speech because its message offends or injures. When the harm produced by speech does not proceed from its message, however, Ely maintained that a strong presumption against regulation is inappropriate. The important distinction is not between speech and conduct but between harms produced by a speaker's message and harms that do not proceed from this message. The Supreme Court came closer to the mark when it spoke of a "government interest unrelated to the suppression of free expression"218 than when it spoke of conduct that combines "speech" and "nonspeech" elements. ${ }^{219}$ The corrupting influence of campaign funds on a candidate does not depend on the message these funds send the public. ${ }^{220}$

\section{B. Can Campaign Speeches be Hybrids Too?}

As this article has noted, conflicts of interest are ubiquitous. Conflicts can arise from any favor, including one that takes the form of verbal speech. A president's campaign appearances with a candidate, for example, might create a stronger sense of indebtedness than a $\$ 50,000$ contribution to the candidate's campaign. An influential labor leader might endorse a candidate partly to curry the candidate's favor.

Although speeches endorsing a candidate can combine protected speech with unprotected clout buying, endorsement speeches merit categorical protection. ${ }^{221}$ These speeches differ from campaign contributions and expenditures in several ways, and when balancing could not justify restriction, there is no reason to do it.

${ }^{218}$ O’Brien, 391 U.S. at 377.

219 Id. at 376.

${ }^{220}$ Of course campaign contributions would have no value to a candidate if the messages they sent could not persuade a larger audience. That proposition would be true even of contributions given in return for explicit promises of favorable government action-contributions that could lead to 15-year sentences for bribery. See McCormick v. United States, 500 U.S. 257 (1991); 18 U.S.C. § 201. Hardly anyone would argue that the harm worked by a bribe given in the form of a campaign contribution proceeds from or has anything to do with the message to the public the bribe may be used to send.

221 The Supreme Court, however, has upheld a restriction of purely verbal political speech simply because this speech might prompt the sort of favoritism that campaign contributions generate. In United Public Workers v. Mitchell, 330 U.S. 75 (1947), the Court upheld a provision of the Hatch Act that bars executive branch employees other than the president and other high-level officials from engaging in partisan political activity. The challengers of this provision argued that the justifications offered for it did not extend to a federal employee who worked as a "roller in the mint" and neither interacted with the public nor determined policy. The Court replied, "[I]f in free time he is engaged in political activity, Congress may have concluded that the activity may promote or retard his advancement or preferment with his superiors.” Id. at 101. 
First, forbidding an endorsement speech would require someone who favors a candidate to keep his thoughts secret and would deprive the public of important information. ${ }^{222}$ Campaign finance regulation does not require anyone to conceal his thoughts or suppress relevant information.

Second (a related point), the only way to block the conflicts of interest created by endorsement speeches is to forbid them. The conflicts created by campaign contributions and expenditures can be controlled without forbidding them altogether. Outlawing them would in fact be unconstitutional.

Third, even on the implausible assumption that some conflicts of interest could justify forbidding endorsement speeches, no legislator or judge could be trusted with the task of determining which speeches pose a sufficient danger. With campaign contributions and expenditures, no ad hoc evaluation is necessary. Lawgivers can use the metric provided by money to mark the point at which the likelihood of serious conflicts justifies limiting speech. They can draw a bright, workable line to separate the contributions and expenditures that merit protection from those that do not.

Finally, the sense that gifts of money are more corrupting than other favors seems pervasive. This sentiment may inform both the bumpersticker declaration that money is not speech and the Supreme Court's judgment that the First Amendment protects campaign contributions less than other speech.

The law of bribery in fact distinguishes payments of cash (and of goods and services with ascertainable market value) from nonmonetizable personal and political favors. Offering cash to a legislator for his vote is bribery, and so is offering him free yard service for a year. But logrolling - offering to support a proposed bridge in exchange for a legislator's support of widget subsidies-is not bribery. The statement, "I'll contribute to your campaign if you agree to support widget subsidies," is likely to send the speaker to prison. ${ }^{223}$ No one, however, has gone to prison for saying, "I'll make public speeches on your behalf if you agree to support widget subsidies.”224

222 An endorsement speech supplies information about the speaker's state of mind. Only the person who makes the endorsement can supply the information it provides.

${ }^{223}$ See McCormick v. United States, 500 U.S. 257 (1991). The supposed bribe that led to the imprisonment of Don Siegelman, a former governor of Alabama now serving a 6 $1 / 2$-year term, consisted of a contribution to a group supporting a referendum he favored. Possibly pursuant an understanding that preceded the contribution, the governor appointed the contributor to a state board. See United States v. Siegelman, 640 F.3d 1159 (11th Cir. 2011).

${ }^{224}$ Cf. United States v. Singleton, 144 F.3d 1297 (10th Cir. 1999) (en banc) (holding that a prosecutor did not violate a federal bribery statute by offering leniency to 


\section{How Deeply Did Buckley Bury O’Brien?}

When the D.C. Circuit decided Buckley v. Valeo, it declared that O'Brien provided "the pertinent standard" for reviewing campaign finance regulations. $^{225}$ The Supreme Court, however, reversed the D.C. Circuit and declared this standard inapplicable.

The D.C. Circuit offered and the Supreme Court considered only one argument for applying O’Brien-“that the dependence of a communication on the expenditure of money operates itself to introduce a nonspeech element or to reduce the exacting scrutiny required by the First Amendment." ${ }^{226}$ As the Court noted, this argument would have made O'Brien the relevant standard for judging a limitation of the funds that may be used to publish a newspaper. It would have afforded less protection to the spending needed to bring speech to an audience than to the speech itself.

The Court failed to notice that campaign contributions and expenditures differ from the funds used to publish a newspaper. As this Article has observed more than a few times, these contributions and expenditures affect two audiences in two different ways, one of them beneficial and protected by the First Amendment and the other harmful and unprotected. Buckley should not be read as rejecting an argument the Court did not consider.

I do not love the O'Brien standard. Just as some of the language of Citizens United might lead the Supreme Court to protect $\$ 10$ million contributions, ${ }^{227}$ some of O’Brien's language might allow legislatures to prohibit $\$ 200$ contributions. ${ }^{228}$ When speech is combined with conduct

a criminal defendant in return for his testimony against an alleged co-conspirator).

${ }^{225}$ See Buckley v. Valeo, 519 F.2d 821, 840 (D.C. Cir. 1975), aff'd in part and rev'd in part, 424 U.S. 1 (1976).

${ }^{226} \mathrm{Id}$. at 16.

${ }^{227}$ See text at notes supra.

${ }^{228}$ The O'Brien standard has four parts. See 397 U.S. at 376-77.

First, a regulation of speech-conduct must be "within the constitutional power of government." Of course all legislation must be within the constitutional power of government. Whether a regulation falls within the limited powers granted the federal government is a different question from whether it violates the First Amendment. This portion of the test has no purpose except to sound grand.

Second, the regulation must "further an important or substantial governmental interest.” Prohibiting a \$200 campaign contribution does further a substantial governmental interest-the same interest that has led federal and state governments to prohibit $\$ 200$ gratuities to public officials.

Third, the government interest must be unrelated to the suppression of free expression. As argued in the text, it is. 
(or, better, when it produces harms unrelated to the message it sends), an open, un-tilted balance would be better. Nevertheless, courts should recognize that large political contributions do combine speech with conduct or, in the language proposed by John Hart Ely, that the harm these contributions produce is unrelated to the message they deliver. ${ }^{229}$

O'Brien holds that acts combining "speech" and "nonspeech" elements are subject to restriction upon a showing of "an important or substantial governmental interest." 230 Under Buckley, the standard of justification for restricting campaign contributions is similar-a "sufficiently important interest." 231 Recognizing the relevance of O'Brien would be unlikely to affect the Supreme Court's analysis of campaign contributions, but it might alter the Court's analysis of independent electoral expenditures.

This Article focuses on contributions. It proposes no restriction of independent expenditures. The remainder of this Article will consider only how best to apply the Supreme Court's current standards.

\section{A PROPOSED Scheme OF CAMPAIGN FinANCE REgUlation}

\section{A. Tracking Individual Contributions}

According to Buckley, a constitutional regime of campaign finance regulation may not restrict independent expenditures by either individuals or groups. According to Citizens United, such a regime may not limit expenditures on the basis of corporate identity. According to McCutcheon, aggregate contribution limits are generally impermissible; an individual must be allowed to contribute the maximum amount to every candidate in every race.

Nevertheless, the Supreme Court has repeatedly upheld limits on what an individual may contribute to particular candidates, and it has

Fourth, the incidental restriction on alleged First Amendment freedoms must be no greater than is essential to the furtherance of the government's interest. The only way to eliminate conflicts of interest is to forbid conflicts of interest.

Perhaps the O'Brien standard is flexible enough that a court could apply it differently. Especially as applied to campaign finance regulation, however, this test seems insufficiently protective of expression.

229 As Buckley noted, one harm allegedly produced by large campaign contributions - the distortion of election results-may not be independent of the messages the contributions deliver. See Buckley, 434 U.S. at 17. With that possible harm set aside, however, the justification for limiting these contributions does not focus on the messages they deliver.

${ }^{230}$ See O'Brien, 391 U.S. at 377.

${ }^{231}$ See Buckley, 434 U.S. at 30. 
held that measures necessary to enforce these limits are valid as well. Justice Thomas would overrule these precedents, but, in McCutcheon, every other justice proceeded on the assumption that base contribution limits and suitably tailored anti-circumvention measures remain valid.

Campaign finance regulations consistent with these principles would allow individuals and groups to make independent expenditures without restriction. These regulations, however, might limit the amount an individual could contribute to any entity in order to influence the outcome of a single election. ${ }^{232}$ Within this limit, the regulations might allow an individual to allocate his contributions as he liked among whatever groups he liked-campaign committees, party committees, PACs, super PACs, non-profit corporations, for-profit corporations, partnerships, unions, and even biker gangs and churches.

The organizations' ability to accept contributions and make electoral expenditures would be subject to one limitation. They would be required to provide an accounting of which individuals had provided the funds they spent and how the funds each individual had contributed had been allocated to particular races.

An individual could authorize as many organizations as he liked to spend his funds but could not authorize them to spend more together to influence any race than the law allowed. His failure to limit the use of his funds to comply with contribution limits would be subject to sanction, and so would an organization's failure to observe limits it had accepted on the use of a contributor's funds.

People whose total contributions would not exceed the limit for a single race (most people) would have no difficulty allocating their contributions among as many organizations as they liked. Their contributions could be unrestricted. Moreover, a wealthy donor who wished to contribute the maximum amount to, say, every Democratic candidate for federal office could do so, either by contributing this amount to every candidate himself or by making a large contribution to a party organization that would allocate his funds. ${ }^{233}$

Other wealthy donors might make more elaborate arrangements. A donor, for example, might contribute the maximum amount to the candidates he most wished to support and then make an additional

${ }^{232}$ Unlike current election law, which limits the amount an individual may contribute to a group engaged in electioneering, the proposal would limit what an individual may contribute to influence the outcome of a particular election.

${ }^{233}$ McCutcheon rejected the argument that a multi-million-dollar contribution to a party organization or other group supporting multiple candidates itself poses a danger of quid pro quo corruption. The plurality called this argument a "new" rationale for aggregate limits and said that it "dangerously broadens the circumscribed definition of quid pro quo corruption articulated in our prior cases.” McCutcheon, 134 S. Ct. at 1460. 
contribution to a party committee or other political group (say, the Widget Rights Victory Fund) with instructions to use his funds to support any candidates other than those to whom he had already given. Or he might contribute to two political groups with instructions to each of them not to use his funds to give to any single candidate more than $50 \%$ of the maximum an individual might contribute. Conceivably he might instruct a group not to allocate any of his funds to a candidate without checking the public record of his contributions to be sure that doing so would not send his contributions beyond the limit. ${ }^{234}$ A computer could flag unlawful allocations and contributions.

Although the proposed scheme would not have been feasible prior to the computer era, it seems feasible today. Nevertheless, this scheme does pose administrative difficulties. The following sections of this Article will discuss some of these difficulties and also the need to exempt some communications and expenditures from the proposed regulations.

\section{B. Tracking the Money Coming In}

Many organizations cannot trace expenditures from their general treasuries to particular funding sources. The ownership of a publically traded corporation, for example, changes day by day, and many of its shareholders are likely to be collective entities themselves. Moreover, if a publically traded corporation could determine which individuals owned it at the moment it made a particular electoral expenditure, it undoubtedly would find that some of these people had contributed the maximum amount to whatever candidate it supported.

Should the managers of an organization like the Jeckyll Corporation be allowed to find shareholders who have not contributed to Senator Claghorn's campaign and, with their permission, allocate the corporation's expenditure on the senator's behalf to their allowances? The difficulty is that the corporation's expenditure would not reduce these shareholders' wealth by the amount of their supposed contribution. This expenditure would instead diminish the value of every share of the corporation-probably by a trivial amount. ${ }^{235}$ The corporation's

234 The feasibility of this arrangement would depend on whether expenditures could be reported when they were made rather than at the conclusion of a reporting period. There is no apparent reason why a group making expenditures could not update the public record at the same time it updated its own. The public record then would provide a running tally of an individual's contributions to particular candidates. See 2 U.S.C. § 434 (a)(12)(A) (contemplating a computerized tally for contributions made directly to candidate committees).

${ }^{235}$ If Senator Claghorn were to win reelection and then vote for widget subsidies, the investment in his reelection might prove profitable-just as a contribution by an 
expenditure on Senator Claghorn's behalf would proceed from all of its owners, many of whom might have "maxed out."

When the accounting required by the proposed scheme would disable an organization from making electoral expenditures from its general treasury, it could establish a separate political action committee to receive, spend, and account for individual contributions. An organization could pay the administrative expenses of its PAC and could control the PAC's expenditures and contributions.

Proposing the use of PACs may sound both familiar and unpromising. Citizens United held that the ability of corporations to establish PACs did not justify Congress's prohibition of corporate speech. It noted that a PAC is distinct from its creator, and it added, "PACs are burdensome alternatives; they are expensive to administer and subject to extensive regulations." 236 The Court recited many of the regulations applicable to PACs without indicating what, if any, purpose they might serve.

The scheme proposed by this Article, however, differs from the one struck down in Citizens United. It would not prohibit speech on the basis of corporate identity. Any corporation that could comply with the scheme's accounting requirements could make political expenditures from its treasury, and some business corporations (those that could in fact attribute expenditures to individual owners) might do so. In addition, most of the political organizations that tracked individual contributions undoubtedly would be organized as corporations.

Moreover, the burdens imposed by this scheme's accounting requirements would serve a clear and important purpose. They would provide a more straightforward anti-circumvention mechanism than the aggregate limits struck down in McCutcheon. They would in fact constitute the less restrictive alternative McCutcheon demanded. No more direct way of forbidding the circumvention of contribution limits can be imagined than forbidding the circumvention of contribution limits. A court could not strike down the proposed tracking requirements without abandoning the idea of enforceable contribution limits and without overruling decades of precedent.

Although Citizens United permitted large business corporations to make independent electoral expenditures from their general treasuries, they have shown no interest in doing so. ${ }^{237}$ The fact that the proposal

individual donor might prove profitable. The ultimate profitability or unprofitability of a contribution (that is, whether the contribution ultimately turned out to be funded by us taxpayers) does not bear on who made it for purposes of election law.

${ }^{236}$ Citizens United, 558 U.S. at 338.

${ }^{237}$ See text at note supra. 
would effectively require these corporations (along with churches and many other organizations that cannot trace expenditures to particular funding sources) to use separate PACs would not change much, but it might reassure Citizens United's critics.

The proposed scheme might reassure these critics in other ways as well. It would bring the demise of the alter-ego super PAC (a PAC formed simply to further a single candidacy). Such a PAC serves no purpose other than facilitating the evasion of contribution limits. With these limits enforced, almost every donor would prefer to make his donation directly to a candidate. Similarly, the scheme would bring an end to the shadow-party super PAC (a PAC formed to further the interests of a particular party). Again almost everyone would prefer to make his contribution to the real thing.

PACs furthering special interests like the Widget Rights Victory Fund would persist, but they would no longer enable a few wealthy people to pour millions of dollars into particular races. A special interest PAC could swamp its opposition in a particular race only if it received support from a large number of donors.

While allaying the concerns of Citizens United's critics, the proposal would satisfy all of the constitutional requirements articulated by the Supreme Court. Individuals would be allowed to make unlimited electoral expenditures, ${ }^{238}$ and group expenditures also would be unrestricted. As long as a group provided assurance that individual donors had adhered to their own limits, it could spend as much as it could collect. The proposal would not restrict speech on the basis of corporate identity, and it would not impose an aggregate limit on contributions. Anyone with sufficient wealth could contribute the maximum amount to every candidate.

\section{Tracking the Money Going Out}

Under the proposal, a group that distributed an electoral communication urging voters to support multiple candidates in multiple races ("vote Republican" or "support these pro-widget candidates") would be required to apportion the cost of producing and distributing this communication among the candidates. If the communication featured some candidates more prominently than others, the group might be required to apportion costs on the basis of the airtime or print space allocated to each.

Apportioning a group’s general administrative expenses among the

\footnotetext{
${ }^{238}$ For a discussion of whether these expenditures would greatly reduce the value of the scheme, see text at notes infra.
} 
candidates it supported (and between the group's electoral and nonelectoral activities) also might be necessary, ${ }^{239}$ but the effectiveness of the scheme would not be greatly diminished if these expenses were exempted from contribution limits and tracking requirements.

\section{Exemptions}

The proposed regime of campaign finance regulation would be unconstitutional without at least one exemption. Its restrictions should not apply to the funds used to produce and disseminate "any news story, commentary, or editorial distributed through the facilities of any broadcasting station, newspaper, magazine, or other periodical publication."240 A newspaper publisher should be allowed to print an editorial endorsing a candidate without supplying an account of how much the publication cost and what each of the newspaper's shareholders had contributed to this expenditure.

The exemption of the institutional press from campaign finance regulations would not rest on an interpretation of the First Amendment that afforded the press special privileges. It would rest instead on the factual differences between editorial endorsements and the electoral communications that warrant restriction. ${ }^{241}$

239 The proration of general administrative expenses seems feasible. See Carey v. FEC, 791 F. Supp. 2d 121 (D.D.C. 2011) (holding that a single group may operate as both a conventional PAC and a super PAC if it segregates the funds it uses for contributions to candidates from those it uses to place advertisements of its own and if it apportions administrative expenses between these two activities).

${ }^{240}$ The suggested language comes from a statutory exemption to the regulations that Citizens United struck down. 2 U.S.C. § 431(9)(ii)(B)(i). A publication owned or controlled by a political party, PAC, or candidate was not entitled to this exemption. Id.

${ }^{241}$ Michael McConnell's recent defense of the result in Citizens United consisted of two propositions: (1) The First Amendment affords a newspaper publisher the right to print an editorial endorsing a candidate; and (2) the First Amendment affords no greater right to the newspaper publisher than to the rest of us, including the plaintiff in Citizens United. Michael W. McConnell, Reconsidering Citizens United as a Press Clause Case, 123 YALE L.J. 412 (2013).

The Citizens United dissenters briefly questioned the second proposition. They wrote that when corporations "are part of the press," they may be entitled to "special First Amendment status.” Citizens United, 558 U.S. at 431 n.57 (Stevens, J., dissenting). The majority responded, "WWe have consistently rejected the proposition that the institutional press has any constitutional privilege beyond that of other speakers." Id. at 352 (majority opinion) (quoting Austin v. Michigan Chamber of Commerce, 494 U.S. 652, 691 (1990) (Scalia, J., dissenting)).

McConnell and the Citizens United majority had the better of this argument. The First Amendment affords all of us the right to speak and publish. It does not give the pros special privileges. See Lovell v. Griffin, 303 U.S. 444, 452 (1938) (“The liberty of 
Although electoral advocacy is what campaign committees and super PACs do, it is a small part of what most regularly published newspapers and television stations do. Because electoral advocacy is central to the mission of campaign committees and super PACs, wealthy people contribute to these organizations in the hope of gaining influence over elected officials. Wealthy people rarely buy newspapers or television stations because they consider owning these outlets the best way to gain the favor of public officials. Newspaper publishers are much less likely than super PAC contributors to be clout seekers.

Moreover, newspaper endorsements generally evaluate a candidate's stands on many issues. They usually are unaccompanied by an indication of a personal or organizational interest they hope the favored candidate will support. A newspaper publisher is unlikely to follow an editorial endorsement with a request for a meeting so that it can urge the candidate it endorsed to take an action it favors. The publisher is also unlikely to hire a lobbyist. A newspaper's endorsements differ greatly in both purpose and effect from the advertisements placed by campaign committees and super PACs.

Feature films, books, and monographs (defined, perhaps, as written communications of more than 10,000 words or spoken or film communications of longer than 70 minutes) also might be exempted from campaign finance regulations. During the initial argument of Citizens United, a deputy solicitor general responded to questions from the bench by saying that a corporation could be prohibited from publishing a book if the book's last sentence endorsed a candidate. This answer did not advance his cause. ${ }^{242}$

Even without an exemption for books, films, and monographs, the regulatory scheme proposed in this Article would not prohibit anyone from publishing anything. It would merely limit how much an individual could contribute to a group for the purpose of publishing books and other things that qualified as electoral communications.

There would be almost as little reason, however, to restrict the financing of books, feature films, and monographs as to restrict the publication of newspapers. The suggested scheme would remain effective

the press is not confined to newspapers and periodicals. . . . [It] comprehends every sort of publication which affords a vehicle of information and opinion.”); Pennekamp v. Florida, 328 U.S. 331, 364 (1946) (Frankfurter, J., concurring) (“[T]he purpose of the Constitution was not to erect the press into a privileged institution but to protect all persons in their right to print what they will as well as utter it.”).

The speech of all of us, however, is subject to restriction when it poses a sufficient danger of corrupting public officials. Large contributions to candidates and super PACs pose a sufficient danger; newspaper editorials do not.

${ }^{242}$ See Toobin, supra note (describing counsel’s argument as “an epic disaster”). 
if it reached only more familiar sorts of campaign communicationsbroadcast and print advertisements, billboards and other signs, direct mailings, and pamphlets or recordings distributed on the street or doorto-door. Books, films, and monographs ordinarily are distributed to purchasers and/or others who have indicated an interest in receiving their messages. Because effective electioneering requires reaching less involved audiences, political campaigns rely almost entirely on other media. ${ }^{243}$

\section{E. Independent Expenditures}

Daniel Ortiz has observed that the distinction between campaign contributions and independent expenditures is the most troubling and most often criticized aspect of the Supreme Court's campaign finance jurisprudence. ${ }^{244}$ Michael McConnell has commented that this distinction "pleases no one." 245 Six justices of the Supreme Court would in fact abandon the distinction. Because three of them would abolish it by increasing the protections afforded contributions and three would abolish it by reducing the protections afforded expenditures, however, the distinction persists. ${ }^{246}$

Although the Supreme Court's arguments for distinguishing contributions from expenditures may not convince many, ${ }^{247}$ the distinction expresses the common intuition that writing a check is less worthy of protection than actually speaking. ${ }^{248}$ It also marks in a rough way where serious conflicts of interest are likely to arise. It is the checkwriters, not the speakers or the spenders, who may have given America its intricate tax code, its sugar subsidies, its armaments approved by Congress despite opposition by the Pentagon, and a public health care system that accommodates the interests of pharmaceutical and insurance

243 Other exemptions from the scheme might be designed to reduce its administrative burdens. For example, a group whose treasury included individual membership dues of no more than, say, $\$ 75$ per year should not be required to include these dues in its account of individual contributions.

244 Daniel R. Ortiz, Election Law as Its Own Field of Study: From Rights to Arrangements, 32 LOY. L.A. L. REV. 1217, 1223 (1999).

245 See McConnell, supra note , at 451.

246 See id. (citing Nixon v. Shrink Mo. Gov't PAC, 528 U.S. 337, 409-10 (2000) (Kennedy, J., dissenting); id. at 410 (Thomas, J., dissenting, joined by Scalia, J.); American Tradition Partnership v. Bullock, 132 S. Ct. 2490, 2491-92 (2012) (Breyer, J., dissenting, joined by Ginsburg, Sotomayor, \& Kagan, JJ.)).

${ }^{247}$ See text at notes infra (reviewing these arguments and noting that all but one of them apply equally to super PAC contributions).

248 See text at supra. 
companies as well as the public. ${ }^{249}$

This section will consider how to draw the line between contributions and expenditures. It then will consider whether independent expenditures would seriously diminish the effectiveness of the proposed regulatory scheme.

\section{Drawing the Line}

The distinction between contributions and expenditures rests on the premise that financing speech differs from speaking. The financing may be restricted even when the speech may not. When Person A writes a check and Person B determines what speech the check will finance, Person A's activity may be limited, but Person B's may not. As the plurality opinion observed in California Medical Ass'n v. FEC, ${ }^{250}$ “'[S]peech by proxy' . . . is not the sort of political advocacy that this Court in Buckley found entitled to full First Amendment protection." 251

The Supreme Court has not indicated how much separation between financier and speaker is necessary before the financier's activity may be restricted. Under Buckley's analysis, a wealthy person's purchase of space in a newspaper to publish his own list of reasons for supporting a candidate would be a paradigmatic independent expenditure and would be fully protected. Moreover, his expenditure would remain independent and protected if other people joined him in composing the list and buying the space. Something more than writing a check to a group is required, however, and the "something more" probably cannot be merely symbolic (something like filling out a questionnaire that super PAC managers might or might not take into account). When "[t]he transformation of contributions into political debate involves speech by someone other than the contributor," Buckley indicates the contributions may be limited. ${ }^{252}$

Assessing the degree of separation between speaker and financier on a highly fact-specific basis would be impractical. A wealthy person might pay a veteran campaign operative to write and place advertisements supporting a candidate and might give this person funds to spend as he chose. If the financier did not supervise the work of this operative at all, he would look like a contributor rather than a speaker. He would have funded "speech by someone other than" himself. If, however, the campaign veteran served only as an advisor to the wealthy person, the

\footnotetext{
249 The political operatives who collect and spend donated funds rarely seek more for themselves than new political jobs.

250453 U.S. 182 (1981).

${ }^{251} I d$. at 196.

${ }^{252}$ See Buckley, 424 U.S. at 21.
} 
wealthy person's expenditures would remain independent. Drawing the line between contribution and expenditure by determining which person was the "real" speaker does not seem feasible.

A more workable system would resolve the separation issue formally. Under this regime, any use of a person or legal entity other than the financier himself to make an expenditure would put his spending in the "contribution" rather than the "expenditure" category. If the financier ultimately made the expenditures himself, he could hire as many people as he liked to help him prepare and disseminate his messages. The financier, however, would be required to take public responsibility for these messages: “I'm Pierpont Mogul, and I approved this message.”"253

2. How Big is the Loophole?

\section{a. Groups}

If the amount individuals could contribute to organizations to influence the outcome of particular elections were effectively limited, limiting expenditures by the organizations themselves would serve no important purpose.

Without accepting any contributions, the National Widget Association or its PAC could advise members to include reminders of their association membership when they sent their individual checks. It also could advise them where their contributions would be most likely to advance the cause of widget rights. ${ }^{254}$ Forbidding the Association to accept, bundle, and spend its members' contributions would merely make members who sought to coordinate their contributions less efficient in doing so.

A cap on the Widget Association's expenditures, moreover, would not notably impede its members' ability to coordinate their contributions. It simply would lead to the formation of a second PAC to receive and spend the contributions the first PAC could not spend. Little would be gained by

253 See Buckley, 424 U.S. at 60-68 (upholding disclosure requirements); Citizens United, 358 U.S. at 366-71 (same). Nothing would prevent a financier from acting jointly with others, but each of the joint actors would be required to take responsibility as an individual for the group's message. If these actors were to form a distinct legal entity to make their expenditures, they would all become contributors, and their contributions would be subject to reasonable limitation.

254 The first political action committee made no political contributions. This committee, which the CIO formed in 1944, simply urged union members to contribute to President Roosevelt's reelection campaign. See Manny Calavera, The Effectiveness of Corporate PAC Expenditures and Their Role in the Legislative Process, YAHOO VOICES, Apr. 13, 2007, http://voices.yahoo.com/the-effectiveness-corporate-pacexpenditures-and-283948.html?cat=37. 
mandating the formation of two groups, the National Widget Association Political Action Committee and the Widget Rights Victory Fund.

\section{b. Individuals}

Dissenting in FEC v. National Conservative Political Action Committee $^{255}$ eight years after Buckley, Justice Marshall confessed that he had erred in Buckley when he endorsed the distinction between contributions and expenditures. He wrote:

It does not take great imagination . . . to see that, when the possibility for direct financial assistance is severely limited, as it is in light of Buckley's decision to uphold the contribution limitation, .... an individual [seeking favor] will find other ways to financially benefit the candidate's campaign. It simply belies reality to say that a campaign will not reward massive financial assistance provided in the only way that is legally available. $^{256}$

The Supreme Court later observed in McConnell v. FEC, "Money, like water, will always find an outlet."257

Experience, however, has not validated the hydraulic hypothesis. ${ }^{258}$ Justice Marshall provided no illustrations of clout-seeking individuals who had made "massive" individual expenditures to evade contribution limits, and illustrations are almost as rare today. ${ }^{259}$

Two other ways around contribution limits, both antedating Citizens United, might have made independent expenditures by individuals unnecessary. Unlike independent expenditures, donations to 527 and

255470 U.S. 480 (1984).

${ }^{256}$ Id. at 519 (Marshall, J., dissenting).

${ }^{257}$ McConnell v. FEC, 540 U.S. 93, 224 (2003).

${ }^{258}$ But see Samuel Issacharoff \& Pamela S. Karlan, The Hydraulics of Campaign Finance Reform, 77 TEX. L. REV. 1705, 1708 (1999) ("First, we think political money, like water, has to go somewhere. It never really disappears into thin air. Second, we think political money, like water, is part of a broader ecosystem.").

${ }^{259}$ Don Blankenship, the chairman and chief executive officer of the Massey Coal Company, did spend $\$ 500,000$ from his own pocket to influence the outcome of a West Virginia judicial election, but he donated five times more- $\$ 2.5$ million-to a PAC to influence the same election. See Caperton v. A. T. Massey Coal Co., 556 U.S. 868 (2009); text at notes infra. I am unaware of anyone other than Blankenship who has made a $\$ 500,000$ independent expenditure to support a candidacy other than his own, and a candidate who uses his own wealth to advance his campaign does not corrupt himself. See Buckley, 424 U.S. at 51-54 (striking down a statutory limit on independent expenditures by candidates). 
501(c)(4) groups demanded no more of a favor seeker than that he write a check. ${ }^{260}$ A check to one of these groups, however, was likely to be less effective than a check to an official campaign committee in producing clout. ${ }^{261}$ Before Citizens United, money given to either sort of group could not be used to advocate a candidate's election directly; the group was required to cast its advocacy as commentary on a political issue. ${ }^{262}$ And half of the money given to a 501(c)(4) group could not be used even for issue advertisements if they were intended to influence an election. ${ }^{263}$

Citizens United and SpeechNow cast aside the limitations of earlier work-arounds. These decisions together created a new way of evading contribution limits that did not differ much from blowing up the limits altogether. And after SpeechNow came the deluge.

The enormous increase in large individual contributions that followed SpeechNow revealed that campaign finance law makes a difference. ${ }^{264}$ The amount of political money devoted to influence buying is not fixed. Some loopholes are larger than others. Before Citizens United and SpeechNow, some cynics pointed to leakage and called the dam useless. They were proven to have exaggerated when SpeechNow demolished the dam.

Independent expenditures are a particularly unlikely and unattractive work-around. Even someone willing to write a $\$ 10$ million check to a super PAC probably would balk when invited to support a campaign by using the same funds to hire and manage a satellite campaign staff of his own and by taking personal responsibility for the messages it sent. If (remarkably) this financier did agree to make independent personal

${ }^{260}$ See 26 U.S.C. §§ 527 \& 501(c)(4).

${ }^{261}$ It was also likely to be less effective in persuading the public.

${ }^{262}$ During John Kerry's 2004 presidential campaign, Swift Boat Veterans for Truth registered as a 527 group. The Federal Election Commission later concluded, however, that it did not qualify and had violated election laws by failing to observe contribution limits. See Federal Election Commission, Press Release: FEC Collects \$630,000 in Civil Penalties from Three 527 Organizations, Dec. 16, 2006, http://www.fec.gov/press/press2006/20061213murs.html. Today, following Citizens United and SpeechNow, there are no limits. A group like Swift Boat Veterans for Truth would have no reason to mask its electoral purpose even slightly.

${ }^{263}$ 501(c)(4) or "dark money” groups are tax-exempt organizations whose earnings are devoted to charitable, educational, or recreational purposes. See 26 U.S.C. § 501(c)(4). The Internal Revenue Service has ruled that these groups may "intervene in political campaigns as long as [their] primary activity is the promotion of social welfare.” INTERNAL REVENUE MANUAL 7.25.4.7. Like the super PACs that devote all of their efforts and funds to campaigning, 501(c)(4) groups may operate as "independent expenditure groups." When they do, SpeechNow allows them to collect and spend unlimited amounts supporting and opposing candidates. Unlike PACs and 527 groups, 501(c)(4) groups need not report publically the identity of their contributors.

${ }^{264}$ See text at notes supra. 
expenditures on behalf of a candidate, one of the dubious things Buckley said about these expenditures might become true: "Unlike contributions, . . . independent expenditures may well provide little assistance to the candidate's campaign and indeed may prove counterproductive.”265 Although independent expenditures provide a path around individual contribution limits, few contributors would be likely to take it.

\section{CONCEPTS OF CORRUPTION ${ }^{266}$}

\section{A. Two-Part Typologies}

In Citizens United, the Supreme Court noted that Buckley v. Valeo had treated only one interest as "sufficiently important" to justify a restriction of campaign contributions - "the prevention of corruption and the appearance of corruption."267 The Court added, "When Buckley identified a sufficiently important governmental interest in preventing corruption or the appearance of corruption, that interest was limited to quid pro quo corruption." 268

The Court explained what quid pro quo corruption is not. "Ingratiation and access . . . are not corruption,"269 it said. "The fact that speakers may have influence over or access to elected officials does not mean that these officials are corrupt." 270 The Court also offered a positive definition: "The practices Buckley noted would be covered by bribery laws if a quid pro quo arrangement were proved." 271 This sentence indicated that quid pro quo corruption meant bribery and nothing else.

${ }^{265}$ Buckley, 424 U.S. at 47. Living rooms in battleground states might resound with the voices of George Soros, Sheldon Adelson, and Charles and David Koch (in unison) noting their approval of political advertisements.

266 The Supreme Court allows limitations of speech in order to reduce either corruption or the appearance of corruption, and the word appearance has myriad meanings. See Adam M. Samaha, Regulation for the Sake of Appearance, 125 HARV. L. REV. 1563 (2012). Presumably the appearance of corruption is not "anything that smells a bit like corruption"; it is instead "something that is believed or suspected to be corruption.” Moreover, the corruption that is suspected must be of the kind that justifies regulation, and an unreasonable belief or suspicion in the existence of this corruption probably cannot justify limiting speech. The appropriate remedy for an unfounded belief is usually "more speech." Thus the appearance of corruption probably means "something that is reasonably believed or suspected to be corruption of the sort that justifies regulation" or "something that might in fact be corruption of the sort that justifies regulation."

${ }^{267}$ Buckley, 424 U.S. at 25.

${ }^{268} \mathrm{Id}$. at 909.

${ }^{269} \mathrm{Id}$.

${ }^{270}$ Citizens United, 558 U.S. at 360.

${ }^{271} I d$. at 908 (citation to 18 U.S.C. $\S 201$, a federal bribery statute, omitted). 
Corruption in its classic sense describes something that has become impure or perverted. When people speak of corrupted computer files and corrupted chemical solutions, for example, they do not mean that the computer files and chemical solutions take bribes.

Plato, Aristotle, and other ancient philosophers spoke of corrupted government in a similar way. Corruption meant departure from an imagined state of perfection. Corruption was a matter of degree, not yes or no, and every real-world government was to some degree corrupt. ${ }^{272}$

Aristotle described the most common type of corruption: "The true forms of government ... are those in which the one, the few, or the many govern with a view to the common interest; but governments which rule with a view to the private interest . . . are perversions." ${ }^{273}$ On the assumption that a public official's duty is to advance the public good, ${ }^{274}$ everything that diverts him from serving the public - every conflict of interest-corrupts.

As Zephyr Teachout has shown, the framers of the Constitution often used the word corruption in its classic sense. They regarded limiting the corruption that arises from the private interests of both elected officials and the voters who choose them as one of their central missions. ${ }^{275}$

Today's dictionaries, however, do not place the classic definition first

272 Richard Mulgan nicely develops this point in Richard Mulgan, Aristotle on Legality and Corruption, in CORRUPTION: EXPANDING THE FOCUS 25 (Manuhuia Barcham, Barry Hindess, and Peter Lamour, eds., 2012).

${ }^{273}$ ARISTOTLE, Politics 59 (Benjamin Jowett, tr.) (Forgotten Books ed. 2007).

${ }^{274}$ Sadly, some theorists dismiss Aristotle's concept of the public good. They not only embrace pluralism as a description how American politics operates but also romanticize group greed. An influential early work is ARTHUR F. BENTLEY, THE PROCESS OF GOVERNMENT: A STUDY OF SOCIAL PRESSURES (1908).

${ }^{275}$ See Zephyr Teachout, The Anti-Corruption Principle, 94 CORNELL L. REV. 341 (2009).

The Constitution structured the federal government to minimize the temptation and ability of officials to subvert the public good. See, e.g., THE FEDERALIST No. 57, at 343 (Madison) (Isaac Kramnick ed., 1987) (declaring that "the genius of the whole system" would limit "legal discriminations in favor of . . . a particular class of the society"); 4 Debates in the Several State Conventions on the Adoption of the Federal Constitution 302 (Jonathan Elliot ed., 1836) (remarks of Charles Pinckney) ("[C]orruption was more effectually guarded against, in the manner this government was constituted, than in any other that had ever been formed.").

In addition, the Constitution forbade a few specific conflicts of interest. It barred the appointment of present and former members of Congress to offices that had been created or whose compensation had been increased while they were in office, U.S. Const., Art. I, \& 6, cl. 2, and it prohibited office holders from accepting gifts or titles "of any kind whatever" from kings, princes, and foreign governments without the consent of Congress, U.S. ConsT., Art. I, § 9, cl. 8. The foreign emoluments clause has no exception for campaign contributions. 
on their list. Their first definition of corruption usually is: "guilty of dishonest practices, as bribery; without integrity, crooked: a corrupt judge."276

Scholars like Teachout and Lawrence Lessig have regarded the Supreme Court's distinction between quid pro quo corruption and all other corruption as matching roughly the distinction between dishonestconduct corruption and classic corruption. ${ }^{277}$ Further disaggregation, however, might be instructive. Quid pro quo corruption is less than classic corruption, but, despite a sentence in Citizens United that appears to say the contrary, it might encompass more than bribery.

\section{B. Understanding Quid Pro Quo Corruption}

\section{A Four-Part Typology}

Consider four types of behavior the proponents of campaign finance regulation might call corrupt-the explicit exchange of favorable governmental action for campaign contributions (explicit agreement), the implicit understanding that favorable action will follow contributions (implicit agreement), the conscious taking of favorable action in response to contributions without any prior agreement or understanding (conscious favoritism), and affording gratitude and access to contributors without consciously favoring them in making more substantial decisions

\footnotetext{
276 The Random House College Dictionary 302 (rev. ed. 1975); see OXFORD DICTIONARIES ONLINE (U.S. ENGLISH), http//oxforddictionaries.com/definition/american_english/corrupt?region=us (defining corrupt as "having shown a willingness to act dishonestly in return for money"); LAWRENCE LESSIG, REPUBLIC, LOST: HOW MONEY CORRUPTS CONGRESS-AND A PLAN TO STOP IT 226 (“The ordinary meaning of corruption-at least when we're speaking of government officials, or public institutions-is clear enough. Corruption means bribery.”).

277 Lessig distinguishes dishonest-conduct corruption from what he calls “dependence corruption." "Dependence corruption” looks a lot like classic corruption, but it may not encompass everything that diverts public officials from advancing the public good. It may refer only to substantial conflicts of interest that create long-term dependencies. Lessig argues that the Framers of the Constitution intended elected officials to be dependent only on the people. Today, he says, candidates must survive a "money primary" and have become dependent on a narrow class of wealthy donors as well. LESSIG, supra note, at 15-20, 230-47. See also Lawrence Lessig, What an Originalist Would Understand "Corruption" to Mean: The 2013 Jorde Lecture, 102 CAL. L. REV. _ (2013) (forthcoming); "Corruption," originally, http://ocorruption.tumblr.com (undated: "a blog collecting every use of the term 'corruption' among the records of the Framers. Submitted to the Supreme Court as an appendix to an amicus brief by Lawrence Lessig for the Constitutional Accountability Center”).
} 
(preferential access).

Citizens United's concept of quid pro quo corruption unmistakably includes explicit agreement and unmistakably excludes preferential access. It almost certainly includes implicit agreement as well. Whether it includes conscious favoritism, however, is problematic. Although the Court's signals were conflicting, this Article will argue that the Court's concept of quid pro quo corruption should be understood to encompass this favoritism. A public official who deliberately provides a governmental benefit because he has received a private benefit should be seen as returning "this for that" (or quid pro quo) despite the absence of an earlier agreement to do so.

\section{Preferential Access}

Selling access is not good government. Aristotle and the Framers of the Constitution would not have balked at calling it corrupt. As Representative Romano Mazzoli observed, "Access is power. Access is clout." ${ }^{278}$ Campaign contributors do not seek access simply because they enjoy chatting. They seek it because it produces outcomes they like. Officials cannot be persuaded by arguments they do not hear. Moreover, it is difficult for officials to refuse the requests of people who have placed them in office. Officials may strive earnestly to benefit the public, but their unconscious favoritism is favoritism too.

Affording special access to contributors is nevertheless a routine and acknowledged feature of American politics. Barack Obama wrote of the "people of means" he met at Democratic fundraisers, "As a rule they were smart, interesting people ... expecting nothing more than a hearing of their opinions in exchange for their checks." ${ }^{279}$ An email sent by the Mitt Romney presidential campaign declared:

The campaign is asking people who are able to make a $\$ 50,000$ contribution to do so today and become a "Founding Member" of Romney Victory. These donors will be invited to a special retreat with Governor Romney in late June in California and will have preferred status at the first Presidential Inaugural retreat as well as yet to be determined access at the Republican

\footnotetext{
278 Democracy Matters, What Do Elected Officials Think About the Role of Money in Politics?, http://www.democracymatters.org/what-you-need-to-know-about-moneyin-politics-2/overview/what-do-elected-officials-think-about-the-role-of-money-inpolitics/ (last visited Jan. 2, 2014) (quoting Representative Mazzoli).

${ }^{279}$ BARACK OBAma, THE AUDACITY OF Hope: ThOUghtS ON REClaiming THE AMERICAN DREAM 114 (2006).
} 
One need not applaud affording special access to contributors to conclude that this practice is now ingrained and that interest in preventing it cannot justify any limitation of political contributions and expenditures. Citizens United's position on the least troubling of the four types of corruption was clear and plausible. As the McCutcheon plurality reiterated, "[G]overnment regulation may not target the general gratitude a candidate may feel toward those who support him or his allies, or the political access such support may afford." 281

\section{Explicit and Implicit Agreement}

An implicit understanding or agreement to trade campaign cash for government benefits does not constitute criminal bribery. The Supreme Court held in McCormick v. United States ${ }^{282}$ that, unlike other payments, campaign contributions may be treated as bribes only when "the payments are made in return for an explicit promise or undertaking by the official to perform or not to perform an official act." ${ }^{283}$ Although the Eleventh Circuit has concluded (dubiously) that a later Supreme Court decision modified McCormick, ${ }^{284}$ at least six other courts of appeals

${ }^{280}$ Ben Smith, Exclusive: Romney Sells Inauguration Access, Nine Months Early, BuzzFeED Politics, Apr. 16, 2012, http://www.buzzfeed.com/bensmith/romney-sellsinauguration-access-nine-months-earl (reprinting the email in full). See also Democracy Matters, supra note (reciting public acknowledgements by Members of Congress that they afford special access to contributors).

In United States v. Carpenter, 961 F.2d 824 (9th Cir. 1992), the Ninth Circuit rejected the government's claim that a state legislator violated the Hobbs Act by affording access in exchange for campaign contributions. It wrote:

[T]here are several times as many lobbyists in Sacramento as there are state legislators. Elected officials must ration their time among those who seek access to them and they commonly consider campaign contributions in deciding how to ration their time. This practice "has long been thought to be well within the law [and] in a very real sense in unavoidable.” . . . Accordingly, we hold that granting or denying access to lobbyists based on levels of campaign contributions is not an "official act" . . . and cannot, by itself, form the basis for a charge of extortion or attempted extortion under the Hobbs Act.

Id. at 827 (quoting McCormick v. United States, 500 U.S. 257, 272 (1991)).

${ }^{281}$ McCutcheon, 134 S. Ct. at 1441.

282500 U.S. 257 (1991).

${ }^{283}$ Id. at 273 (emphasis added).

284 See United States v. Siegelman, 640 F.3d 1159, 1171 (11th Cir. 2011) 
insist that an explicit agreement remains necessary. ${ }^{285}$ If Citizens United's statement that quid pro quo corruption means criminal bribery were to be taken literally, an implicit understanding that government favors would follow a campaign contribution would be insufficient.

The majority opinion in Citizens United, however, included several statements that probably should not be read literally, and the declaration that "[t]he practices Buckley noted would be covered by bribery laws if a quid pro quo arrangement were proved" 286 is one of them.

Justice Kennedy, the author of the Citizens United opinion, would in fact abandon McCormick as a measure of criminal bribery. In a concurring opinion one year after McCormick, he wrote that a public official and his benefactor "need not state the quid pro quo in express terms, for otherwise the law's effect could be frustrated by knowing winks and nods." ${ }^{287}$ It seems unlikely that Citizens United meant to exclude from the category of quid pro quo corruption conduct that Justice Kennedy himself would treat as felonious.

Moreover, the reasons for applying a special standard of bribery to campaign contributions do not apply to campaign finance regulations. Whenever an elected official adheres to the positions that prompted voters and contributors to support him, he exhibits a pattern of favoritism for these supporters. This pattern may bespeak conviction, not corruption. Ambitious prosecutors and cynical jurors, however, can easily infer a corrupt agreement from the common pattern. When an official has supported widget subsidies after accepting large contributions from widget manufacturers, for example, prosecutors and jurors may infer that there must have been an implicit understanding. Allowing inferences of this sort whenever officials have acted to benefit contributors could make public life intolerable. As Justice Kennedy's reference to winks and nods suggests, it grates that McCormick places a premium on indirection, but the alternative probably would be worse.

When legislatures address the risk of corruption by enacting specific ex ante regulations rather than by inviting jurors to draw ex post inferences of unspoken agreement, the concerns that justify McCormick disappear. In the context of ex ante regulation, it is difficult to fathom

(discussing Evans v. United States, 504 U.S. 255 (1992)).

285 See United States v. Turner, 684 F.3d 244, 253-54, 258 (1st Cir. 2012); United States v. Ganim, 510 F.3d 134, 142-43 (2d Cir. 2007); United States v. Antico, 275 F.3d 245, 256-61 (3d Cir. 2001); United States v. Abbey, 560 F.3d 513, 515-19 (6th Cir. 2009); United States v. Giles, 246 F.3d 966, 971-72 (7th Cir. 2001); United States v. Kincaid-Chauncey, 556 F.3d 923, 936-37 (9th Cir. 2009).

${ }^{286} \mathrm{Id}$. at 908.

${ }^{287}$ Evans, 504 U.S. at 274 (Kennedy, J., concurring). 
any reason for excluding wink-and-nod agreements from the concept of quid pro quo corruption, and the Supreme Court probably did not mean to exclude them.

\section{Conscious Favoritism}

Did the Court mean to exclude conscious favoritism? Again, the statement that quid pro quo corruption means bribery suggests that it did. Conscious favoritism does not constitute bribery even when the alleged bribe consists of something other than a campaign contribution. Bribery requires at least an implicit agreement at the time the alleged bribe is received. ${ }^{288}$

The Court reinforced the sense that conscious favoritism was "out" when it wrote, "[F]ew if any contributions to candidates will involve quid pro quo arrangements." 289 Favoritism, unlike bribery, requires no "arrangement" and does not appear to be rare. ${ }^{290}$ The Court also spoke directly of favoritism, declaring that " "[f]avoritism and influence are not . . . avoidable in representative politics"” and that a "generic favoritism or influence theory is at odds with standard First Amendment analyses because it is unbounded and susceptible to no limiting principle.",291 These statements all indicated that deliberate favoritism for donors did not constitute the kind of corruption that could justify limiting campaign contributions and expenditures.

Citizens United might have pointed in the other direction when it said, "If elected officials succumb to improper influences from independent expenditures; if they surrender their best judgment; and if they put expediency before principle, then surely there is cause for concern.” 292 The import of this statement, however, was unclear. Did it indicate that reducing improper influence was an appropriate goal of campaign finance regulation? Or did the Court merely say, "Be concerned about improper influence, but don't imagine that you can do anything about it; the First Amendment as we understand it declares every cure for the favoritism produced by political contributions and

288 See, e.g., id. at 268 (majority opinion) ("The offense is complete at the time when the public official receives a payment in return for his engagement to perform specific official acts.”). Bribery also includes what might be called attempted agreements - solicitations by a single party and transactions in which one party merely feigns agreement. Favoritism, however, is insufficient. See, e.g., 18 U.S.C. § 201(b).

${ }^{289}$ Citizens United, 558 U.S. at 908.

290 See Appendixes B, C, D, and E to this article.

291 Citizens United, 558 U.S. at 359 (quoting McConnell v. FEC, 540 U.S. 93, 297

(2003) (Kennedy, J., dissenting)).

${ }^{292} \mathrm{Id}$. at 361. 
expenditures worse than the disease”? ${ }^{293}$ After the Court acknowledged that concern was appropriate, it said, "The remedies enacted by law . . . must comply with the First Amendment; and, it is our law and our tradition that more speech, not less is the governing rule. An outright ban on corporate political speech during the critical preelection period is not a permissible remedy." 294

If conscious favoritism is "out," not only bans of corporate speech but also all other remedies that limit contributions and expenditures are impermissible. The Court's view is that only the actuality or appearance of quid pro quo corruption can justify any limitation of speech. Citizens United might have disabled Congress from addressing the favoritism generated by contributions and expenditures in the only appropriate way - through specific ex ante regulation.

Definitions of bribery exclude conscious favoritism, not because the practice is legitimate, but because turning 15-year prison sentences on ex post assessments of motive would be frightening. Inferring favoritism is even easier than inferring unexpressed agreement. If an official were subject to lengthy imprisonment whenever a jury could be persuaded that he had acted deliberately to benefit a campaign contributor or other benefactor rather than the public, only a fool would take the job.

The judgment that favoritism should not be regulated through ex post judgments of motive does not imply that it should not be regulated at all. When ex ante campaign finance regulation is forbidden, legislators, prosecutors, and lower federal courts may press for the expansion of less satisfactory criminal remedies. For example, they may widen the bribery net to include practices with ominous names that, as defined (or as left undefined), are likely to sweep in legitimate conduct-undisclosed conflicts of interest, deprivations of the intangible right to honest services, and undisclosed self-dealing. ${ }^{295}$ If precise ex ante regulations were to wane while ex post judgments of motive waxed, the law would get things backwards.

Concluding that conscious favoritism does not qualify as quid pro quo corruption not only would block the most appropriate way of curbing this practice; it also would narrow the government's regulatory interest to the point that it might not justify even the limits on contributions the

\footnotetext{
293 Or perhaps: "Don’t imagine that you can do anything about it except elect saints to office."

${ }^{294}$ Id. Note the Court's failure to recognize the difference between the two sorts of persuasion emphasized by this Article. "More speech" is not a plausible remedy for a harm not produced by speech. In the absence of a governmental corrective, the only plausible remedy for the purchase of favoritism with cash is "more cash."

295 See Albert W. Alschuler, Terrible Tools for Prosecutors: Notes on Senator Leahy's Proposal to “Fix” Skilling v. United States, S.M.U. L. REV. (2014).
} 
Court left intact.

The interest in combatting bribery cannot justify campaign finance regulations because that's not the way things are done. Campaign contributions rarely buy promises of favorable governmental action; they buy influence. Moreover, even the interest in preventing the appearance of bribery cannot justify campaign finance regulations, because everyone knows that's not the way it's done.

The problem is not that donors and candidates fail to spell everything out. It is not that their agreements usually are left to winks, nods, and implication. The problem is that, with rare exceptions, there are no agreements, express or implied. Contributions are accompanied by hope but not by an understanding that a candidate will provide anything in return. The hope may turn out to be justified often enough to make the contributions good investments. Citizens United observed, "[F]ew if any contributions to candidates will involve quid pro quo arrangements."296 Criminal "arrangements" are rare both because they are criminal and because they are unnecessary. A rare or nonexistent practice cannot justify a sweeping restriction of speech. ${ }^{297}$

Even if bribery were more frequent than it is, campaign finance regulations would do little to stop it. People willing to violate bribery laws are willing to violate campaign finance regulations too. Enforcing the campaign finance regulations is usually not much easier than enforcing the law against bribery. ${ }^{298}$ A small tail would wag a huge mastiff if reducing bribery were to become the only permissible reason for campaign finance regulation.

Excluding conscious favoritism from the realm of quid pro quo corruption not only might block the most appropriate form of regulation and narrow the government's regulatory interest to the point that it could not justify anything; it also would depart from the common understanding of the words corruption and quid pro quo. When an official has deliberately used public dollars to return private favors, those words seem to fit. If, after attending a religious revival, a legislator were to confess to supporting widget subsidies simply to please major

296558 U.S. at 357.

297 See NAACP v. Button, 371 U.S. 415, 438 (1963) ("Broad prophylactic rules in the area of free expression are suspect.”).

298 To be sure, it sometimes is easier to prove that someone gave or accepted an unreported donation or a donation above the limit than to establish that he gave or accepted this payment as a bribe. Both the enforcement of campaign finance regulations and the enforcement of bribery laws, however, typically require proof of what happened between consenting parties in private, and when officials can prove what happened between consenting parties in private, they might as well enforce the law against bribery. 
contributors to his campaign, just about everyone would conclude that he had confessed to corruption and to giving a quid for a quo. Only a few people might dissent—all of them justices of the Supreme Court.

Perhaps, however, there would be no dissenters. Despite the contrary indications discussed above, conscious favoritism may be "in."

\section{a. The Significance of Buckley v. Valeo}

A central theme of Citizens United was "back to basics and to Buckley." The Supreme Court emphasized in particular that it drew its concept of corruption from Buckley. "When Buckley identified a sufficiently important governmental interest in preventing corruption or the appearance of corruption, that interest was limited to quid pro quo corruption,"299 it wrote. One should not interpret Citizens United in a way that would overrule Buckley rather than follow it. And Buckley clearly regarded conscious favoritism as the kind of corruption that can justify campaign finance regulation. ${ }^{300}$

Immediately after declaring that preventing corruption provided a sufficient justification for limiting campaign contributions, Buckley wrote, "To the extent that large contributions are given to secure political quid pro quo's from current and potential office holders, the integrity of our system of representative democracy is undermined." 301 The Court used the words quid pro quo four more times in its opinion. ${ }^{302}$ Someone who noticed those words and nothing else might assume that the words meant in Buckley what they mean today in a different legal context.

Today, when the Supreme Court uses the words quid pro quo in a bribery case, it refers to an actual or contemplated agreement: "[F]or bribery there must be a quid pro quo-a specific intent to give or receive something of value in exchange for an official act." ${ }^{303}$ Buckley's use of these words, however, came fifteen years before the Court first used them in a bribery case. ${ }^{304}$ At the time Buckley was decided, its language did not track the definition of a crime, and the Court clearly used the term quid pro quo differently from the way it now uses this term in bribery cases.

Buckley in fact rejected the argument that "contribution limitations

${ }^{299}$ Citizens United, 558 U.S. at 909.

${ }^{300}$ One could in fact make a plausible case that Buckley regarded even preferential access as “in.”

${ }^{301}$ Buckley, 424 U.S. at 26-27.

${ }^{302}$ Id. at 27 (twice), 45, 47.

303 Sun-Diamond Growers v. United States, 526 U.S. 398, 405-06 (1999) (emphasis in the original).

${ }^{304}$ See McCormick v. United States, 500 U.S. 257 (1991). 
must be invalidated because bribery laws and narrowly drawn disclosure requirements constitute a less restrictive means of dealing with 'proven and suspected quid pro quo arrangements."”305 The Court explained, "[L]aws making criminal the giving and taking of bribes deal with only the most blatant and specific attempts of those with money to influence governmental action.”306 In the Court's view, campaign-contribution limits were appropriate, not because they prevented bribery that might be difficult to prove, but because they blocked influences less "blatant and specific" than bribes. The evil addressed by Congress was the "attempt[] of those with money to influence governmental action" by subtle as well as blatant means. The Court spoke repeatedly of "undue influence,"307 “improper influence," 308 and "post-election special favors." 309

Buckley pointed to three illustrations of what it regarded as quid pro quo corruption, and these illustrations consisted of favoritism, not bribery. Immediately after noting that "our system of representative democracy" can be undermined by large contributions "given to secure political quid pro quo's," the Court observed, "Although the scope of such pernicious practices can never be reliably ascertained, the deeply disturbing examples surfacing after the 1972 election demonstrate that the problem is not an illusory one." 310 It then cited the D.C. Circuit's recitation of these examples in its own Buckley v. Valeo opinion. ${ }^{311}$

The first of the practices described by the D.C. Circuit - the ones the Supreme Court called "deeply disturbing" and "pernicious"-was "the revelation [of] extensive contributions by dairy organizations to Nixon fund raisers, in order to gain a meeting with White House officials on price supports." 312 Following this meeting, President Nixon approved higher price supports for milk producers, and the D.C. Circuit commented, "It is not material, for present purposes, to review . . . the controverted issue of whether the President's decision was in fact, or was represented to be, conditioned upon or 'linked' to, the reaffirmation of [a

${ }^{305}$ Buckley, 424 U.S. at 27.

${ }^{306}$ Id. at 27-28.

${ }^{307}$ Buckley, 424 U.S. at 53, 70, 76.

${ }^{308}$ Id. at 29, 30, 45, 58, 96.

${ }^{309}$ Id. at 67.

${ }^{310} \mathrm{Id}$. at 27.

${ }^{311}$ Id. at 27 n.28 (citing Buckley v. Valeo, 519 F.2d 821, 839-40 \& nn. 36-38 (D.C. Cir. 1975)). Surprisingly, Citizens United cited the same material to support its claim that "[t]he practices Buckley noted would be covered by bribery laws if a quid pro quo arrangement were proved." Citizens United, 558 U.S. at 356-57 (citing Buckley, 424 U.S. at 27 \& n.28 (citing Buckley v. Valeo, 519 F.2d 821, 839-40 (D.C. Cir. 1975))). This material in fact constituted the only support Citizens United offered.

312519 F.2d at 839 n.36. 
\$2 million campaign] pledge." 313 If favoritism did not constitute quid pro quo corruption, however, and if only bribery counted, the resolution of this issue would have mattered.

The court's second illustration consisted of "lavish contributions by groups or individuals with special interests to legislators from both parties, e.g., . . . by H. Ross Perot, whose company supplies data processing for Medicare and Medicaid programs, to members of the House Ways and Means and Senate Finance Committees ...." ${ }^{314}$ Large contributions to incumbents of both parties by people affected by their decisions strongly suggest that the contributors hope to curry favor rather than persuade the public. People who do no more than contribute to incumbents of both parties in order to gain favor, however, are not guilty of bribery.

The court's final illustration was the appointment of campaign contributors as ambassadors. Referring to a Senate committee report, the D.C. Circuit said, "As for ambassadorships, while the appointment of large contributors is not novel, the Committee's Report exposed scale and volume, and the widespread understanding that such contributions were a means of obtaining the recognition needed to be actively considered." 315 Again, a practice that "deeply disturbed" the Buckley Court and that it cited to show the existence of "political quid pro quo's" was favoritism, not bribery.

\section{b. Decisions Following Buckley}

In 1985, in FEC v. National Conservative Political Action Committee, ${ }^{316}$ the Supreme Court used the words quid pro quo again: "The hallmark of corruption is the financial quid pro quo: dollars for political favors." ${ }^{317}$ SpeechNow read this sentence as a statement that the legitimate goals of campaign finance regulation did not include reducing undue influence. ${ }^{318}$ Like Buckley, however, National Conservative Political Action Committee preceded by several years the earliest of the Supreme Court decisions articulating the quid pro quo requirement in bribery cases, and the sentences immediately preceding the "hallmark" statement sounded a lot like Aristotle: "Corruption is a subversion of the

${ }^{313}$ Buckley, 519 F.2d at 839 n.36.

${ }^{314}$ Id. at 839 n.37.

${ }^{315}$ Buckley, 519 F.2d at 839 n.38. See Final Report of the Select Committee on Presidential Campaign Activities, 93d Cong., 2d Sess., at 492-510 (1974).

316470 U.S. 480 (1985).

${ }^{317} I d$. at 497.

${ }^{318}$ See SpeechNow, 599 F.3d at 694. 
political process. Elected officials are influenced to act contrary to their obligations of office by the prospect of financial gain to themselves or infusions of money into their campaigns." ${ }^{319}$ These sentences indicated that reducing undue influence was "in."

Supreme Court decisions following National Conservative Political Action Committee, moreover, were entirely unambiguous. In 2000, in Nixon v. Shrink Mo. Gov't PAC, ${ }^{320}$ the Court wrote that its concern was "not confined to bribery of public officials, but extend[ed] to the broader threat from politicians too compliant with the wishes of large contributors." ${ }^{321}$ One year later, the Court declared in FEC v. Colorado Republican Fed. Campaign Comm. ${ }^{322}$ that corruption must be "understood not only as quid pro quo agreements, but also as undue influence on an officeholder's judgment." ${ }^{323}$ And in 2003, in a passage of McConnell v. FEC ${ }^{324}$ that Citizens United did not repudiate, the Court wrote, “Congress' legitimate interest extends beyond preventing simple cash-for-votes corruption to curbing 'undue influence.'”325 The Court noted that it was "not only plausible, but likely, that candidates would feel grateful for . . . donations and that donors would seek to exploit that gratitude." ${ }^{326}$ If Citizens United overruled any of these decisions, it did so sub silento.

\section{c. McCutcheon}

The McCutcheon plurality, which included all but one of the members of the Citizens United majority, offered this explanation of why Buckley had upheld base contribution limits: "The propriety of large contributions to individual candidates turned on the subjective intent of donors, and the Court concluded that there was no way to tell which donors sought improper influence over legislators' actions.”327

McCutcheon reaffirmed that the intent to obtain improper influence was the kind of corruption that, according to Buckley, could justify a limitation of speech. Because there was no practical way to determine

${ }^{319}$ National Conservative Political Action Committee, 400 U.S. at 497.

320528 U.S. 377 (2000).

${ }^{321}$ Id. at 389. The Court added, "[T] large contributions will work actual corruption of our political system.” Id. at 395.

322533 U.S. 431 (2000).

${ }^{323}$ Id. at 441 (2001).

324540 U.S. 93 (2003).

${ }^{325}$ Id. at 150 (quoting Colorado Republican Fed. Campaign Comm., 533 U.S. at 441).

${ }^{326}$ Id. at 145.

${ }^{327}$ McCutcheon, 134 S. Ct. at 1447. 
when this intent existed, Congress could prohibit contributions large enough to pose a significant risk of this improper motivation.

A better one-sentence explanation of why contribution limits are permissible than McCutcheon's is difficult to imagine, and this explanation is flatly inconsistent with the suggestion that an explicit or implicit agreement is necessary.

The Supreme Court's conflicting signals suggest that Citizens United might not have focused clearly on the issue and that, despite some statements that seem to exclude conscious favoritism from the realm of quid pro quo corruption, the issue at least remains open.

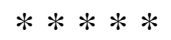

Upholding campaign finance regulations for a questionable reasonbecause they are believed to reduce bribery-could make immaterial the Supreme Court's rejection of a better reason-because they reduce conscious favoritism. If the regulations remained in place, they could serve the appropriate purpose as well as the dubious one. Recognizing that deliberately using public dollars to repay private favors is corrupt, however, would make clear that large super PAC contributions are corrupting. ${ }^{328}$

328 The Supreme Court has suggested that super PAC expenditures cannot be bribes-something that might imply, at least to the D.C. Circuit, that contributions to super PACs also cannot be bribes. One year after Citizens United, in Arizona Free Enterprise Club's Freedom Club PAC v. Bennett, 131 S. Ct. 2806 (2011), the Court declared, "The separation between candidates and independent expenditure groups negates the possibility that independent expenditures will result in the sort of quid pro quo corruption with which our case law is concerned.” Id. at 2826-27. Much more modestly, Buckley v. Valeo had said, "The absence of prearrangement and coordination of an expenditure with the candidate or his agent . . . alleviates the danger that expenditures will be given as a quid pro quo for improper commitments from the candidate.” Buckley, 424 U.S. at 4. Even Buckley's humbler observation, however, makes little sense.

The Court's argument seemed to be that people who obey the rules forbidding prearrangement and coordination will have little opportunity to reach explicit and implicit agreements. If it is appropriate to assume that people obey campaign finance restrictions, however, why can't one also assume that they obey the law against bribery? Perhaps the Court's assumption was that, while the laws against bribery are difficult to enforce, candidates and their benefactors will obey the rules requiring the separation of candidates from independent expenditure groups for the same reason that adventurers climb mountains - because they are there. Independent expenditures cannot be bribes, for if they were bribes, they would not be independent. As Thomas Reed Powell is said to have remarked, "If you can think about something which is attached to something else without thinking about what it is attached to, then you have what is called a legal mind." See Thurman W. Arnold, Criminal Attempts: The Rise and Fall of an 


\section{Why SPEECHNOW ERRED BY STRIKING DOWN LIMITS ON CONTRIBUTIONS TO SUPER PACS}

\section{A. An Inappropriate Premise}

When the D.C. Circuit struck down the BCRA's limits on contributions to super PACs in SpeechNow.org v. FEC, ${ }^{329}$ its decision rested on the view that quid pro quo corruption included explicit and implicit agreements and nothing else. ${ }^{330}$ The court could not have claimed with a straight face that contributions to super PACs do not generate what Buckley called "post-election special favors."331

Even more clearly, SpeechNow rested on Citizens United's declaration that "independent expenditures . . . do not give rise to corruption or the appearance of corruption." 332 The court reasoned that contributions to super PACs influence public officials only when they are spent, and if, as a matter of law, the money going out does not corrupt, the money coming in cannot corrupt either. The court said that the standard of review did not matter because " "something . . . outweighs nothing every time." 333 Its analysis depended on the proposition that the government had no cognizable interest-none whatever-in limiting either expenditures by super PACs or contributions to these groups. ${ }^{334}$

Abstraction, 40 YALE L.J. 53, 58 (1930) (quoting Powell).

The rules requiring the independence of independent expenditures do not bar the people who make them from having lunch with candidates or from sitting next to them at official campaign functions. There and elsewhere they can whisper about coordinating expenditures, bribes, and, if they like, robbing banks. They also can pass thick envelopes under the table. Of course the candidates and their benefactors are rarely so criminal; there is no reason for them to be. But if bribery were the way things were done, the rules forbidding coordinated expenditures would not stop them.

In fact, a sensible bribe taker does not speak directly to a bribe giver. He uses an intermediary called a bagman. The use of this intermediary makes it difficult for the bribe giver to implicate the bribe taker, and if the bagman himself attempts to incriminate the bribe taker, the bribe taker denies everything and accuses the bagman of defrauding the bribe giver of his money. Someone soliciting funds for either an independent expenditure group or an official election campaign might be an ideal bagman.

329599 F.3d 686 (D.C. Cir. 2010).

330 See id. at 694.

331 See Buckley, 414 U.S. at 67.

${ }^{332}$ Citizens United, 558 U.S. at 357.

333 Id. at 695 (quoting Nat'l Ass'n of Retired Fed. Employees v. Horner, 879 F.2d 873, 879 (D.C. Cir. 1989)).

334 The court did not discuss Cal. Medical Ass'n v. FEC, 453 U.S. 182 (1981), in which the Supreme Court upheld a limit on contributions to a political action committee 
As an earlier section of this Article explained, the statement upon which the D.C. Circuit relied was dictum and perhaps double dictum. ${ }^{335}$ Moreover, the ease with which the Supreme Court slipped from declaring the government's regulatory interest insufficient ${ }^{336}$ to declaring this interest nonexistent suggested that the Court might not have noticed the crucial difference between its two formulations. Stopping with the Court's narrower and more appropriate statement would have precluded the D.C. Circuit's analysis in SpeechNow. ${ }^{337}$

The sense that the Supreme Court might not have recognized the import of its dictum is reinforced by the Court's failure to recognize the difference between this dictum and what Buckley had said 34 years earlier. Citizens United attributed its judgment that independent expenditures do not corrupt at all to Buckley: "This confirms Buckley's reasoning that independent expenditures do not lead to, or create the appearance of, quid pro quo corruption.”338 Buckley, however, did not say that. It merely held the anticorruption interest insufficient to support expenditure limits: "We find that the governmental interest in preventing corruption and the appearance of corruption is inadequate to justify $\S$ 608(e)(1)'s ceiling on independent expenditures." 339 “[T]he independent advocacy restricted by the provision does not presently appear to pose dangers of real or apparent corruption comparable to those identified with large campaign contributions.”340

A final indication that the Court might not have meant its dictum literally is that this statement, if taken literally, would be inconsistent with a ruling the Court had made less than a year earlier-one in which its opinion was written by Justice Kennedy, the same justice who wrote

and rejected the argument that "because the contributions here flow to a political committee, rather than to a candidate, the danger of actual or apparent corruption of the political process . . . is not present.” Id. at 195. Cal. Medical Ass'n was distinguishable from SpeechNow because the PAC in question contributed to candidates; it was not an independent expenditure group. But the argument that contributions cannot be corrupting unless they ultimately flow to the candidate himself (rather than to his mother, brother, or alter-ego super PAC) does not bear reflection. No one would contend that bribes cannot corrupt unless they ultimately reach the pocket of a public official himself. See, e.g., note supra (describing the conviction of former Alabama governor Don Siegelman).

335 See text at notes supra.

336 See Citizens United, 558 U.S. at 357 ("The anticorruption interest is not sufficient to displace the speech here in question.”).

${ }^{337}$ See text at notes supra.

${ }^{338}$ Citizens United, 558 U.S. at 360.

${ }^{339}$ Buckley, 424 U.S. at 45.

${ }^{340} \mathrm{Id}$. at 46. 
the Court's opinion in Citizens United. ${ }^{341}$ Caperton v. A. T. Massey Coal Co. ${ }^{342}$ examined the combined effect of campaign contributions, PAC contributions, and independent expenditures by the chairman and chief executive officer of the Massey Coal Company, Don Blankenship. ${ }^{343}$

After a jury returned a \$50 million verdict against Massey, Blankenship spent more than \$3 million to prevent the reelection of a justice of the state supreme court that would hear Massey's appeal. He contributed the maximum amount the law allowed to the campaign of this justice's opponent-a meager \$1000. He also contributed \$2.5 million to a PAC supporting the justice's opponent and spent another $\$ 500,000$ directly. The opponent won the election and provided the decisive vote for reversing the $\$ 50$ million verdict against Massey.

The Supreme Court held that the newly elected justice's refusal to recuse himself from Massey's appeal violated the due process clause. Justice Kennedy wrote for the Court, "We conclude that there is a serious risk of actual bias . . . when a person with a personal stake in a particular case had a significant and disproportionate influence in placing the judge on the case by raising funds . . . when the case was pending or imminent." 344 Citizens United declared Caperton irrelevant, noting that Caperton's "holding was limited to the rule that the judge must be recused, not that the litigant's political speech could be banned.”345

Caperton concluded that a particular remedy for the "risk of actual bias"-recusal—was required by the Constitution. Citizens United concluded that another remedy-restricting independent expenditureswas precluded by the Constitution. Citizens United observed correctly that these two remedies, the required one and the precluded one, differed. If Blankenship's PAC contributions and independent expenditures did "not give rise to corruption or the appearance of corruption," however, why was any remedy required?

Caperton recognized the public interest in preventing the "serious risk of actual bias" posed by Blankenship's expenditures. Does this interest differ from the public interest in preventing "the appearance of corruption"? Is it less weighty? Is this interest neither sufficiently

341 Justice Kennedy was in fact the only justice to join both five-to-four decisions.

342556 U.S. 868 (2009).

343 The Court lumped all of Blankenship's electoral efforts together and repeatedly called them “contributions.” See, e.g., id. at 873 (referring to “Blankenship’s \$3 million in contributions”) \& 885 ("Blankenship’s campaign contributions . . . had a significant and disproportionate effect on the election's outcome.”). By disregarding the distinction between contributions and expenditures drawn by Buckley and other campaign finance decisions, the Court made this distinction seem insubstantial.

${ }^{344}$ Id. at 884.

${ }^{345}$ Citizens United, 558 U.S. at 360. 
“compelling” to justify a restriction of high-value speech nor sufficiently "important” to justify a restriction of low-value speech?

Caperton holds that the public interest in limiting the effect of independent electoral expenditures on the decisions of public officials exists. Because this interest is more than "nothing," "something” does not automatically trump it. A near army of commentators have concluded that Massey's holding is inconsistent with Citizens United's dictum that "independent expenditures . . . do not give rise to corruption or the appearance of corruption." 346

Speculating that the Supreme Court might not have meant this declaration quite the way it sounds does not flatter the Court, but the alternative hypothesis would be worse. Citizens United's move from a declaration of inadequacy to a declaration of non-existence might have been carefully calculated - an effort by a five-justice majority to resolve issues not presented by the case before the Court while the votes to resolve them the majority's way were at hand. On this hypothesis, lower courts would have had even less reason to regard the Court's dictum as controlling.

\section{B. A Better Starting Place}

The D.C. Circuit should have emphasized a different statement of the Citizens United opinion: "[C]ontribution limits, . . . unlike limits on independent expenditure, have been an accepted means of preventing quid pro quo corruption.”347 It should have focused on Buckley's holding that limits on contributions to official election campaigns are permissible and should have asked whether limits on contributions to super PACs could reasonably be treated differently. That question would have been easy to answer.

346 Citizens United, 558 U.S. at 357. See, e.g., Briffault, supra note , at 659-60; Richard L. Hasen, Citizens United and the Illusion of Coherence, 109 MicH. L. REV. 581, 584 (2011); Michael S. Kang, The End of Campaign Finance Law, 98 VA. L. REV. 1, 45-47 (2012); James Sample, Democracy at the Corner of First and Fourteenth: Judicial Campaign Spending and Equality, 66 N.Y.U. ANN. SuRV. AM. L. 727, 729-30 (2011); Alexander Polikoff, So How Did We Get into This Mess? Observations on the Legitimacy of Citizens United, 105 Nw. U. L. REV. COLlOQUY 203, 221-22 (2011); Adam Liptak, Foreword: Funding Justice, 52 ARIZ. L. REV. 203, 203 (2010); Anthony Johnstone, A Madisonian Case for Disclosure, 13 GEO. MASON L. REV. 413, 437-38 (2012); Larry Howell, Once Upon a Time in the West: Citizens United, Caperton, and the War of the Copper Kings, 73 MonT. L. REV. 25, 54-57 (2012); Burt Neuborne, Felix Frankfurter's Revenge: An Accidental Democracy Built by Judges, 2011 N.Y.U. REV. L. \& SoC. CHANGE 602, 659-60 (2011); Justin Levitt, Confronting the Impact of Citizens United, 29 YALE L. \& POL’Y REV. 217, 230 (2010).

${ }^{347}$ Citizens United, 558 U.S. at 359. 
Buckley offered five reasons for upholding contribution limits while striking down expenditure limits. Three of them suggested that campaign contributions have less communicative value than expenditures. The other two suggested that contributions are more corrupting.

The reasons the Supreme Court gave for treating contributions to official election campaigns as low-value speech all apply equally to super PAC contributions.

First, the Court declared that a campaign contribution "serves as a general expression of support for the candidate and his views, but does not communicate the underlying basis for the support." ${ }^{348}$ Equally, a check written to a super PAC does not convey the underlying basis for the check-writer's support.

Second, the Court noted, "The transformation of contributions into political debate involves speech by someone other than the contributor." 349 Transforming a check to a super PAC into political debate also "involves speech by someone other than the contributor."

Third, the Court said that limiting the amount of an individual's contribution "permits the symbolic support evidenced by the contribution but does not in any way infringe the contributor's freedom to discuss candidates and issues." 350 Contributors might be surprised to learn that writing a check for the maximum permissible amount to a political campaign - a check for thousands of dollars - is merely "symbolic support." ${ }^{351}$ If it is, however, so is writing a check for the same amount to a super PAC. Moreover, restricting super PAC contributions leaves a contributor free to communicate his views of candidates and issues in other ways - for example, by making truly "independent" expenditures to advocate the candidate's election. ${ }^{352}$

Super PAC contributions have no greater communicative value than campaign contributions. In addition, one of the two reasons Buckley offered for viewing independent expenditures as less corrupting than

${ }^{348}$ Buckley, 424 U.S. at 21.

${ }^{349} \mathrm{Id}$.

${ }^{350} \mathrm{Id}$

351 The Court's characterization of campaign contributions as symbolic speech was unfortunate. It wrote, "[T]he quantity of the communication by the contributor does not increase perceptibly with the size of his contribution, since the expression rests solely on the undifferentiated symbolic act of contributing." Buckley, 424 U.S. at 21. Contributions deserve some First Amendment protection, however, not because check writing is a symbolic gesture, but because these contributions make political speech possible. The larger the contributions, the more speech (as well as the more illegitimate clout) they generate.

352 This Article discusses what it takes to make an expenditure independent in text at notes supra. 
campaign contributions does not apply to super PAC contributions. The Court said, "The absence of prearrangement and coordination of an expenditure with the candidate or his agent . . . alleviates the danger that expenditures will be given as a quid pro quo for improper commitments from the candidate.”353

The rules forbidding the coordination of expenditures do not prevent a candidate from discussing anything at all with a contributor to a super PAC (although the contributor may not then act as an "agent" of the candidate by conveying talk of expenditures to those who will determine how the super PAC's funds are spent ${ }^{354}$ ). When the candidate and the donor wish to speak improperly about how large a super PAC contribution will guarantee the donor's appointment as ambassador to Belize, the rules against coordinating campaign expenditures do nothing whatever to stop them. ${ }^{355}$

Buckley's second reason for viewing independent expenditures as less corrupting than campaign contributions was that independent expenditures are of less value to a candidate. Experience in the years since Buckley has called this empirical judgment into question, but it remains endorsed by the Supreme Court. ${ }^{356}$ Unlike any of the Court's

${ }^{353}$ Buckley, 424 U.S. at 47.

354 See 11 CFR $\S \S$ 109.20(a) \& 109.21(a) (2013), available at

http://www.ecfr.gov/cgi-

bin/retrieveECFR?gp=\&SID=3e2b27155456b235682448fe6f3816df\&n=11y1.0.1.1.17. 3\&r=SUBPART\&ty=HTML.

${ }^{355}$ I have suggested that the laws forbidding prearrangement and coordination do not alleviate the danger of bribery in any situation. See note supra. But I have a power not granted to the D.C. Circuit-the power to declare that Buckley's analysis makes no sense. The discussion at this point in text does not question Buckley's analysis. Like Buckley, it assumes that everyone will obey election laws simply because they are there. Even on this assumption - that is, even on the assumption that the laws forbidding prearrangement and coordination will be fully observed-these laws do nothing to prevent or inhibit quid pro quo bargains between candidates and super PAC donors.

356 Buckley's judgment that independent expenditures are of less value to a candidate was tentative. The Court observed, "Unlike contributions, . . . independent expenditures may well provide little assistance to the candidate's campaign and indeed may prove counterproductive.” 424 U.S. at 47. Note the Court's use of the word may. The Court also said, “[I]ndependent advocacy . . . does not presently appear to pose any dangers of real or apparent corruption comparable to those identified with large campaign contributions.” Id. at 46. Note the words does not presently appear.

Post-Buckley experience suggests that the Court's provisional judgment was erroneous and perhaps backwards. With other things equal, a candidate might prefer to control expenditures himself, but there is a strong advantage to having messages sent on one's behalf for which one need take no responsibility. See text at notes supra. One lobbyist has testified, “[A]n effective advertising campaign may have far more effect on a member [of Congress] than a direct campaign contribution,” see McConnell v. FEC, 251 F. Supp. 2d 176, 556 (D.D.C. 2003) (separate opinion of Kollar-Kotelly, J.) 
other reasons for privileging expenditures over contributions, this reason may apply to contributions to super PACs. Super PAC contributions, too, may have lesser value to a candidate.

Because campaign contributions and super PAC contributions can be distinguished on this ground, Buckley's holding that Congress may limit campaign contributions did not control the decision in SpeechNow. The judgment that remained, however, would not have been difficult.

A candidate might value a $\$ 3000$ contribution to a super PAC less than a $\$ 3000$ contribution to his campaign, but he would not value a $\$ 10$ million contribution to an “alter ego" super PAC less than a \$3000 contribution to his campaign. In McCutcheon, after reiterating that " $\mathrm{t}] \mathrm{he}$ absence of prearrangement and coordination of an expenditure with the candidate or his agent . . . undermines the value of the expenditure to the candidate," the plurality acknowledged, "But probably not by 95 percent." ${ }^{357}$ A $\$ 10$ million super PAC contribution produces in spades whatever corruption or appearance of corruption a \$3000 campaign contribution can produce. If Congress may prohibit the campaign contribution (as it may and has), it should be allowed to prohibit the super PAC contribution as well. If Buckley still stands (and Citizens United says it does), SpeechNow was wrongly decided.

\section{Super PACs AND AgGregate Contribution Limits}

Citizens United allowed large business organizations to use funds from their general treasuries to support the election of favored candidates, but the business organizations did not do it. SpeechNow permitted individuals to make five-, six-, seven-, and eight-figure contributions to super PACs, and the individuals did. More than Citizens United, SpeechNow transformed American politics. It did so by drawing an implication from a dictum in the Citizens United opinion, and it made no effort to reconcile its ruling with the decision on which Citizens

(reciting "the uncontroverted testimony of lobbyist Wright Andrews"), and a former senator has noted, "Politicians especially love when a negative 'issue ad' airs against their opponent." Id. (reciting the testimony of former senator Dale Bumpers).

Citizens United did not consider what lessons America's experience since Buckley might have taught. Instead, it swept aside Buckley's qualifications and hesitancy with the declaration, "[I]ndependent expenditures . . . do not give rise to corruption or the appearance of corruption.” Citizens United, 558 U.S. at 357. As explained above, this statement was dictum, but the Court's reaffirmation of Buckley's judgment that independent expenditures are insufficiently corrupting to warrant any limitation was arguably holding. The D.C. Circuit could not properly have undertaken a reassessment of the provisional empirical judgment Buckley had made 34 years before.

${ }^{357}$ McCutcheon, 134 S. Ct. at 1454. 
United purported to rely.

If the Supreme Court were to reach a different conclusion from the D.C. Circuit's conclusion in SpeechNow, its decision might not restore the situation that existed prior to that decision. The Supreme Court's intervening decision in McCutcheon v. FEC ${ }^{358}$ might have changed the landscape.

In 2012, as noted above, Sheldon and Miriam Adelson gave \$30 million to Restore Our Future, a super PAC supporting Mitt Romney’s presidential campaign. ${ }^{359}$ If the Supreme Court were to reject SpeechNow and uphold the BCRA's limits on contributions to super PACs, the amount an individual could give to a group like Restore Our Future in a single year would be considerably less - $\$ 5000$. $^{360}$

A candidate's supporters, however, could create an unlimited number of super PACs, and a donor could give $\$ 5000$ to each of these PACs. Moreover, although a super PAC may not coordinate its expenditures with those of a candidate, it may coordinate its expenditures with those of other super PACs. ${ }^{361}$ The many super PACs supporting one candidate might all have the same manager.

Even if multiplying PACs could provide a lawful way for a contributor to donate $\$ 30$ million to support a single candidate, repudiating SpeechNow might not be an empty gesture. Enabling someone to contribute $\$ 30$ million in $\$ 5000$ portions would require the creation of 6000 super PACs, something that probably would not happen. Moreover, the risk of developing carpal tunnel syndrome could deter a contributor from writing 6000 checks. ${ }^{362}$

Still, multiplying super PACs to receive the contributions that a single super PAC could not receive looks like an easy way of circumventing the $\$ 5000$ base contribution limit. The regime of campaign finance regulation proposed by this Article would address this difficulty by allowing an individual to contribute as much as he liked to as many PACs as he liked while requiring him to take steps to ensure that no more of his funds were used to influence a single election than the law allowed. ${ }^{363}$

The BCRA addressed the multi-PAC circumvention strategy in a

358134 S. Ct. 1434 (2014).

359 See OpenSecrets.org, Politicians and Elections: Restore Our Future, http://www.opensecrets.org/pacs/pacgave2.php?cmte $=$ c00490045\&cycle=2012.

${ }^{360}$ See 2 U.S.C. $\S 441 \mathrm{a}(\mathrm{a})(1)(\mathrm{C})$.

361 See Jeremy W. Peters, Conservative "Super PACs" Synchronize Their Messages, N.Y. TIMES, Sept. 25, 2012, at A10.

362 See Donors Unchained, ThE DAILy SHOw WITH Jon STEWART, April 3, 2014, at http://thedailyshow.cc.com/videos/74yxyf/donors-unchained.

${ }^{363}$ See text at notes supra. 
different way by establishing aggregate contribution limits. An individual could contribute no more than $\$ 48,600$ to all PACs during a two-year election cycle. $^{364}$

The BCRA's aggregate limit on contribution to PACs was distinct from its aggregate limits on contributions to candidates and national political parties. A court could uphold this limit while striking down the statute's other aggregate limits. In other words, a court could strike down the provision that prevents an individual from contributing the maximum amount to as many candidates as he likes while upholding the provision that prevents an individual from giving $\$ 5000$ to each of 6000 alter ego super PACs all supporting the same candidate.

The creation of multiple super PACs was not among the circumvention strategies the Supreme Court considered in McCutcheon. SpeechNow was unchallenged, and when an individual could donate \$30 million to a single group, cloning PACs would have been pointless. Rejecting SpeechNow and upholding the BCRA's base limit on PAC contributions, however, would bring the multi-PAC circumvention strategy to the forefront.

The Supreme Court called the circumvention strategies it considered in McCutcheon "implausible" 365 and "divorced from reality." 366 There is nothing at all implausible, however, about the prospect of cloning multiple PACs to enable donors to evade the limit on contributions to a single PAC. If the BCRA's base limit on PAC contributions were upheld and the statute's aggregate limit struck down, cloning would happen.

An aggregate contribution limit probably is not the least restrictive way of blocking the multi-PAC circumvention strategy. This Article has proposed a less restrictive way. The tracking and accounting requirements proposed by this Article would be burdensome, however, and a critic could plausibly maintain that the proposed tracking would not be feasible at all.

McCutcheon was a fact-specific decision premised on the assumption that measures truly necessary to prevent the circumvention of valid base contribution limits are constitutional. If the Supreme Court were to uphold the BCRA's base limit on PAC contributions, the statute's aggregate limit might be judged necessary to prevent circumvention. McCutcheon did not resolve this issue.

\section{STORY TIME: OtTO’s FRIENDS EXERCISE THEIR RIGHTS}

${ }^{364}$ See 2 U.S.C. § 441a(a)(3); 78 Fed. Reg. 8530 (FEC Notice 2013-03) (inflationadjusted limits for the 2013-2014 election cycle).

${ }^{365}$ McCutcheon, 134 S. Ct. at 1453.

${ }^{366}$ Id. at 1456. 
This section presents a hypothetical case to show where the reasoning of SpeechNow might lead.

Being a state legislator is a full-time job in only eleven states, ${ }^{367}$ and the hypothetical state of Kenduckety is not among them. Otto, the President of the Kenduckety Senate, receives a small salary from the state, but he obtains most of his income from a used car dealership he owns and manages, Otto's Autos.

Kenduckety recently enacted a tough code of government ethics. Under this code, Libby, a registered lobbyist, may not buy an automobile from Otto's and may not hire Otto's wife as her real estate agent. In fact, she may not buy Otto a hamburger.

One day, however, as Otto read the Kenduckety Clarion, he discovered an advertisement for Otto's Autos he had not placed. This advertisement not only praised Otto's Autos but called the owner of a rival dealership a deadbeat dad. A note at the bottom of the advertisement revealed that Libby had approved its message and purchased it. A delighted Otto telephoned Libby and expressed his gratitude.

Other people who were or wished to be friends of the President of the Kenduckety Senate followed Libby's lead. Within weeks, countless billboards, direct mailings, and radio and television advertisements urged the public to buy autos from Otto's and to loathe its competitors.

A few weeks after the barrage began, Otto's advertising manager resigned to form a PAC. This PAC was not a "political action committee." It was a "placement of advertising committee." A more conventional super PAC organized by one of Otto's former campaign managers already supported his political efforts.

The mission of the new PAC, Kenduckians Drive Forward, was to ensure that advertising purchased by the friends of Otto's Autos would be distributed among appropriate media outlets and would remain on point and effective. With the establishment of this PAC, Libby made a large contribution and stopped placing advertisements on her own.

Libby was confident that both her independent expenditures on behalf of Otto's Autos and her contributions to the new PAC were constitutionally protected. Unlike the lunches at McDonald's she could no longer buy Otto, these expenditures and contributions were speech.

Libby in fact consulted a lawyer. At their first meeting, he cautioned Libby that she had engaged in commercial rather than political speech and that commercial speech usually is less protected.

Libby then cast some of her favors in the form of political speech.

\footnotetext{
367 See Margaret Robertson Ferguson, The Executive Branch of State GovernMENT: PEOPLE, PRoCESS, AND POLITICS 191 (2006).
} 
Under Kenduckety's new Code of Government Ethics, she could no longer give bottles of Scotch and fruit baskets as birthday presents to elected officials. She concluded, however, that the code could not block her from retaining high-priced political satirists to appear at their birthday parties. In accordance with a contract Libby then negotiated with Bill Maher's agent, Maher knocked at the doors of progressive officials while their birthday parties were in progress and offered to deliver a monologue. Dennis Miller knocked at the doors of conservatives. Libby's birthday gifts were a hit with everyone. ${ }^{368}$

When Libby met her lawyer again, the lawyer reported that he had done some research. Commercial speech was indeed judged by a different standard than political speech, but in the lawyer's view, even Libby's commercial speech on behalf of Otto's Autos was constitutionally protected.

The lawyer explained that a limitation of commercial speech must advance a "substantial" governmental interest and be no more extensive than necessary to advance this interest. ${ }^{369}$ Similarly, he said, a limit on political contributions must be "“closely drawn' to match a 'sufficiently important interest." 370 Unlike political speech, which is fully protected, both commercial speech and political contributions land one tier down. Because the D.C. Circuit held in SpeechNow that super PAC contributions were protected, the lawyer concluded that Libby's independent expenditures on behalf of Otto's Autos must be protected as well.

The lawyer was somewhat more troubled by Libby's contributions to Kenduckians Drive Forward. These contributions were doubly devalued because they were (1) commercial rather than political and (2) contributions rather than independent expenditures. The lawyer suggested that these contributions might land, not one, but two tiers down. ${ }^{371} \mathrm{He}$ noted, however, that when no interest at all supports a restriction of speech, the standard of review does not matter. If super PAC contributions do not create even the appearance of quid pro quo corruption, neither do Libby's, and quid pro quo corruption is the only kind that counts.

The analysis that led Libby's lawyer to conclude that Libby's PAC

368 Libby kept her birthday presents a surprise and never coordinated her expenditures with anyone.

369 See, e.g., Central Hudson Gas \& Elec. Corp. v. Public Serv. Comm’n, 447 U.S. 557, 566 (1980); Thompson v. W. States Med. Ctr., 535 U.S. 357, 366-67 (2002).

370 See Nixon v. Shrink Mo. Gov’t Pac, 528 U.S. 377, 387-88 (2000); FEC v. Beaumont, 539 U.S. 146, 158-59 (2003).

${ }^{371}$ Before they land, the Supreme Court must construct the tier. Perhaps the Court should insist that legislative restrictions of twice devalued speech must advance a "sort of” important interest in a "pretty good” way. 
contributions were constitutionally protected matched the analysis that led the D.C. Circuit to protect super PAC contributions. The lawyer began with Citizens United's dictum, “[W]e now conclude that independent expenditures . . . do not give rise to corruption or the appearance of corruption" 372 and then concluded that because a PAC's expenditure of contributed funds does not corrupt, the contributions themselves cannot corrupt. In light of Citizens United's "holding as a matter of law that independent expenditures do not corrupt or create the appearance of quid pro quo corruption," 373 the government simply had "no anti-corruption interest” in limiting Libby's contributions. ${ }^{374}$ According to Libby's logical lawyer, the "task of weighing the First Amendment interests implicated by contributions . . . against the government's interest in limiting such contributions" is therefore easy. ${ }^{375}$ “'[S]omething . . . outweighs nothing every time."”376

The analysis of Libby's lawyer was careful and compelling, but something seems wrong with it. Gifts intended to corrupt public officials should not become constitutionally protected simply because they also finance speech to the public.

\section{CONCLUSION}

This Article has considered what can be said for and against a bumper sticker's declarations that money is not speech and that corporations are not people. It has proposed a framework for evaluating the constitutionality of campaign-finance regulations that differs from the one currently employed by the Supreme Court. And it has proposed a legislative scheme of campaign-finance regulation that would effectively limit contributions while respecting the Supreme Court's campaign finance decisions.

Mostly, however, this Article has focused on an issue the Supreme Court has not addressed-the validity of limiting contributions to super PACs. Prior to Citizens United v. FEC, ${ }^{377}$ the FEC enforced a statute that limited a person's contributions to one of these groups to $\$ 5000$ per year, and Citizens United did not consider the validity of this statute. Emphasizing that the issue before it was one of expenditure limits, not

${ }^{372}$ Citizens United, 558 U.S. at 357.

${ }^{373}$ SpeechNow.org. v. FEC, 599 F.3d 686, 694 (D.C. Cir. 2010).

${ }^{374}$ Id. at 695.

${ }^{375} \mathrm{Id}$.

${ }^{376}$ Id. (quoting Nat'l Ass'n of Retired Fed. Employees v. Horner, 879 F.2d 873, 879 (D.C. Cir. 1989)).

377558 U.S. 310 (2010). 
contribution limits, the Court struck down a prohibition of independent political expenditures by labor unions and corporations.

Contrary to widespread perception, the ruling in Citizens United did not lead to the domination of American politics by large business organizations. During the 2012 campaign, not one Fortune 500 company exercised the right that Citizens United had recognized to make independent electoral expenditures.

In SpeechNow.org v. FEC, ${ }^{378}$ the en banc D.C. Circuit unanimously held Congress's limit on donations to super PACs unconstitutional. The court said that one sentence in the Citizens United opinion compelled its result. Citizens United had said that independent expenditures do not corrupt, and the court reasoned that if independent expenditures do not corrupt, the contributions that make these expenditures possible cannot corrupt either. Several other courts of appeals made the same judgment.

The SpeechNow ruling led to the proliferation of super PACs. As a result of the D.C. Circuit's decision, these "attack dogs" could accept vastly larger contributions than the candidates' own campaign organizations could accept. According to the D.C. Circuit (or the Supreme Court or the two courts together), the First Amendment required this bizarre result.

Again, large business corporations were generally uninterested in exercising the recently recognized right. Four hundred ninety of the Fortune 500 companies made no super PAC contributions in 2012, and only one contributed more than $\$ 1$ million. Wealthy individuals, however, noted the disappearance of the $\$ 5000$ limit, and 95 individuals or couples contributed \$1 million or more to super PACs in 2012. ${ }^{379}$

As this Article has shown, the pronouncement on which the D.C. Circuit rested its decision was dictum, and the Supreme Court offered several indications that it did not mean this declaration quite the way it sounds. Moreover, SpeechNow rested on a narrow view of corruptionone declaring in effect that the use of public dollars to repay private favors does not qualify as corruption unless the payoff was arranged in advance. Although some language in Citizens United seemed to support this view, the Supreme Court had endorsed a broader concept of corruption in prior decisions, and language later approved by most members of the Citizens United majority in McCutcheon was also incompatible with this view.

Starting from a different premise in SpeechNow would have produced

378599 F.3d 686 (D.C. Cir. 2010).

379 See OpenSecrets.org, 2012 Top Donors to Outside Spending Groups, http://www.opensecrets.org/outsidespending/summ.php?cycle=2012\&disp=D\&type=V \&superonly $=\mathrm{N}$. 
a different result. The D.C. Circuit should have asked whether contributions to super PACs can sensibly be treated differently from contributions to official election campaigns, and the answer to that question would have been an obvious no.

Whether Congress may limit super PAC contributions warrants the Supreme Court's attention. The SpeechNow decision has driven American government toward what Aristotle called the "perverted" or "corrupted" form in which officials neglect the common good and "rule with a view to the private interest." 380

${ }^{380}$ ARISTOTLE, Politics 59 (Benjamin Jowett, tr.) (Forgotten Books ed. 2007). 


\section{APPENDIX A}

\section{Have Citizens United And SPEECHNow Ended The Game?}

This Article ended by saying that whether Congress may limit super PAC contributions warrants the Supreme Court's attention, but a court's attention cannot be paid unless someone brings a lawsuit. This appendix considers whether, by halting the enforcement of restrictions on contributions to super PACs, Citizens United and SpeechNow have left no one with standing to raise the issue again.

Justice Holmes described holding an act of Congress unconstitutional as "the gravest and most delicate duty that this Court is called on to perform." ${ }^{381}$ Chief Justice Marshall said that a court should declare a statute unconstitutional only when "[t]he opposition between the Constitution and the law [is] such that the judge feels a clear and strong conviction of their incompatibility with each other.”382 The law usually tilts the game board against litigants who challenge a statute's constitutionality. The Supreme Court affords Congress's action a "presumption of constitutionality." 383

In one respect, however, the Supreme Court has tilted the game board in the opposite direction. No matter how many victories the defenders of a statute's constitutionality win, the law's challengers may keep playing. Once the challengers score a victory, however, the game is likely to be over. The game becomes one of sudden death but only for one side.

Rulings upholding statutes and regulations are always subject to reconsideration. A person or group subject to these regulations can challenge their enforcement and attempt to persuade a court to overrule the decisions sustaining them. Citizens United, which overruled two prior decisions, illustrates how new challengers may bring new lawsuits until victory is won.

Because hardly anyone has standing to challenge the non-enforcement of statutes and regulations, however, even a five-to-four decision halting a statute's enforcement may be invulnerable. In the years following this ruling, the composition of the Supreme Court may change, and circumstances may change too. Because no one can raise the issue again, however, the declaration of unconstitutionality may last forever. The law of standing may effectively place decisions about the constitutionality of statutes on a one-way ratchet.

${ }^{381}$ Blodgett v. Holden, 275 U.S. 142, 148 (1927) (Holmes, J., concurring).

${ }^{382}$ Fletcher v. Peck, 10 U.S (6 Cranch) 87, 128 (1810).

${ }^{383}$ E.g., O’Corman \& Young, Inc. v. Hartford Fire Ins. Co., 282 U.S. 251, 257-58 (1930). 
After the rulings in Citizens United and SpeechNow, the FEC halted enforcement of the statute limiting contributions super PACs. ${ }^{384}$ Congress's use of an administrative agency rather than the judiciary to enforce election law, however, bends the law of standing, so the ratchet may not hold.

The Supreme Court allows a litigant to challenge an agency's nonenforcement of a statute when Congress has specifically authorized this challenge and the litigant is suffering or is likely to suffer injury in fact. ${ }^{385}$ And federal election law authorizes challenges to FEC inaction. It allows anyone who believes that an election-law violation has occurred to complain to the FEC, ${ }^{386}$ and it authorizes a party "aggrieved" by the FEC's dismissal of a complaint to seek review in the courts. ${ }^{387}$ Some prospective plaintiffs probably could establish injury in fact. At least a candidate for federal office whose election was opposed by a super PAC that accepted contributions above the limits could do so.

The validity of a decision striking down a statute also could become a collateral issue in a lawsuit brought for a purpose other than challenging an agency's failure to enforce it. For example, in a lawsuit brought to challenge a campaign finance regulation that survived Citizens United, a defender of the regulation might argue that, even if Citizens United's reasoning could lead to invalidating the regulation, Citizens United should be overruled.

One cannot appropriately assume, however, that an opportunity to overrule Citizens United will inevitably arise or even that such an opportunity is likely to arise. Nor can one appropriately assume that the Supreme Court, which declined to review SpeechNow, ${ }^{388}$ will have any further opportunity to consider the issue presented by that case. Even when a ruling striking down a statute does not end the game entirely, it tilts the board substantially. ${ }^{389}$

${ }^{384}$ See text at notes supra.

385 See Massachusetts v. EPA, 549 U.S. 497 (2007) (holding that the EPA's refusal to regulate greenhouse gases presented a risk of harm to Massachusetts that was “actual” and “imminent”); FEC v. Akins, 524 U.S. 11 (1998) (holding that the FEC's denial of information to which voters were entitled by statute constituted injury in fact).

386 See 2 U.S.C. $\S 437 g(a)(1)$.

387 See 2 U.S.C. $\S 437 g(a)(8)(A)$.

388 See Keating v. FEC, 131 S. Ct. 553 (2010) (denying a writ of certiorari to review SpeechNow.org v. FEC, 599 F.3d 686 (D.C. Cir. 2010)).

${ }^{389}$ Even after Citizens United and SpeechNow, several states sought to enforce their own statutory limits on super PAC contributions. The federal courts of appeals, however, sustained challenges to the states' enforcement efforts, and none of the states appear to have sought Supreme Court review. See Letter to the Hon. Mae A. D’Agostino, United States District Court for the Northern District of New York, from Brian A. Sutherland, Assistant Solicitor General of the State of New York, May 23, 
[August 27, 2014] LIMITING CONTRIBUTIONS

2014; email to the author from Jonathan Mitchell, Solicitor General of the State of Texas, Dec. 21, 2013. 


\section{APPENDIX B}

\section{The EfFEct of CAMPAign Dollars I: STATISTICAL AND NON- STATISTICAL EVIDENCE}

Citizens United declared, "[T]here is only scant evidence that independent expenditures even ingratiate." 390 If the Supreme Court meant to suggest that expenditures differ from contributions (which not only ingratiate but corrupt so much that Congress may restrict them), SpeechNow erred by declaring that contributions cannot influence candidates unless expenditures do too. Perhaps, however, the Supreme Court saw no reason to believe that either expenditures or contributions ingratiate.

In support of its claim that independent expenditures had not been shown to ingratiate, the Court cited evidence that a federal district judge had assembled to show just the opposite. The Court cited a section of the separate opinion of Judge Kollar-Kotelly in McConnell v. FEC ${ }^{391}$ headed "Federal Candidates and Political Parties Know and Appreciate Who Runs Candidate-Centered Issue Advertisements in their Races." 392 This section recited testimony from campaign consultants, a lobbyist, and former office holders, all of it resembling the testimony of former senator Dale Bumpers: "Candidates whose campaigns benefit from these ads greatly appreciate the help of these groups. In fact, Members will also be favorably disposed to those who finance these groups when they later seek access to discuss pending legislation." 393

Judge Kollar-Kotelly observed, "Plaintiffs have put forth no contrary evidence ..." She then recited testimony that "[a]n effective advertising campaign may have far more effect on a member than a direct campaign contribution," that groups "apprise politicians of the advertisements they run on their behalf," and that politicians "demonstrate their appreciation" by raising money for the groups. ${ }^{394}$ Citizens United's citation of this material for the proposition that "there is only scant evidence that independent expenditures even ingratiate" was surprising. Perhaps the Court considered the evidence "scant" simply because it consisted of the testimony of knowledgeable observers and was not "scientific" or

${ }^{390}$ Citizens United v. FEC, 558 U.S. at 310.

391251 F. Supp. 2d 176, 555-57 (D.D.C. 2003) (opinion of Kollar-Kotelly, J.).

${ }^{392} \mathrm{Id}$. at 555 . This section spoke of issue advertisements placed by groups more fettered than today's super PACs. The expenditures of today's super PACs would have as much influence or more.

${ }^{393} I d$. at 556.

${ }^{394}$ Id. 
quantitative. The misguided sense that only quantitative evidence matters has become commonplace. I have called this sense "the bottom-line, collectivist, statistical, empirical mentality.”395

Statistically-minded researchers have examined whether their methods can establish that campaign contributions influence legislators' votes, and although their findings have been mixed, ${ }^{396}$ most have answered no. ${ }^{397}$ Because nearly all of their research preceded the explosion of contributions that followed Citizens United and SpeechNow, one may question its continuing relevance. Moreover, there was little reason to give much weight to most of the researchers' conclusions even prior to SpeechNow. Their methods foundered on a problem of covariance and would have been unlikely to reveal a strong effect even if one existed.

A legislator who supports conservative measures usually is a conservative. He usually has received campaign contributions from conservative donors and been elected by conservative voters. Separating the effects of campaign contributions on his votes from the effects of his personal views and those of his constituents is difficult and may be impossible. Statistical analysis cannot determine whether the chicken came before the egg or the egg before the chicken. Nevertheless, researchers have kept trying.

Although some researchers have purported to control for legislators' "ideology," they could not do so. They could control only for the legislators' past actions-actions that themselves might have been influenced by campaign contributions. The most frequently cited of the studies concluding that campaign contributions have no provable effect on legislative votes is one that Stephen Ansolabehere, John M. de Figueiredo, and James M. Snyder, Jr. published in 2003. ${ }^{398}$ This study focused on the scores that the U.S. Chamber of Commerce gives members of Congress each year on the basis of their "key business

395 See Albert W. Alschuler, "Close Enough for Government Work": The Exclusionary Rule After Leon, 1984 S. CT. REV. 309, 346.

396 See Nixon v. Shrink Mo. Gov’t Pac, 528 U.S. 377, 395 (2000) (observing that some studies "are said to indicate that large contributions to public officials or candidates do not actually result in changes in candidates' positions," that "[o]ther studies point the other way," and that "there is little reason to doubt that sometimes large contributions will work actual corruption of our political system”).

${ }^{397}$ See Stephen Ansolabehere, John M. de Figueiredo \& James M. Snyder, Jr., Why is There so Little Money in U.S. Politics?, 17 J. ECON. PersPectives 105 (2003). Table 1 at page 113 of this study reviews the findings of 36 prior studies. "In three out of four instances, campaign contributions had no statistically significant effects on legislation or had the 'wrong' sign—suggesting that more contributions lead to less support.” Id. at 114.

${ }^{398}$ See id. 
votes." ${ }^{399}$ It reported that these scores did not vary with the size of the "business and labor" contributions members had received. 400

If notable changes in the legislators' scores had followed large changes in either business or labor contributions, one might have inferred that the contributions affected votes. The absence of any discernable change, however, provided little reason to conclude that votes were driven by conviction rather than cash.

Consider a Democrat who recognized on his first run for Congress that labor union PACs were the largest contributors to Democrats in his district. This candidate might have swallowed hard and endorsed the unions' legislative agenda despite his personal reservations. If, following his election, this member had continued to support the unions' proposals and continued to collect their cash, neither an examination of his Chamber of Commerce scores nor any other quantitative study would reveal that his votes had been driven by contributions. Union contributions might have increased in some years (for example, when the member faced a tough election) and fallen in others, but his scores would have remained the same. ${ }^{401}$ One former member of Congress

399 See U.S. Chamber of Commerce, How They Voted, http://www.uschamber.com/issues/legislators/how-they-voted.

400 Actually, when the Ansolabehere group controlled only for party affiliation and past constituent voting patterns (and when they employed a standard regression model rather than one with "legislator fixed effects"), they found that business and labor contributions did predict Chamber of Commerce scores and that this correlation was statistically significant. See Ansolabehere et al., supra note, at 116 . The authors, however, considered other statistical models more revealing.

${ }^{401}$ In some of its models, the Ansolabehere group treated "electoral competition" as an "instrumental variable." It explained, "[T]he idea is that a close race increases an incumbent's demand for PAC contributions, producing an exogenous shift in contributions via increase in the propensity to 'sell' services, including roll call votes." Ansolaehere et al., supra note , at 115. The authors' hypothesis appeared to be: If members' Chamber of Commerce scores became more pro-labor when they faced close elections and received increased contributions from union PACs, one could reasonably infer that they bent to their contributors' desires. By the same token, if their scores remained the same, one could infer that they voted their consciences (or possibly their constituents' desires).

The second inference, however, would be unwarranted. Once a member had "sold out" to labor interests, one could expect a close election to bring increased contributions from union PACs without bringing any change in his Chamber of Commerce score. The purpose and effect of the increased union contributions would have been, not to change the member's already favorable votes, but simply to enable him to retain his seat. Similarly, if a close election brought increases in both business and labor contributions, one would expect no change in a member's score.

The authors' treatment of their second "instrumental" variable was similarly confusing. They sought to assess the effect of a member's "power" by employing three variables-“a dummy variable indicating that a member is a party leader, a dummy 
acknowledged, "[I]t has got to be on your mind that a vote one way or the other is going to affect the ability to raise money." 402 No social science research has called the honesty or accuracy of this statement into question.

After finding that no effect of contributions on Chamber of Commerce scores could be proven, Ansolobehere and his coauthors concluded, "In our view, campaign contributions should not be viewed as an investment, but rather as a form of consumption . . ." "403 Interest groups, however, may seek to advance their interests in either (or both) of two ways - by promoting the election of candidates who favor their positions and/or by persuading candidates inclined to oppose their positions or on the fence to move in a beneficial direction. ${ }^{404}$ Whether the contributions do one thing or the other, contributors hope for a return on their investments and are not simply buying a yacht. No quantitative research indicates that donations by interest groups should be regarded as a form of consumption rather than a form of investment.

To be sure, the two form of investment differ. Unlike giving money to a candidate to influence him to change his position, spending money to persuade the public to support a candidate is protected by First Amendment. But both things can happen at the same time.

Some donations plainly are motivated by a desire to buy favor. Only the goal of obtaining special access and/or other favors can explain why corporate PACs "hedge" by giving to both candidates in the same race, why their contributions regularly favor the party in power, and why they

variable indicating that the member is a committee chair, and a dummy variable indicating that the member was on the Ways and Means or Energy and Commerce committee (probably the two most powerful committees with respect to business issues)." Id.

Powerful members attract more campaign contributions than others, but why they do so is unclear. Powerful members may attract large contributions because they have more "clout" than other members and their votes are especially valuable. On this hypothesis, the price of their votes should increase, and the effect of every dollar contributed should decline. An equally plausible hypothesis, however, is that powerful members attract large contributions because they can influence the decisions that precede roll call votes, including what language important bills contain. These members may receive large contributions for reasons that have little or nothing to do with changing their ultimate roll call votes.

402 See Eric Lipton, For Freshmen in the House, Seats of Plenty, NY TIMEs, Aug. 10, 2013, at A1 (reporting the statement of Brad Miller, a former Democratic representative from North Carolina).

${ }^{403} I d$. at 117.

${ }^{404}$ Political scientists speak of two models of political giving-the "ideological (or 'position-induced') model” and "the investor (or 'service induced') model." See Adam Bonica, Avenues of Influence: On the Political Expenditures of Corporations and Their Directors and Executives 4 (2013), available at http://ssrn.com/abstract=2313232. 
donate generously to powerful incumbents in safe districts. ${ }^{405}$

One may reasonably suppose, however, that the other form of investment predominates. For the most part, even corporate PACs hope to advance their interests by persuading voters to elect candidates already disposed to favor these interests. Social science research may establish that the market for votes is not a spot market and that liberals do not become conservatives overnight. ${ }^{406}$ Still, campaign contributions can change votes sometimes, and sometimes may be enough to make the contributions worthwhile even apart from their effect in persuading voters.

The Ansolobehere study notes that nearly "all research on donors' influence in legislative politics examines the effects of contributions on roll call votes cast by member of Congress." 407 Roll call votes, however, are watched not only by the Chamber of Commerce but also by other interest groups, the media, and the public. Favoritism for donors may be more likely to affect less visible and less ideologically charged decisions. ${ }^{408}$ Daniel Lowenstein has remarked that some social science researchers resemble "the fabled inebriate who searched for a lost key at

405 See id. at 16-28; Jeffrey Milyo, David Primo \& Timothy Groseclose, Corporate PAC Campaign Contributions in Perspective, 2 Business \& POLITICS 75, 76 (2000) ("[I]t is well-established that PAC contributions flow disproportionately to incumbent office holders, majority party members, members of powerful committees, and to members on committees with jurisdictions relevant to the PAC sponsor.”); Lloyd N. Cutler, Can the Parties Regulate Campaign Financing?, 486 ANNALS OF THE AM. ACADEMY OF POL. \& SoC. SCI. 115, 116 (1986) (quoting former Republican Presidential Nominee Bob Dole: "When political action committees give money, they expect something in return other than good government.”).

406 This research appears to supply a sufficient answer to the "public choice" economists who see contributors simply as buying legislators' votes. William Landes and Richard Posner describe what appears to be a common view among economists and taxi drivers:

In the economists' version of the interest-group theory of government, legislation is supplied to groups or coalitions that outbid rival seekers of favorable legislation. . . . Payments take the form of campaign contributions, votes, implicit promises of future favors, and sometimes outright bribes. In short, legislation is "sold" by the legislature and "bought" by the beneficiaries of the legislation.

William W. Landes \& Richard A. Posner, The Independent Judiciary in an Interest Group Perspective, 18 J.L. \& ECON. 875, 877 (1975).

${ }^{407}$ Ansolaehere et al., supra note, at 112.

${ }^{408}$ See Richard L. Hall \& Frank W. Wayman, Buying Time: Moneyed Interests and the Mobilization of Bias in Congressional Committees, 84 AM. POL. SCI. REV. 797 (1990) (concluding that political favors are likely to take a less visible form than roll call votes). 
night at the opposite end of the block from where he dropped it because the light was better there." 409

Party leaders, committee chairpersons, and the members of key committees are in a position to influence the important decisions that precede roll call votes. They can determine what a bill says and whether it will come to a vote at all. ${ }^{410}$ These legislators receive contributions in considerably larger amounts than other legislators, ${ }^{411}$ and no study suggests that donors are mistaken in thinking that their contributions to powerful legislators pay dividends. Returns can take the form of phone calls, phrasing, and procedure rather than altered roll call votes. ${ }^{412}$

The three appendices that follow review some non-quantitative evidence on the effects of campaign cash. As Yogi Berra explained, "You can observe a lot by just watching." 413

${ }^{409}$ Daniel Hays Lowenstein, On Campaign Finance Reform: The Root of All Evil is Deeply Rooted, 18 Hofstra L. ReV. 301, 314-15 (1989).

410 The New York Times recently noted that the House Financial Services Committee is sometimes called the "cash committee" because its members receive more donations than those of any other committee. "With so many lawmakers clamoring to be on the Financial Services Committee, it has grown to 61 members from 44 since 1980, forcing the installation of four tiered rows of seats in the Rayburn House Office Building.” Lipton, supra note .

411 See, e.g., Stephen Ansolabehere \& James M. Snyder, Jr., Money and Institutional Power, 77 TEX. L. REV. 1673, 1689-98 (1999).

${ }^{412}$ Cf. James V. Grimaldi \& Susan Schmidt, Lawmaker From Ohio Subpoenaed in Abramoff Case, WASHINGTON PosT, Nov. 5, 2005, at A4 ("As chairman of the powerful House Administration Committee, [Representative Robert] Ney promised to add language to a bill to reopen a casino for a Texas Indian Tribe that [lobbyist Jack] Abramoff represented. After Ney agreed to prepare the legislation, Abramoff directed tribal officials to make three contributions totaling \$32,000 to Ney's campaign and political action committees.”).

${ }^{413}$ See Red Foley, Surprise-Choice Yogi on Managerial Spot, in YogI BERRA: AN AMERICAN ORIGINAL 105 (New York Daily News Legends Series 1998) (reprinting a column of Nov. 10, 1963). 


\section{APPENDIX C}

\section{The EfFect of CAmpaign Dollars II: The Generosity of SHELdON ADELSON}

This Article has noted that, in 2012, Sheldon Adelson, a Las Vegas casino owner, and his wife Miriam donated \$30 million to Restore Our Future, a super PAC supporting the election of Mitt Romney as President. ${ }^{414}$ The couple apparently donated $\$ 140$ million or more to electoral efforts that year. ${ }^{415}$ Prior to their initial $\$ 10$ million contribution to Restore Our Future, Sheldon Adelson met with Romney in Las Vegas and reportedly sought "assurance that Romney would support Israel more strongly than President Obama has.”"416

Romney was not Sheldon Adelson's first choice for the 2012 Republican presidential nomination. Before contributing to the Romney campaign, he and his family donated \$21 million to support the campaign of former Speaker Newt Gingrich. ${ }^{417}$ Adelson in fact financed a multimillion-dollar campaign of negative advertisements about Romney, ${ }^{418}$ and he complained publicly that Romney waffled on the issues. ${ }^{419}$

Romney's support for Israel did not waver following the Adelsons' initial $\$ 10$ million contribution. In the month after this contribution, Romney accused President Obama of “deriding Israel's leaders” and of "shabby treatment of one of our finest friends." ${ }^{420}$ Shortly after making these remarks, he traveled to Israel where he declared that Jerusalem is Israel's capital and announced that he would move the American

414 See OpenSecrets.org, Politicians and Elections: Restore Our Future, http://www.opensecrets.org/pacs/pacgave2.php?cmte=c00490045\&cycle=2012.

415 See Theodoric Meyer, How Much Did Sheldon Adelson Really Spend on Campaign 2012?, PROPuBLICA, Dec. 20, 2012, http://www.propublica.org/article/howmuch-did-sheldon-adelson-really-spend-on-campaign-2012.

416 See Callum Borchers, Romney PAC Gets \$10M Gift: Casino Magnate May Give $\$ 100 M$ in Election, Boston GLOBE, June 14, 2012, at A10.

417 See Alicia Mundy \& Sara Murray, Adelson Gives \$10 Million to Pro-Romney Super PAC, WALL ST. J., June 13, 2012, available at http://blogs.wsj.com/washwire/2012/06/13/adelson-gives-10-million-to-pro-romneysuper-pac/.

418 See Trip Gabriel \& Nicholas Confessore, PAC Ads to Attack Romney as Predatory Capitalist, N.Y. TIMES, Jan. 9, 2012, at A1.

419 See Peter H. Stone, Sheldon Adelson Spent Far More on Campaign than Previously Known, HufFInGTON Post, Dec. 3, 2012, http://www.huffingtonpost.com/2012/12/03/sheldon-adelson-2012election_n_2223589.html.

420 Mitt Romney, Remarks at the VFW National Convention, July 24, 2012, available at http://historymusings.wordpress.com/2012/07/24/full-text-campaign-buzzjuly-24-2012-mitt-romneys-speech-on-foreign-policy-national-security. 
embassy there when the Israeli government said the time was right. ${ }^{421} \mathrm{He}$ also offered an explanation of why Israel's GDP per capita vastly exceeds the Palestinians': "Culture makes all the difference." ${ }^{422}$

Adelson was a member of the audience that stood and cheered Romney’s remarks. ${ }^{423}$ He later was seated next to Romney at a \$50,000per-couple breakfast in Jerusalem for American campaign donors. ${ }^{424}$ No one-perhaps not even Romney himself_can remember whether the chicken came before the egg at this breakfast.

A presidential candidate might bend his rhetoric on a major foreign policy issue to bring cheers and cash from large contributors, and his rhetoric might shape his policies once elected. Social science researchers could never prove it, however, and neither could anyone else.

Although Adelson's contributions seem to have been prompted primarily by his concept of the public good, ${ }^{425}$ his private interests might have played a part. For one thing, Adelson's extensive business interests abroad receive favorable tax treatment that the incumbent President he opposed had sought unsuccessfully to end. ${ }^{426}$ For another, Chinese

421 See Romney Declares Jerusalem Capital of Israel, THE PORTLAND PRESS Herald, July 30, 2012, at A3; Jodi Rudoren \& Ashley Parker, Romney Backs Israeli Position on Facing Iran, N.Y. TIMES, July 30, 2012, at A1.

422 See Text of Romney's Remarks About Culture, Israel and the Palestinians, Wash. Post, July 31, 2012, http://www.washingtonpost.com/politics/text-of-romneysremarks-about-culture-israel-and-the-palestinians/2012/07/31/gJQAjmsrNX_story.html; Ashley Parker, Romney Comments on Palestinians Draw Criticism, N.Y. Times Blogs (The Caucus), July 30, 2012, available on LEXIS.

${ }^{423} \mathrm{Id}$.

${ }^{424}$ See Thomas L. Friedman, Why Not in Vegas?, N.Y. Times, July 31, 2012, at A23; Kevin Liptak, Romney Raises More than \$1 Million in Jerusalem, CNN Wire, July 30, 2012 (available on LEXIS).

${ }^{425}$ Adelson not only criticized the Obama administration's foreign policy but also said, "What scares me is the continuation of the socialist-style economy we've been experiencing for the past four years." Steven Bertoni, Billionaire Sheldon Adelson Says He Might Give \$100M to Newt Gingrich or Other Republican, Forbes.com, Feb. 21, 2012, available at http://www.forbes.com/sites/stevenbertoni/2012/02/21/billionairesheldon-adelson-says-he-might-give-100m-to-newt-gingrich-or-other-republican/.

Adelson, however, does not oppose all forms of socialism. Although he condemns Obamacare, he favors the sort of "socialized medicine" (his term) found in Israel. See Alicia Mundy, Sheldon Adelson: "I'm Basically a Social Liberal", WALL ST. J. WASHINGTON WIRE, Dec. 5, 2012, http://blogs.wsj.com/washwire/2012/12/05/sheldonadelson-im-basically-a-social-liberal/.

${ }^{426}$ According to the New York Times, 90 percent of the earnings of Adelson's company come from hotel and casino properties in Singapore and Macau. As a result, "the company now has a United States corporate tax rate of 9.8 percent, compared with the statutory rate of 35 percent." See What Sheldon Adelson Wants, supra note . The Times did not indicate what taxes the company paid abroad but did note that the income tax rate in Macau was zero. 
currency restrictions that Governor Romney pledged to oppose were damaging Adelson's foreign interests. ${ }^{427}$ In addition, both the Securities Exchange Commission and the Department of Justice were investigating Adelson's company, the Las Vegas Sands Corporation, for violating the Foreign Corrupt Practices Act. ${ }^{428}$ The Justice Department was investigating the company for money laundering as well. ${ }^{429}$

Adelson told an interviewer that the accusations against his company were unfounded and that officials had targeted him because of his political activity. When he listed several reasons for contributing to the Romney campaign, his concern that President Obama's reelection would bring further "vilification" not only of Adelson himself but also of other Obama opponents topped the list. ${ }^{430}$

Second on the list was the fact that (in the interviewer's words) "[i]f

${ }^{427}$ On the assumption that half the patrons of Macau casinos are Chinese, a 5\% appreciation in the value of the yuan probably would increase Adelson's company's earnings in that city by $\$ 73.8$ million per year. Governor Romney promised to call the Chinese government a currency manipulator, something President Obama had not done. See Alison Fitzgerald \& Julie Bykowicz, Donors Invest Millions in Romney for Billions in Return, BloOMBERG News, Aug. 29, 2012, http://www.bloomberg.com/news/201208-29/donors-invest-millions-in-romney-for-billions-in-returns.html.

428 See Thomas B. Edsall, Campaign Stops: Embracing Sheldon Adelson, N.Y. Times Blogs, Aug. $\quad$ 6, 2012, http://campaignstops.blogs.nytimes.com/2012/08/06/embracing-sheldonadelson/?nl=todaysheadlines\&emc=edit_th_20120806.

429 Sands Probed in Money Move, Wall St. J., Aug. 3, 2012, available at http://professional.wsj.com/article/SB1000087239639044432070457756680352112113 4.html?mod=WSJ_WSJ_US_News_5\&mg=reno64-wsj. The money-laundering investigation ended on August 27, 2013 when Las Vegas Sands entered an agreement with the U.S. Attorney's Office in Los Angeles to pay \$47 million to the federal government. See Michael Luo, Casino Settles in Money-Laundering Inquiry, NY TIMES, Aug. 28, 2013, at A16.

In 2001, Adelson was concerned that a congressional resolution opposing China's bid to host the 2008 Olympics would harm his business interests. He therefore telephoned a recipient of his campaign contributions, House majority whip Tom Delay. After investigating, Delay assured Adelson that the resolution was tied up in House procedures and "would never see the light of day." See In Thrall to Sheldon Adelson, N.Y. TIMES, Aug. 16, 2012, at A22; Connie Bruck, The Brass Ring: A Multibillionaire's Relentless Quest for Global Influence, THE NEW YORKER, June 30, 2008, http://www.newyorker.com/reporting/2008/06/30/080630fa_fact_bruck?currentPage=all

430 See Mike Allen, Sheldon Adelson: Inside the Mind of the Mega-Donor, PoliTiCO, Sept. 23, 2012, http://dyn.politico.com/printstory.cfm?uuid=A72CD8C543B8-437A-A8A4-B6F8BCE3CC6E. Adelson noted that someone-probably a government official-had leaked the fact that his company was under investigation only after he and his family had become heavily involved in the 2012 election. The object, he said, was "making me toxic so that they can make the argument to Republicans, 'This guy is toxic. Don't do business with him.'” Id. 
Romney were elected, Adelson would have a powerful ally on the two issues he cares most about: the security and prosperity of Israel, and opposition to unions, including the so-called card-check proposal that would make it easier for workers to organize." ${ }^{431}$ Las Vegas Sands owns the only non-union hotels and casinos on the Las Vegas strip. ${ }^{432}$

In addition, Adelson has begun a lobbying campaign for federal legislation to prohibit internet gambling. He opposes this gambling for "moral" reasons and also says that on-line gambling would be suicidal for the U.S. casino industry. Adelson told an interviewer that he is "willing to spend whatever it takes" to see the practice outlawed. ${ }^{433}$

Adelson does not believe his political contributions should be constitutionally protected or even legal. "I'm against very wealthy people attempting to or influencing elections," he told an interviewer. "But as long as it's doable I'm going to do it." ${ }^{334}$

Governor Romney lost the presidential election, and all but one of the other seven candidates Adelson supported in the 2012 general election lost too. Adelson, however, did not seem discouraged. He announced that he was prepared to double his donations the next time around and explained, "I happen to be in a unique business where winning and losing is the basis of the entire business. So I don't cry when I lose. There's always a new hand coming up." 435

Three days after Mitt Romney announced his choice of Paul Ryan to be his running mate, Ryan called on Adelson and other donors at Adelson's Venetian Hotel in Las Vegas. ${ }^{436}$ One week after the RomneyRyan ticket lost the general election, three Republicans then regarded as possible 2016 presidential contenders_-Governors Jindal of Louisiana,

${ }^{431} I d$.

432 See Dana Spitzer, Billionaire Casino Owner Adelson Takes Aim at Unions, PEOPLE's WORLD, Jan. 4, 2013, http://www.peoplesworld.org/billionaire-casino-owneradelson-takes-aim-at-unions/.

${ }^{433}$ See Nathan Vardi, Sheldon Adelson Says He is "Willing to Spend Whatever it Takes" to Stop Online Gambling, Forbes, Nov. 22, 2013, http://www.forbes.com/sites/nathanvardi/2013/11/22/sheldon-adelson-says-he-iswilling-to-spend-whatever-it-takes-to-stop-online-gambling/.

${ }^{434}$ Steven Bertoni, Billionaire Sheldon Adelson Says He Might Give \$100M to Newt Gingrich or Other Republican, Forbes.com, Feb. 21, 2012, available at http://www.forbes.com/sites/stevenbertoni/2012/02/21/billionaire-sheldon-adelson-sayshe-might-give-100m-to-newt-gingrich-or-other-republican/.

${ }^{435}$ See Alicia Mundy, Adelson to Keep Betting on the GOP, WALL St. J., Dec. 4, 2012, available at http://online.wsj.com/article/SB10001424127887323717004578159570568104706.html

${ }^{436}$ See Trip Gabriel, A Quiet Introduction to Big Money Donors, N.Y. TIMES, Aug. 16, 2012, at A12. 
Kasich of Ohio, and McDonnell of Virginia_-met privately with Adelson at the Venetian. ${ }^{437}$ On August 1, 2013, Adelson hosted a fundraiser at another of his Las Vegas resorts for the gubernatorial re-election of a fourth 2016 presidential possibility, Governor Christie of New Jersey. ${ }^{438}$

In March 2014, Adelson hosted a group called the Republican Jewish Coalition in Las Vegas. The gathering began with a dinner for another presidential prospect, former Governor Bush of Florida. Three possible presidential contenders, Governor Walker of Wisconsin and Governors Kasich and Christie, spoke later. Christie offended some listeners by referring to the West Bank as the "occupied territories" (a term also used on occasion by the U.S. State Department and Israeli officials), but the governor met privately with Adelson to say that he "misspoke." Some members of the press referred to the event as the "Sheldon primary." 439

437 See Kenneth P. Vogel, 2016 Contenders Court Mega-Donors, PoLiTiCO, Dec. 12, 2012, http://www.politico.com/story/2012/12/2016-contenders-courting-megadonors-84497.html.

438 See Maggie Haberman, Chris Christie at Sheldon Adelson Fundraiser in Las Vegas, POLITICO, Aug. 1, 2013, http://www.politico.com/story/2013/08/chris-christiesheldon-adelson-fundraiser-95085.html.

439 See Richard Miniter, Did Chris Christie “Bully” Sheldon Adelson's Friend?, FORBES, April 1, 2014, http://www.forbes.com/sites/richardminiter/2014/04/01/is-chrischristie-actually-electable/; Philip Rucker, Sheldon Adelson Plans VIP Dinner for Jeb Bush at GOP Gathering in Vegas, WASH. POST, March 22, 2014, http://www.washingtonpost.com/blogs/post-politics/wp/2014/03/22/sheldon-adelsonplans-vip-dinner-for-jeb-bush-at-gop-gathering-in-vegas/. 


\section{APPENDIX D}

\section{The EfFect of CAmpaign Dollars III: EXecutive Clemency}

The outcry that followed President Clinton's grant of 177 pardons and commutations on his last day in office focused particularly on the pardons he granted Marc Rich and his business partner Pincus Green. Rich and Green had been indicted on charges of trading with the enemy (conspiring to purchase more than six million barrels of oil from Iran while that nation was holding fifty-two U.S. hostages ${ }^{440}$ ) and tax evasion ("the biggest tax fraud case in the history of the United States," according to the chief prosecuting attorney ${ }^{441}$ ). Both had been fugitives and had lived in Switzerland since their indictments.

The Justice Department's rules barred the consideration of a fugitive's clemency application through ordinary channels, ${ }^{442}$ and White House Counsel Beth Nolan, Deputy Counsel Bruce Lindsey, and all the other lawyers in the White House Counsel's office opposed clemency. White House Chief of Staff John Podesta advised the President against clemency as well. ${ }^{443}$

Denise Rich, however, Marc Rich's former wife, had written two letters to the President requesting a pardon. "I am writing as a friend and admirer of yours to add my voice to the chorus of those who urge you to grant my former husband, Marc Rich, a pardon for the offenses unjustly alleged and so aggressively pursued," she wrote. ${ }^{444}$ Her earlier financial contributions had included "more than \$1 million to the Democratic Party and its candidates, $\$ 450,000$ to Clinton's library fund, $\$ 100,000$ to a fund to help Hillary Clinton's Senate campaign, $\$ 10,000$ to the President's defense fund, and \$7,375 worth of furniture to the Clintons." ${ }^{445}$

Denise Rich pressed a White House social secretary for an invitation to a dinner honoring recipients of the National Medal of the Arts and the National Humanities Medal. At this dinner, she sought a private moment with the President. According to Jack Quinn, a former Clinton White

440 See Eric Lichtblau \& Davan Maharaj, Sunday Report: Clinton Pardon of Rich a Saga of Power, Money and Influence, L.A. TIMES, Feb. 18, 2001, at A1.

441 The Controversial Pardon of International Fugitive Marc Rich: Hearings Before the H. Comm. on Government Reform, 107th Cong. at 88 (2001) (statement of Morris "Sandy" Weinberg, Jr., former assistant U.S. Attorney, Southern District of New York).

${ }^{442}$ See 28 C.F.R. § 1.2 (2012).

443 See Excerpts from Testimony on Pardon, N.Y. TIMES, Mar. 2, 2001, at A19 (testimony of John Podesta).

${ }^{444}$ See Alison Leigh Cowan, Rich Cashed in a World of Chits to Win Pardon, N.Y. Times, Apr. 11, 2001, at A1, A18.

445 James V. Grimaldi \& Dan Eggen, House Panel Expands Probe of Rich Pardon: 3 Former Clinton Aides Subpoenaed, WASH. Post, Feb. 16, 2001, at A3. 
House Counsel then representing Marc Rich, Denise Rich said simply, "I know you got my letter, and it means a great deal to me." 446

Beth Dozoretz also made a personal appeal to Clinton. She was a prominent Democratic fund-raiser, a former finance chair of the Democratic National Committee, and a friend of Denise Rich. ${ }^{447}$ President Clinton later wrote, “The suggestion that I granted the pardons because Mr. Rich's former wife, Denise, made political contributions and contributed to the Clinton library foundation is utterly false. There was absolutely no quid pro quo." 448

A less familiar tale of Clinton's magnanimity on his last day in office is almost as revealing. Carlos Vignali had served six years of a fifteenyear prison term when Clinton commuted his sentence to the time already served. According to the judge who sentenced Vignali, he was "one of the top two or three" of a group of thirty conspirators who had shipped about eight hundred pounds of cocaine from southern California to Minneapolis. ${ }^{449}$

Vignali's father, Horacio Vignali, had given $\$ 160,000$ in political contributions since his son's conviction, most of it to California Democrats. Horacio encouraged the recipients of these contributions and other prominent figures to endorse clemency for Carlos. He obtained letters or favorable phone calls from two members of Congress, two California State Assembly speakers, a cardinal of the Catholic Church, the Los Angeles County sheriff, a Los Angeles County Supervisor, a city councilman, and the United States Attorney in Los Angeles. ${ }^{450}$ Carlos's

446 Cowan, supra note, at A18.

447 See Melinda Henneberger, Pardon Puts New Spotlight on a Clinton FundRaiser, N.Y. TiMES, Feb. 17, 2001, at A12.

448 William Jefferson Clinton, Op-Ed, My Reasons for the Pardons, N.Y. TIMES, Feb. 18, 2001, at $\S 4$, at 13. For a fuller description of the Marc Rich and Pincus Green pardons, see Albert W. Alschuler, Bill Clinton's Parting Pardon Party, 100 J. CRIM. L. \& CRIM. 1131, 1137-42 (2010).

449 See David S. Doty, Clemency: A View from the Bench of Two CommutationsVignali and Willis, 13 FED. SENT’G REP. 161, 162 (2001). Judge Doty, who had written letters supporting the successful clemency applications of two other drug dealers he had sentenced, was "aghast" at the Vignali commutation. See Politics: Criminal Probe of Rich Pardon Opened: Other Developments, FACTS ON FILE WORD NEWS DiG., Feb. 14, 2001, at 100A2, available at LEXIS.

450 See Richard A. Serrano \& Stephen Braun, Working the American System, L.A. Times MAg., Apr. 29, 2001, at 10. The United States Attorney in Minneapolis, the district in which Carlos had been convicted, opposed clemency. See Margaret Colgate Love, The Pardon Paradox: Lessons of Clinton's Last Pardons, 32 CAP. U.L. REV. 185, 211 (2002). See also Alschuler, supra note , at 1143 (noting that Horatio Vignali paid fees of \$204,280 to Hugh Rodham, a Florida attorney and Hillary Clinton’s brother, to promote Carlos's cause in the White House but that Rodham returned the money at the behest of President and Mrs. Clinton after the press publicized the fees). 
clout-less co-conspirators collected no commutations, and several of them remained in custody when Carlos went home. ${ }^{451}$

John Catsimatidis, the owner of a supermarket chain, had been a contributor to both Democratic and Republican candidates and had been particularly supportive of the Clintons. He also had pledged to raise \$1 million for the Clinton Presidential Library. Catsimatidis wrote letters supporting the successful clemency applications of Edward Downe, Jr., a former Bear Stearns director who had pleaded guilty to tax and securities violations, ${ }^{452}$ and William Fugazy, the "limo king of New York" who had pleaded guilty to perjury. Catsimatidis then telephoned Clinton's Chief of Staff, John Podesta, to ask him to bring the letters to the President's attention. He told the press, “In the last 50 years, I don't know of anyone who's gotten a pardon who hasn't paid a lot of money to a lawyer or hasn't known somebody . . . . How do you create a pardon other than talking to people?"453

Republican as well as Democratic Presidents may have taken note of campaign contributions in deciding whether to grant clemency. Clinton's predecessor, George H. W. Bush, approved clemency at a far lower rate than any other twentieth-century American President, ${ }^{454}$ but he did pardon Armand Hammer, the Chairman of Occidental Petroleum, who recently had given $\$ 100,000$ to Republican state committees and another $\$ 100,000$ to the Bush-Quayle Inaugural Committee. ${ }^{455}$ Hammer had pleaded guilty 17 years earlier to making an illegal contribution to President Nixon's reelection campaign. ${ }^{456}$

451 See Richard A. Serrano \& Stephen Braun, In Many Drug Cases, Normal Clemency Process Bypassed, L.A. TIMES, Mar. 5, 2001, at A1 (reporting that Todd Hopson, a Vignali co-defendant serving eighteen years, "more closely fits the model that Clinton, FAMM [Families Against Mandatory Minimums] and others have spoken of - a first-time offender, a minor role in the drug crime, and someone who does not have the money or connections to get out of prison early").

452 Downe himself had contributed \$21,500 to Democratic candidates since 1991 and had given \$1000 to Hillary Clinton's Senate campaign. See David Lightman, Dodd Helped Friend Secure Presidential Pardon, HARTFORD COURANT, Feb. 24, 2001, at A11.

453 See Greg B. Smith, Clinton Library Fundraiser Helped Perjurer Get Pardon, WASH. POsT, Mar. 4, 2001, at A2.

454 See Office of the Pardon Attorney, U.S. Dep’t of Justice, Clemency Statistics, http://www.justice.gov/pardon/statistics.htm (last visited Sept. 30, 2013).

455 See Presidential Pardon Power: Hearings Before the Subcomm. on the COnstitution Of THE HOUSE COMM. ON THE JudiCiARY, 107th Cong., 1st Sess., at 8182 (2001) (statement of Member of Congress Jerrold Nadler); Joe Conason, The Bush Pardons, SALON.COM, Feb. 27, 2001, available at http://www.salon.com/news/col/cona/2001/02/27/pardons.

${ }^{456}$ Eric Pace, Armand Hammer Dies at 92; Executive Forged Soviet Ties, N.Y. TimES, Dec. 11, 1990, at A1; David Rampe, Armand Hammer Pardoned by Bush, N.Y. 
Bush also pardoned Edwin L. Cox, Jr., who had served a short prison sentence for bank fraud. After Bush's loss to Clinton in the 1992 Presidential election, former Texas governor Bill Clements called Bush's chief of staff, James Baker, to seek a pardon for Cox. Baker passed along Clements's request to the White House Counsel's office with a note reporting that Cox's father was “a longtime supporter of the President.” He sent a copy of his note to President Bush. After Bush approved the pardon, Cox's father continued his support by donating at least $\$ 100,000$ to the Bush Presidential Library, $\$ 125,000$ to Republican campaign committees, and $\$ 30,000$ to the gubernatorial campaign of President Bush's son, George W. Bush. ${ }^{457}$ Edwin Cox Jr. would have been ineligible for a pardon under the rules applicable to people without White House connections.

\section{APPENDIX E}

\section{The EFFECT OF CAMPAign DOLLARS IV: The APPOINTMENT OF AMBASSADORS}

In recently released post-Watergate testimony, former President Richard Nixon acknowledged that he reserved many ambassadorships for campaign contributors. "I did give top consideration to major financial contributors," he declared. 458 "It was not vitally important . . . to have . . . an individual whose qualifications were extraordinary" in positions like the U.S. ambassadorships to "Luxembourg or El Salvador or Trinidad et cetera." 459 "There was a lot of in-fighting within the Administration . . . as to ... how many posts would be available to financial contributors." 460

The former President pointed to tradition:

[I]n every presidency that I know of contributors have been appointed to non-career posts in considerable numbers. . . . Bill Bullitt, for example, was probably the best ambassador to

TIMEs, Aug. 15, 1989, available at http://www.nytimes.com/1989/08/15/us/armandhammer-pardoned-by-bush.html.

\begin{tabular}{ccccr}
\hline 457 & See Michael Weisskopf, A Pardon, a Presidential Library, a Big Donation, \\
Time, & Mar. & 6, & 2001, & available
\end{tabular} http://www.time.com/time/printout/0,8816,101652,00.html.

${ }^{458}$ Deposition of Richard M. Nixon at 35, United States v. Doe (Jan. 1974 grand jury investigation) (D.D.C.) (June 23, 1975) [hereinafter cited as Nixon Deposition], available at http://media.nara.gov/research/nixon-grand-jury/9-16a/9-16a-testimonynixon-6-23-1975-Part1.pdf.

${ }^{459} \mathrm{Id}$. at 18.

${ }^{460} \mathrm{Id}$. at 32 . 
Russia and the best ambassador to France we have had in a generation. Now he didn't get his job because he happened to shave the top of his head. He got his job because he contributed a half million dollars to Mr. Roosevelt's campaign. . . . Pearl Mesta wasn't sent to Luxembourg because she had big bosoms. Pearl Mesta went to Luxembourg because she made a good contribution. ${ }^{461}$

White House tapes that became public after Nixon testified show that he said to his chief of staff, H. R. Haldeman, "My point is that anybody who wants to be an ambassador must at least give \$250,000.” He said of Raymond Guest, who had expressed an interest in becoming ambassador to Belgium, "Uh, he's fine. His wife speaks French, he speaks French, uh, uh, but the cost is uh, a quarter million." On being told of a press report that Cornelius Vanderbilt Whitney would be named ambassador to Spain (something that Nixon apparently did not know), he declared, "Hell, if we did it, it was a great sale. He gave a quarter of a million dollars." 462

${ }^{461}$ Id. at 21, 25-26. Perle Mesta, a famed Washington hostess and Harry Truman's ambassador to Luxembourg, inspired the Irving Berlin musical "Call Me Madam." She was portrayed on stage and screen by Ethel Merman. Perle Mesta, WIKIPEDIA, http://en.wikipedia.org/wiki/Perle_Mesta (last visited Dec. 15, 2011).

Mesta's name was almost never mentioned without the tag line "the hostess with the mostest," and William Bullitt might have been the host with the most. His career was even more colorful than Mesta's. It included co-authoring a psycho-biography of Woodrow Wilson with Sigmund Freud (who had personally psychoanalyzed Bullitt), serving as the first American ambassador to the Soviet Union, conducting a back-door campaign to have Sumner Welles dismissed from the State Department because Welles had solicited gay sex from Pullman porters, and hosting at his Moscow residence "the Spring Ball of the Full Moon,” a 1935 party at which more than 100 zebra finches flew throughout the house and a baby bear got drunk on champagne fed to it by Communist leader Karl Radek. William Christian Bullitt, Jr., WIKIPEDIA, http://en.wikipedia.org/wiki/William_Christian_Bullitt,_Jr. (last visited Dec. 15, 2011).

${ }^{462}$ See George Lardner, Jr. \& Walter Pincus, Nixon Set Minimum Contribution for Choice Diplomatic Posts, WASH. Post, Oct. 30, 1997, at A19. After Thomas Pappas raised funds that Nixon knew would be paid to the Watergate burglars for their silence, Nixon agreed to Pappas's request that he not replace the ambassador to Greece. "Let him stay," the President said of the ambassador. "Let him stay. No problem. Pappas has raised the money we need for this other activity." See George Lardner, Jr. \& Walter Pincus, Contributor Got Oval Office Thank-You for Watergate Funds, WASH. Post, Oct. 30, 1997, at A19.

Nixon acknowledged that "the making of an absolute commitment for ambassadorships” would be illegal. Nixon Deposition at 37. Prosecutors sought his testimony because some of his aides apparently had made such absolute commitments. Notably, two campaign contributors who had obtained ambassadorships in Nixon's first term apparently had been promised that he would appoint them to better (i.e., European) 
The custom of giving campaign contributors a large leg up in obtaining ambassadorships has not faded in the years since the Nixon administration. In the administration of President Barack Obama, as in those of his predecessors George W. Bush, Bill Clinton, George H. W. Bush, Ronald Reagan, and Jimmy Carter, slightly more than 30\% of all ambassadors have been political appointees. ${ }^{463}$ The cost of a top ambassadorship apparently has increased, however, from \$250,000 to \$1 million. ${ }^{464}$

ambassadorships if each gave $\$ 100,000$ to his re-election campaign. Nixon’s personal lawyer, Herbert Kalmbach, in fact went to prison for making this arrangement with the ambassador to Trinidad and Tobago, Fife Symington, Jr. See Bob Woodward \& Carl Bernstein, Haldeman Role in Envoy Deal Told, WASH. Post, June 26, 1974, at A1. See generally Final RePORT OF THE SELECt COMMITTEe on PRESIDENTIAL CAMPAign ACtivities, 93d Cong., 2d Sess., at 492-510 (1974) (compiling extensive evidence of the influence of campaign contributions on President Nixon's ambassadorial appointments).

463 See Al Kamen, Embassy Openings for Open Wallets, WASH. Post, Jan. 19, 2011, at A13. See also Brandon Conradis, Obama Selects Key Donor as Ambassador to Hungary, Open Secrets Blog, Nov. 8, 2013, http://www.opensecrets.org/news/2013/11/obama-selects-key-donor-as-ambassad.html; Michael Beckel, Big Donors and Bundlers Among Obama's Ambassador Picks, Open Secrets Blog, May 28, 2009, http://www.opensecrets.org/news/2009/05/big-donorsbundlers-among-obam.html; Michael Beckel, Obama's New Ambassador Nominees Gave Big-And Bundled Bigger, Open Secrets Blog, June 18, 2009, http://www.opensecrets.org/news/2009/06/obamas-new-ambassador-nominees.html.

${ }^{464}$ See Kamen, supra note. 


\section{APPENDIX F}

\section{PARTISAN AdVANTAgE AND INCUMBENT PROTECTION}

The plurality wrote in McCutcheon, "[T] hose who govern should be the last people to help decide who should govern." ${ }^{465}$ The last people who should have a job, however, may be the ones to whom the Constitution assigns it. Sadly perhaps, legislators are the only people who can supply election laws. Under the "rule of necessity," even a judge with a financial interest in the outcome of a case may hear it when no disinterested judge can replace him. ${ }^{466}$

When legislators enact campaign finance regulations, they influence the outcome of elections, and when judges strike down campaign finance regulations, they do too. Because members of Congress must stand for reelection, there is good reason for mistrusting their decisions. The Supreme Court's partisan division on the validity of campaign finance regulations raises eyebrows too. 467

Considerable discussion has focused on whether contribution limits benefit incumbents (because challengers can overcome the electoral advantages of incumbents only by raising vast sums) or challengers benefit (because incumbents can more easily raise vast sums). In Randall v. Sorrell, ${ }^{468}$ the Supreme Court saw low contribution limits as a form of incumbent protection. It invalidated Vermont's extremely low limits partly because they threatened to "harm the electoral process by preventing challengers from mounting effective campaigns against incumbent officeholders." 469 But the Court apparently got it backwards. Recent empirical studies have concluded that "[i]n real world elections, the benefits of low contribution limits largely redound to challengers." 470

Generalizations on this subject are of dubious value. Contribution limits plainly benefit some incumbents and plainly disadvantage others.

${ }^{465}$ McCutcheon v. FEC, 134 S. Ct. 1434,1442-43 (2014) (emphasis in the original).

${ }^{466}$ See United States v. Will, 449 U.S. 200 (1980).

${ }^{467}$ Moreover, Bush v. Gore, 31 U.S. 98 (2000), still casts a shadow.

468548 U.S. 230 (2006).

${ }^{469}$ Id. at 248-49.

470 Clara Torres-Spelliscy, Kahlil Williams, \& Thomas Stratmann, ELECTORAL COMPETITION AND LOW CONTRIBUTION LiMITS 2 (Brennan Center for Justice 2009), available

http://www.brennancenter.org/sites/default/files/legacy/publications/Electoral.Competiti on.pdf. See Thomas Stratmann, Do Low Contribution Limits Insulate Incumbents from Competition?, 9 ELECTION L.J. 125, 125, 126-27 (2010) (describing prior studies and offering further findings that "[t]he tighter the [contribution] limits, the more competitive the election”). 
An incumbent from a "swing" district who expects wealthy donors to target him at the next election would be likely support contribution limits with enthusiasm. An incumbent who has been reelected repeatedly from a safe district, however, would be likely to oppose them. This member's seniority and the power accompanying it could enable him to fill a large war chest, which he would not need to use to wage war. Whether progressive or conservative, this incumbent might use most of the funds he collected to aid other politicians and to pay the expenses of campaigning and office holding-including expenses he might incur at the National Democratic Club or the Capitol Hill Club and at five-star resorts. This member would have little to gain by voting to limit contributions. $^{471}$

A less discussed, more easily answered, and probably more relevant question is which political party benefits from contribution limits. When one party tends to attract small donors and the other large donors, capping contributions is likely to benefit the party that disproportionately attracts small donors. Today the party that benefits politically from contribution limits is almost certainly the Democratic Party. ${ }^{472}$

471 Since 1989, federal law has prohibited federal office holders, former office holders, and current candidates from using campaign funds to pay personal living expenses. See U.S. Senate, Select Committee on Ethics, Senate Ethics Manual 154 n.428 (2003). Candidates and former candidates, however, may donate these funds to charities without limit, to political parties without limit, and to political campaigns other than their own within limits. They also may use campaign funds to pay legal expenses if charged with official misconduct, to buy furniture and art for their offices, and to pay other expenses of campaigning and office holding. Id. at 154-55. Officials have used these funds to enable their spouses to accompany them on work-related travel and to host extended fund-raising gatherings at resorts in places like Vail, Park City, Puerto Rico, Las Vegas, South Florida, and Bermuda. One member of Congress even has used campaign funds to pay herself $18 \%$ interest on loans from herself to her campaign. See 60 Minutes: Washington's Open Secret: Profitable PACs (C.B.S. Television, Oct. 20, 2013), http://www.cbsnews.com/8301-18560_16257608255/washingtons-open-secret-profitable-pacs/; Eric Lipton, A Loophole Allows Lawmakers to Reel in Trips and Donations, N.Y. TIMES, Jan. 20, 2014, at A1; Ken Silverstein, Beltway Bacchanal: Congress Lives High on the Contributor's Dime, HARPER's MAGAzINE, Mar. 2008, at 47; Dave Mann \& Abby Rapoport, Lifestyles of the Corrupt and Elected: How Do Texas Legislators Live Large on their $\$ 7200$ Salaries? Campaign Funds Pay for Lavish Perks and Personal Expenses, Courtesy of Special Interests, THE TEXAS OBSERVER, Jan. 16, 2011, available at http://www.texasobserver.ord/cover-story/lifestyles-of-the-corrupt-and-elected; Thomas J. Cole, Lawmakers Use Campaign Funds for Expenses, AlBUQUERQUE JOURNAL, Feb. 15, 2012, at A1; Adam Schwartzman, Joe Bruno, Other Pols Use Campaign Funds to Pay Legal Expenses, Village Voice Blogs, Sep. 3, 2010, available at http://blogs.villagevoice.com/runninscared/2010/09/joe bruno_other.php.

472 In 2012, the Barack Obama presidential campaign raised three times more cash from "small individual contributors" than the Mitt Romney presidential campaign. It 
It may not be a coincidence that the five majority justices in both Citizens United and McCutcheon were appointed by Republican presidents while three of the four dissenters in Citizens United and all of the dissenters in McCutcheon were appointed by Democrats. To explain this alignment, one need not embrace the cynical view that Republican justices strive to get Republicans elected. Instead, Republican-appointed justices might simply have been more suspicious than Democratappointed justices of legislators whose approval of campaign-finance limitations could have furthered their own partisan interests. Without seeking to tilt the game board in favor of their party, these justices might have sought to block Democratic legislators from tilting it in favor of theirs.

Undoubtedly legislators of both parties do consider the electoral consequences of campaign finance restrictions, and their efforts to gain electoral advantage should lead judges to be wary. Wariness goes too far,

raised only 1.3 times more cash from "large individual contributors.” See Center For Responsive Politics, OpenSecrets.org, 2012 Presidential Race, http://www.opensecrets.org/pres12/index.php (last visited Nov. 9, 2013).

In the 2010 midterm elections, conservative super PACs outspent liberal super PACs by 25 percent. See Michael Beckel, Led by Karl Rove-Linked Groups, "Super PACs” and Nonprofits Significantly Aid GOP in Election 2010, OpenSecretsblog, Nov. 5, 1010, http://www.opensecrets.org/news/2010/11/led-by-karl-rove-linked-groupsnonp.html.

According to the New York Times,

In the first seven weeks of 2012, about two dozen individuals, couples or corporations gave $\$ 1$ million or more to Republican super PACs. Collectively, their contributions totaled more than \$50 million, making them easily the most influential and powerful political donors in politics today. They have relatively few Democratic counterparts so far . . . .

Campaign Finance (Super PACs), TIMES TOPICS, Sept. 13, 2012, http://topics.nytimes.com/top/reference/timestopics/subjects/c/campaign_finance/index. html.

A Times update in late September 2012 reported:

While Democratic super PACs have begun to attract a growing number of donors giving six- and seven-figure checks, they remain far behind their Republican equivalents in terms of fund-raising. The four top Democratic groups had together raised less through the beginning of September than Restore Our Future, which is backing Mitt Romney.

Nicholas Confessore, Reversing Course, Soros Gives \$1 Million to a Pro-Obama “Super PAC”, N.Y. TIMES CAUCUS, Sept. 27, 2012, http://thecaucus.blogs.nytimes.com/2012/09/27/soros-gives-1-million-to-democraticsuper-pac/?src=recg. 
[August 27, 2014]

however, when it causes judges to turn a blind eye to the contributions that make deliberate favoritism in the award of government benefits likely. 
Readers with comments may address them to:

Professor Emeritus Albert W. Alschuler University of Chicago Law School

1111 East 60th Street

Chicago, IL 60637

a-alschuler@law.northwestern.edu 


\section{The University of Chicago Law School Public Law and Legal Theory Working Paper Series}

For a listing of papers 1-400 please go to http://www.law.uchicago.edu/publications/papers/publiclaw.

401. Gary Becker, François Ewald, and Bernard Harcourt, "Becker on Ewald on Foucault on Becker” American Neoliberalism and Michel Foucauilt’s 1979 Birth of Biopolitics Lectures, September 2012

402. M. Todd Henderson, Voice versus Exit in Health Care Policy, October 2012

403. Aziz Z. Huq, Enforcing (but Not Defending) “Unconstitutional” Laws, October 2012

404. Lee Anne Fennell, Resource Access Costs, October 2012

405. Brian Leiter, Legal Realisms, Old and New, October 2012

406. Tom Ginsburg, Daniel Lnasberg-Rodriguez, and Mila Versteeg, When to Overthrow Your Government: The Right to Resist in the World's Constitutions, November 2012

407. Brian Leiter and Alex Langlinais, The Methodology of Legal Philosophy, November 2012

408. Alison L. LaCroix, The Lawyer's Library in the Early American Republic, November 2012

409. Alison L. LaCroix, Eavesdropping on the Vox Populi, November 2012

410. Alison L. LaCroix, On Being “Bound Thereby,” November 2012

411. Alison L. LaCroix, What If Madison had Won? Imagining a Constitution World of Legislative Supremacy, November 2012

412. Jonathan S. Masur and Eric A. Posner, Unemployment and Regulatory Policy, December 2012

413. Alison LaCroix, Historical Gloss: A Primer, January 2013

414. Jennifer Nou, Agency Self-Insulation under Presidential Review, January 2013

415. Aziz Z. Huq, Removal as a Political Question, February 2013

416. Adam B. Cox and Thomas J. Miles, Policing Immigration, February 2013

417. Anup Malani and Jonathan S. Masur, Raising the Stakes in Patent Cases, February 2013

418. Ariel Porat and Lior Strahilevits, Personalizing Default Rules and Disclosure with Big

Data, February 2013

419. Douglas G. Baird and Anthony J. Casey, Bankruptcy Step Zero, February 2013

420. Alison L. LaCroix, The Interbellum Constitution and the Spending Power, March 2013

421. Lior Jacob Strahilevitz, Toward a Positive Theory of Privacy Law, March 2013

422. Eric A. Posner and Adrian Vermeule, Inside or Outside the System? March 2013

423. Nicholas G. Stephanopoulos, The Consequences of Consequentialist Criteria, March 2013

424. Aziz Z. Huq, The Social Production of National Security, March 2013

425. Aziz Z. Huq, Federalism, Liberty, and Risk in NIFB v. Sebelius, April 2013

426. Lee Anne Fennell, Property in Housing, April 2013

427. Lee Anne Fennell, Crowdsourcing Land Use, April 2013

428. William H. J. Hubbard, An Empiritcal Study of the Effect of Shady Grove v. Allstate on Forum Shopping in the New York Courts, May 2013

429. Daniel Abebe and Aziz Z. Huq, Foreign Affairs Federalism: A Revisionist Approach, May 2013

430. Albert W. Alschuler, Lafler and Frye: Two Small Band-Aids for a Festering Wound, June 2013

431. Tom Ginsburg, Jonathan S. Masur, and Richard H. McAdams, Libertarian Paternalism, Path Dependence, and Temporary Law, June 2013

432. Aziz Z. Huq, Tiers of Scrutiny in Enumerated Powers Jurisprudence, June 2013 
433. Bernard Harcourt, Beccaria's On Crimes and Punishments: A Mirror of the History of the Foundations of Modern Criminal Law, July 2013

434. Zachary Elkins, Tom Ginsburg, and Beth Simmons, Getting to Rights: Treaty

Ratification, Constitutional Convergence, and Human Rights Practice, July 2013

435. Christopher Buccafusco and Jonathan S. Masur, Innovation and Incarceration: An Economic Analysis of Criminal Intellectual Property Law, July 2013

436. Rosalind Dixon and Tom Ginsburg, The South African Constitutional Court and SocioEconomic Rights as 'Insurance Swaps', August 2013

437. Bernard E. Harcourt, The Collapse of the Harm Principle Redux: On Same-Sex Marriage, the Supreme Court's Opinion in United States v. Windsor, John Stuart Mill's essay On Liberty (1859), and H.L.A. Hart’s Modern Harm Principle, August 2013

438. Brian Leiter, Nietzsche against the Philosophical Canon, April 2013

439. Sital Kalantry, Women in Prison in Argentina: Causes, Conditions, and Consequences, May 2013

440. Becker and Foucault on Crime and Punishment, A Conversation with Gary Becker, François Ewald, and Bernard Harcourt: The Second Session, September 2013

441. Daniel Abebe, One Voice or Many? The Political Question Doctrine and Acoustic Dissonance in Foreign Affairs, September 2013

442. Brian Leiter, Why Legal Positivism (Again)? September 2013

443. Nicholas Stephanopoulos, Elections and Alignment, September 2013

444. Elizabeth Chorvat, Taxation and Liquidity: Evidence from Retirement Savings, September 2013

445. Elizabeth Chorvat, Looking Through' Corporate Expatriations for Buried Intangibles, September 2013

446. William H. J. Hubbard, A Theory of Pleading, Litigation, and Settlement, November 2013

447. Tom Ginsburg, Nick Foti, and Daniel Rockmore, "We the Peoples”: The Global Origins of Constitutional Preambles, March 2014

448. Lee Anne Fennell and Eduardo M. Peñalver, Exactions Creep, December 2013

449. Lee Anne Fennell, Forcings, December 2013

450. Jose Antonio Cheibub, Zachary Elkins, and Tom Ginsburg, Beyond Presidentialism and Parliamentarism, December 2013

451. Nicholas Stephanopoulos, The South after Shelby County, October 2013

452. Lisa Bernstein, Trade Usage in the Courts: The Flawed Conceptual and Evidentiary Basis of Article 2's Incorporation Strategy, November 2013

453. Tom Ginsburg, Political Constraints on International Courts, December 2013

454. Roger Allan Ford, Patent Invalidity versus Noninfringement, December 2013

455. M. Todd Henderson and William H.J. Hubbard, Do Judges Follow the Law? An Empirical Test of Congressional Control over Judicial Behavior, January 2014

456. Aziz Z. Huq, Does the Logic of Collective Action Explain Federalism Doctrine? January 2014

457. Alison L. LaCroix, The Shadow Powers of Article I, January 2014

458. Eric A. Posner and Alan O. Sykes, Voting Rules in International Organizations, January 2014

459. John Rappaport, Second-Order Regulation of Law Enforcement, April 2014

460. Nuno Garoupa and Tom Ginsburg, Judicial Roles in Nonjudicial Functions, February 2014

461. Aziz Huq, Standing for the Structural Constitution, February 2014

462. Jennifer Nou, Sub-regulating Elections, February 2014

463. Albert W. Alschuler, Terrible Tools for Prosecutors: Notes on Senator Leahy's Proposal to "Fix" Skilling v. United States, February 2014 
464. Aziz Z. Huq, Libertarian Separation of Powers, February 2014

465. Brian Leiter, Preface to the Paperback Edition of Why Tolerate Religion? February 2014

466. Jonathan S. Masur and Lisa Larrimore Ouellette, Deference Mistakes, March 2014

467. Eric A. Posner, Martii Koskenniemi on Human Rights: An Empirical Perspective, March 2014

468. Tom Ginsburg and Alberto Simpser, Introduction, chapter 1 of Constitutions in Authoritarian Regimes, April 2014

469. Aziz Z. Huq, Habeas and the Roberts Court, April 2014

470. Aziz Z. Huq, The Function of Article V, April 2014

471. Aziz Z. Huq, Coasean Bargaining over the Structural Constitution, April 2014

472. Tom Ginsburg and James Melton, Does the Constitutional Amendment Rule Matter at All? Amendment Cultures and the Challenges of Measuring Amendment Difficulty, May 2014

473. Eric A. Posner and E. Glen Weyl, Cost-Benefit Analysis of Financial Regulations: A Response to Criticisms, May 2014

474. Paige A. Epstein, Addressing Minority Vote Dilution Through State Voting Rights Acts, February 2014

475. William Baude, Zombie Federalism, April 2014

476. Albert W. Alschuler, Regarding Re’s Revisionism: Notes on "The Due Process Exclusionary Rule", May 2014

477. Dawood I. Ahmed and Tom Ginsburg, Constitutional Islamization and Human Rights: The Surprising Origin and Spread of Islamic Supremacy in Constitutions, May 2014

478. David Weisbach, Distributionally-Weighted Cost Benefit Analysis: Welfare Economics Meets Organizational Design, June 2014

479. William H. J. Hubbard, Nuisance Suits, June 2014

480. Saul Levmore and Ariel Porat, Credible Threats, July 2014

481. Brian Leiter, The Case Against Free Speech, June 2014

482. Brian Leiter, Marx, Law, Ideology, Legal Positivism, July 2014

483. John Rappaport, Unbundling Criminal Trial Rights, August 2014

484. Daniel Abebe, Egypt, Ethiopia, and the Nile: The Economics of International Water Law, August 2014

485. Albert W. Alschuler, Limiting Political Contributions after Mccutcheon, Citizens United, and SpeechNow, August 2014 